\title{
Distribution of major and trace elements in the Kovin lignite (Serbia)
}

\author{
Dragana Životić ${ }^{1}$, Olga Cvetković ${ }^{2}$, Predrag Vulić ${ }^{1}$, Ivan Gržetić ${ }^{3}$, Vladimir Simić ${ }^{1}$, Konstantin Ilijević ${ }^{3}$, \\ Biljana Dojčinović ${ }^{2}$, Suzana Erić ${ }^{2}$, Bogdan Radić ${ }^{4}$, Sanja Stojadinović ${ }^{2}$ and Snežana Trifunović ${ }^{3}$
}

\author{
${ }^{1}$ University of Belgrade, Faculty of Mining and Geology, Đušina 7, 11000 Belgrade, Serbia; (corresponding author: dragana.zivotic@rgf.bg.ac.rs; \\ tel: +381 113219 251; fax: +381 113235 537) \\ ${ }^{2}$ Center of Chemistry, IChTM, Studentski trg 12-16, 11000 Belgrade, Serbia \\ ${ }^{3}$ University of Belgrade, Faculty of Chemistry, Studentski trg 12-16, 11000 Belgrade, Serbia \\ ${ }^{4}$ Kovin coal mine, Cara Lazara 85, 26220 Kovin, Serbia
}

doi: $10.4154 / g c .2019 .06$

Article history:

Received June 08, 2018

Revised manuscript accepted December 12, 2018

Available online February 15, 2019

Keywords: Kovin deposit, lignites, major and trace elements, mineral composition

\begin{abstract}
A geochemical and mineralogical study was performed on lignite samples from the Upper Miocene Kovin deposit, hosting three coal seams. The Kovin lignite is characterized by high moisture content, medium to high ash yield, medium to high sulphur content and a relatively low gross and net calorific value. The mineralogical composition, and major and trace element contents were determined by X-ray diffraction, scanning electron microscopy with energy dispersive Xray spectroscopy (SEM-EDS) analyses, and inductively coupled plasma optical emission spectrometry (ICP-OES). The most abundant minerals in all lignite samples from the three coal seams are clays (illite/smectite), silicates (quartz, plagioclase), sulphates (gypsum/anhydrite) and carbonate (calcite). The other iron-rich minerals are sulphides, oxides and hydroxides (pyrite, magnetite, haematite, and limonite). In general, mineral matter in the matrix coal consists of illite/ smectite and quartz, while xylite-rich coals, apart from illite/smectite, have a higher content of sulphates and Fe-oxide/hydroxide minerals. The lignite from the Kovin deposit is enriched in As, $\mathrm{Cd}$, Co, Cr, Cu, Ga, Li, Mn, Mo, Ni, Pb, V, Zn, Gd, Tb, Er and Lu in comparison with the Clarke values for brown coals. The statistical analysis of bulk compositional data shows inorganic affinity for the majority of the major and trace elements and possible association with pyrite, illite/ smectite and calcite.
\end{abstract}

\section{INTRODUCTION}

Lignites of Upper Miocene age are the most important energy source in Serbia. Almost all lignite production (90\%) from the Kolubara and Kostolac basins is used in thermal power plants (TPP), (EPS, 2018). Information on the content, distribution and mode of occurrence of major and trace elements, especially potentially toxic and radioactive ones, are of great importance, if coal is used for combustion in a TPP. Many studies of trace elements contained in coal have been carried out in order to understand and evaluate their mode of occurrence, as well as their behaviour during combustion (e.g., DAVIDSON, 2000; FINKELMAN et al., 2018; MEIJ, 1995; SWAINE, 1990; SWAINE \& GOODARZI, 1995; WARD, 2016; YUDOVICH, 1978; YUDOVICH et al., 1985; YUDOVICH \& KETRIS, 2002, 2005b). The mode or form of occurrence of trace elements may control potential hazardous effects to human health (FINKELMAN et al., 2002) and the environment. Numerous studies performed in SE Europe on Greek (CHATZIAPOSTOLOU et al., 2006; GENTZIS et al., 1996, 1997; GEORGAKOPOULOS, 2001; FILIPPIDIS et al., 1996; FOSCOLOS et al., 1998; KOUKOUZAS et al., 2010), Bulgarian (KOSTOVA \& ZDRAVKOV, 2007; VASSILEV \& VASILEVA, 1998, 2009; VASSILEV et al., 2001, 2009; VASSILEVA \& VASSILEV, 2005) and Turkish lignites (GÜRDAL, 2011; KARAYIGIT \& GAYER, 2000; KARAYIGIT et al., 2000; 2001; PALMER et al., 2004; SUTCU \& KARAYIGIT, 2015; VASSILEV et al., 2005) of similar age and rank as the Kovin lignite, have focused on the mineral matter and major and trace elements contents.
The Upper Miocene Kovin lignite deposit is located about $50 \mathrm{~km}$ east of Belgrade (Fig. 1). Together with the Kostolac basin, it is a part of the unique coal basin separated by the Danube River (MITROVIĆ et al., 2016), which forms the southern boundary of the Kovin deposit. The Kovin deposit is divided into two fields: the western field "A", and the eastern field "B", $16.3 \mathrm{~km}^{2}$ and 23.7 $\mathrm{km}^{2}$, in areal extent respectively. According to the Geological report of the Kovin deposit, the lignite resources and reserves are currently estimated at $275 \mathrm{Mt}$ (MITROVIĆ et al., 2016). Subaqueous exploitation of lignite (below the Danube river) in the offshore zone of the "A" field, named "Experimental exploitation field" (EEF) began in 1991, and is still active. Since 1991, the Kovin mine has produced about $5 \mathrm{Mt}$ of lignite, with an annual production of $\sim 300,000 \mathrm{t}$.

Geological exploration of the wider area of the Kovin deposit, including the Kostolac coal basin, began in the late $19^{\text {th }}$ century. The Upper Miocene (Pontian) age of the coal-bearing sediments was confirmed by palaeontological studies (PAVLOVIĆ, 1959; SPAJIĆ-MILETIĆ, 1960, 1969; STEVANOVIĆ, 1951). The distribution of palynomorph assemblages in the lignite from the EEF field (MILIVOJEVIĆ \& ŽIVOTIĆ, 2006; ŽIVOTIĆ et al., 2007) suggests that decay-resistant gymnosperm (coniferous) trees and bushes played an important role in lignite formation. Previous petrographic investigations (ERCEGOVAC et al., 2006; ŽIVOTIĆ et al., 2005, 2007) performed on samples from several boreholes from the I and II coal seam, showed that the lignite from the Kovin deposit is a typical humic coal with variable huminite, liptinite and inertinite contents, and a mean ran- 
ฮ dom huminite reflectance of $0.30 \pm 0.03$ (ERCEGOVAC et al., 2006). Recent petrographic and organic geochemical investigations (MITROVIĆ et al., 2016, 2017) confirm the variation in maceral and lithotype composition in both fields and all three seams with diagenetic alteration governed by chemoautotrophic-, methanotrophic- and heterotrophic bacteria. The same samples were used to determine the content and distribution of major and trace elements in the coal.

The aim of this study is to present the content and mode of occurrence of major and trace elements in coal from the Kovin deposit in order to assess their behaviour in case of exploitation for electric power generation.

\section{GEOLOGICAL SETTINGS}

The area of the Kovin deposit consists of Palaeozoic schist, Tertiary and Quaternary sediments (Fig. 1). The basement of the Kovin deposit is formed of Devonian low-grade schist overlain by Neogene sediments.

The Kovin deposit together with the Kostolac basin was formed in the Pannonian Basin System in shallow lacustrine, delta plain and fluvial environments. During the late Miocene it became increasingly widespread as Lake Pannon (e.g. MAGYAR et al., 1999, 2013; SZTANÓ et al., 2013) filled with coal-bearing sediments in the central part of Serbia. The total thickness of Neogene sediments is estimated at $1000 \mathrm{~m}$. The Neogene units of the Kovin deposit

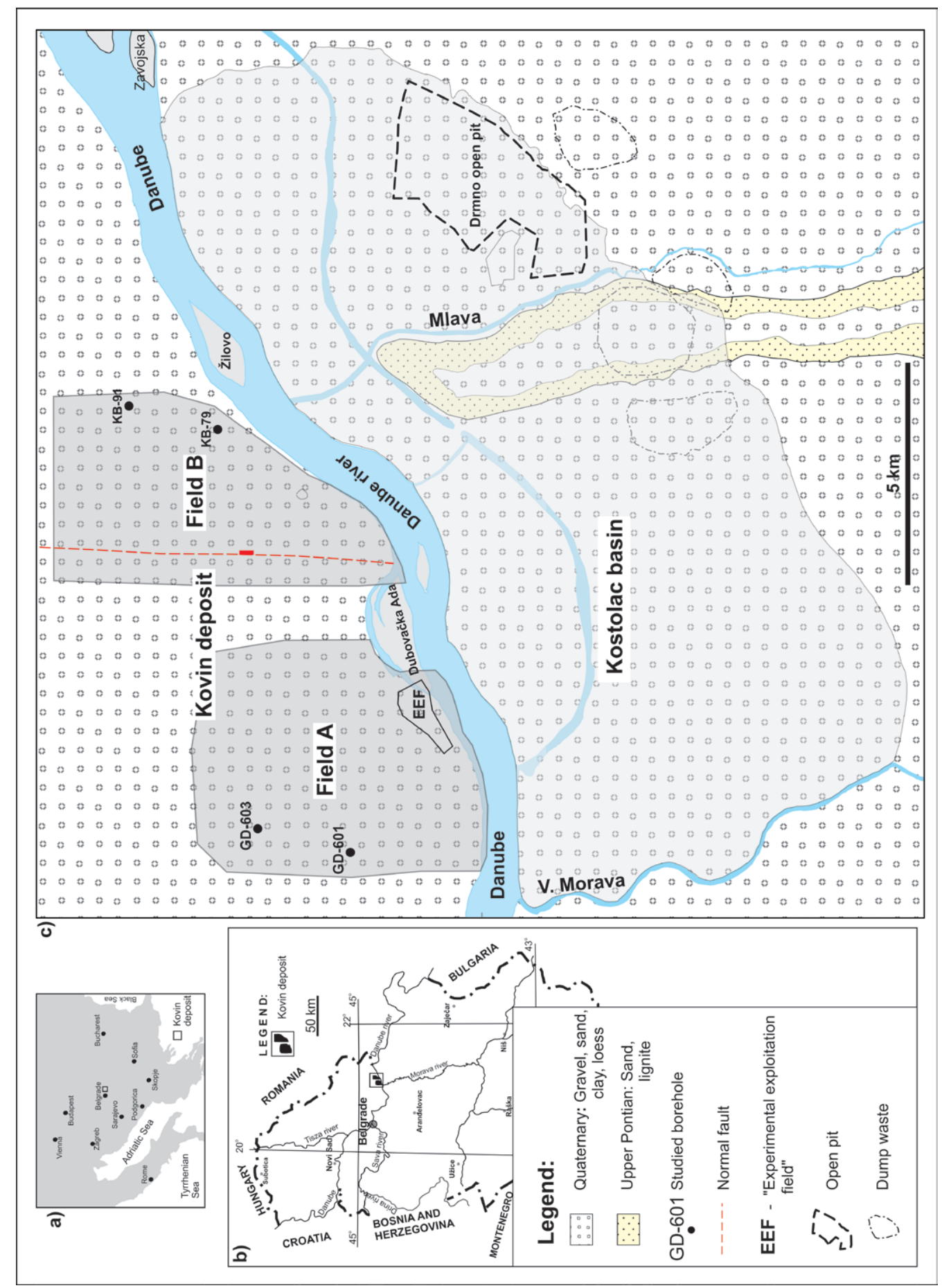

Figure 1. Location of the Kovin deposit (a, b) and simplified geological map (c) of the Kovin deposit with sample locations (modified after Basic Geologic Map of Serbia, section L34-127 and L34-115; http://geoliss.mre.gov.rs/OGK/RasterSrbija/). 
Table 1. The maceral composition (vol.\%, mmf.) after MITROVIĆ et al. (2016)

\begin{tabular}{|c|c|c|c|c|c|c|}
\hline \multirow{2}{*}{ Subgroup/group } & \multicolumn{2}{|c|}{ I seam } & \multicolumn{2}{|c|}{ II seam } & \multicolumn{2}{|c|}{ III seam } \\
\hline & Min-Max & $\bar{x}$ & Min-Max & $\bar{x}$ & Min-Max & $\bar{x}$ \\
\hline Telohuminite & $20.23-65.52$ & 45.67 & $29.96-72.01$ & 45.57 & $18.49-61.18$ & 36.12 \\
\hline Detrohuminite & $17.19-66.02$ & 35.94 & $14.43-49.34$ & 36.25 & $18.61-66.00$ & 39.39 \\
\hline Gelohuminite & $3.50-12.86$ & 7.77 & $2.68-12.54$ & 7.66 & $5.76-13.96$ & 9.07 \\
\hline HUMINITE & $81.41-95.05$ & 89.38 & $81.45-95.03$ & 89.48 & $74.49-94.87$ & 84.58 \\
\hline LIPTINITE & $2.04-7.06$ & 4.30 & $2.98-7.44$ & 4.84 & $1.13-4.86$ & 3.32 \\
\hline INERTINITE & $2.03-14.82$ & 6.32 & $1.99-14.03$ & 5.68 & $1.64-24.38$ & 12.10 \\
\hline
\end{tabular}

Min - minimum; Max - maximum; $\bar{X}$ - arithmetic mean value; $\mathrm{mmf}$ - Mineral matter free basis.

consist of: a) Sarmatian (Middle Miocene) shallow brackish-marine sediments; b) Pannonian (Late Miocene) marly sediments; c) Pontian (Late Miocene; RÖGL, 1996) shallow, caspi-brackish to fresh water sediments; d) Lower Pliocene fresh water clastic sediments, as described in detail in MITROVIĆ et al. (2016).

In the Upper Miocene (Pontian) clastic coal-bearing series of the Kovin deposit, three coal seams are hosted (MITROVIĆ et al., 2016) namely III (the oldest), II and I (the youngest). Seam III was found in the eastern part of the B field with a total thickness from a few to 48.7 metres (including interbedded waste rock). Coal seam II developed through the entire Kovin deposit, and in the eastern part it is uniform, but towards the west it splits into several coal layers. Total seam thickness is variable, up to 7 $\mathrm{m}$. The youngest, coal seam I has been explored in the southern part of the A field (EEF; Fig. 1). In the B field and the eastern, south-eastern and south part of the A field, it is more or less uniform, but towards the north-west it splits into two coal layers (upper-Ia and lower-Ib) with a total thickness of up to $15 \mathrm{~m}$.

Tectonic features of the Pontian sediments are relatively uniform in the major part of the deposit; coal seams dip at low angles $\left(5-7^{\circ}\right)$ to the northwest. In the central part of deposit coal seams form an antiform due to post-sedimentary faulting, causing erosion of coal seam I in the central part of the deposit between fields $\mathrm{A}$ and $\mathrm{B}$. One of the most important normal faults is located in the western part of the B field (Fig. 1).

\section{SAMPLES AND METHODS}

\subsection{Sample collection}

The forty-four lignite samples were collected from four boreholes, GD-601 and GD-603 from the A field, and KB-79 and KB-
91 from the B field, Kovin deposit, as described in detail in MITROVIĆ et al. (2016, 2017; Fig. 1; Table S-I of the Supplementary Material). The samples represent different lithotypes and parts of coal seams I, II and III (Figs. 2 \& 3).

\subsection{Lithotypes and maceral analyses}

The identification of lignite lithotypes (Table 1; Figs. 2 \& 3) followed the nomenclature adopted by the ICCP (1993) and TAYLOR et al. (1998).

Polished blocks for maceral analyses were prepared according to ISO 7404-2 (2009) and performed according to ISO 7404-3 (2009). The identification of macerals followed the nomenclature developed by the International Committee for Coal and Organic Petrology for huminite (SYKOROVA et al., 2005), liptinite (PICKEL et al., 2017) and inertinite (ICCP, 2001).

\subsection{Proximate and ultimate analyses}

The proximate and ultimate analyses of lignite samples were conducted using a Vario EL III CHNS/O Elemental Analyzer, Elementar Analysensysteme $\mathrm{GmbH}$, according to several standards for the determination of analytical moisture (SRPS B.H8.390:1987, 1987), total moisture (SRPS B.H8.338:1986, 1986), ash yield (ISO $1171,1997)$ and volatile matter (SRPS B.H8.317:1988, 1988). Calorific value measurements were performed on an IKA-Calorimeter adiabatic C 400, following the standard procedure (SRPS B.H8.318:1972, 1972).

\subsection{X-ray diffraction (XRD) and SEM-EDS analysis}

Mineralogical analysis of forty-two (without the 28/91 and 31/91 samples) ash samples, heated to $450^{\circ} \mathrm{C}$ was carried out using

Table 2. Results of proximate and ultimate analyses of the Kovin lignite.

\begin{tabular}{|c|c|c|c|c|c|c|c|c|c|}
\hline \multirow{2}{*}{ Parameter } & \multicolumn{3}{|c|}{ I seam } & \multicolumn{3}{|c|}{ II Seam } & \multicolumn{3}{|c|}{ III Seam } \\
\hline & Min-Max & $\bar{x}$ & s & Min-Max & $\bar{x}$ & $s$ & Min-Max & $\bar{x}$ & s \\
\hline$W^{\text {ar }}$ (wt.\%) & $34.57-52.90$ & 44.83 & 6.33 & $14.42-52.48$ & 41.33 & 11.17 & $11.79-54.13$ & 37.91 & 16.38 \\
\hline$A^{d b}(w t . \%)$ & $12.58-52.90$ & 31.95 & 13.70 & $13.85-68.60$ & 36.26 & 18.30 & $8.66-78.20$ & 39.53 & 25.32 \\
\hline $\mathrm{S}^{\mathrm{db}}(w \mathrm{wt} . \%)$ & $0.82-4.40$ & 2.20 & 0.99 & $0.22-3.34$ & 1.60 & 0.92 & $0.21-2.13$ & 1.22 & 0.59 \\
\hline $\mathrm{Q}_{\mathrm{g}}^{\mathrm{daf}}(\mathrm{MJ} / \mathrm{kg})$ & $21.00-28.30$ & 24.29 & 1.82 & $16.90-27.80$ & 23.48 & 3.09 & $15.70-26.30$ & 23.00 & 3.71 \\
\hline $\mathrm{Q}_{\mathrm{n}}^{\mathrm{daf}}(\mathrm{MJ} / \mathrm{kg})$ & $20.10-27.20$ & 23.26 & 1.82 & $16.30-26.70$ & 22.42 & 3.02 & $14.30-25.30$ & 22.02 & 3.75 \\
\hline$C^{\text {daf }}(w t . \%)$ & $56.48-73.24$ & 64.78 & 3.92 & $52.25-74.02$ & 64.40 & 4.73 & $55.23-70.45$ & 64.96 & 5.18 \\
\hline $\mathrm{H}^{\text {daf }}(\mathrm{wt} . \%)$ & $2.95-6.53$ & 4.64 & 0.81 & $2.96-6.31$ & 4.91 & 0.75 & $2.61-6.65$ & 4.55 & 1.08 \\
\hline $\mathrm{N}^{\text {daf }}$ (wt.\%) & $0.79-1.89$ & 1.19 & 0.27 & $0.64-1.39$ & 1.05 & 0.20 & $0.79-1.51$ & 1.16 & 0.20 \\
\hline $\mathrm{O}^{\text {daf }}$ (wt.\%) & $20.09-33.73$ & 25.90 & 3.26 & $17.06-40.42$ & 27.05 & 5.00 & $21.79-41.09$ & 27.38 & 6.09 \\
\hline
\end{tabular}

$W^{\text {ar }}$ - moisture content, as received basis, \%; Wan - analytical moisture content, \%; $\mathrm{A}^{\mathrm{db}}$ - ash content, dry basis, \%; $\mathrm{S}^{\mathrm{db}}$ - total sulphur content, dry basis wt.\%; $\mathrm{V}^{\mathrm{db}}$ - volatile matter, dry basis wt.\%; $Q_{g}^{\text {daf }}$ - gross calorific value, dry, ash-free basis, $M J / k g ; Q_{n}^{\text {daf }}$ - net calorific value, dry, ash-free basis, $M J / k g ; C$ daf - carbon content, dry, ash-free basis, \%; $H^{\text {daf }}$ hidrogen content, dry, ash-free basis, \%; $\mathrm{N}^{\text {daf }}$ - nitrogen content, dry, ash-free basis; $\mathrm{O}^{\text {daf }}$ - oxigen content, dry, ash-free basis, \%; $\bar{X}$ - arithmetic mean value; Min - minimum; Max - maximum; s - standard deviation. Note: Values of parameters for individual samples are given in Table S-II of the Supplementary material to this paper. 


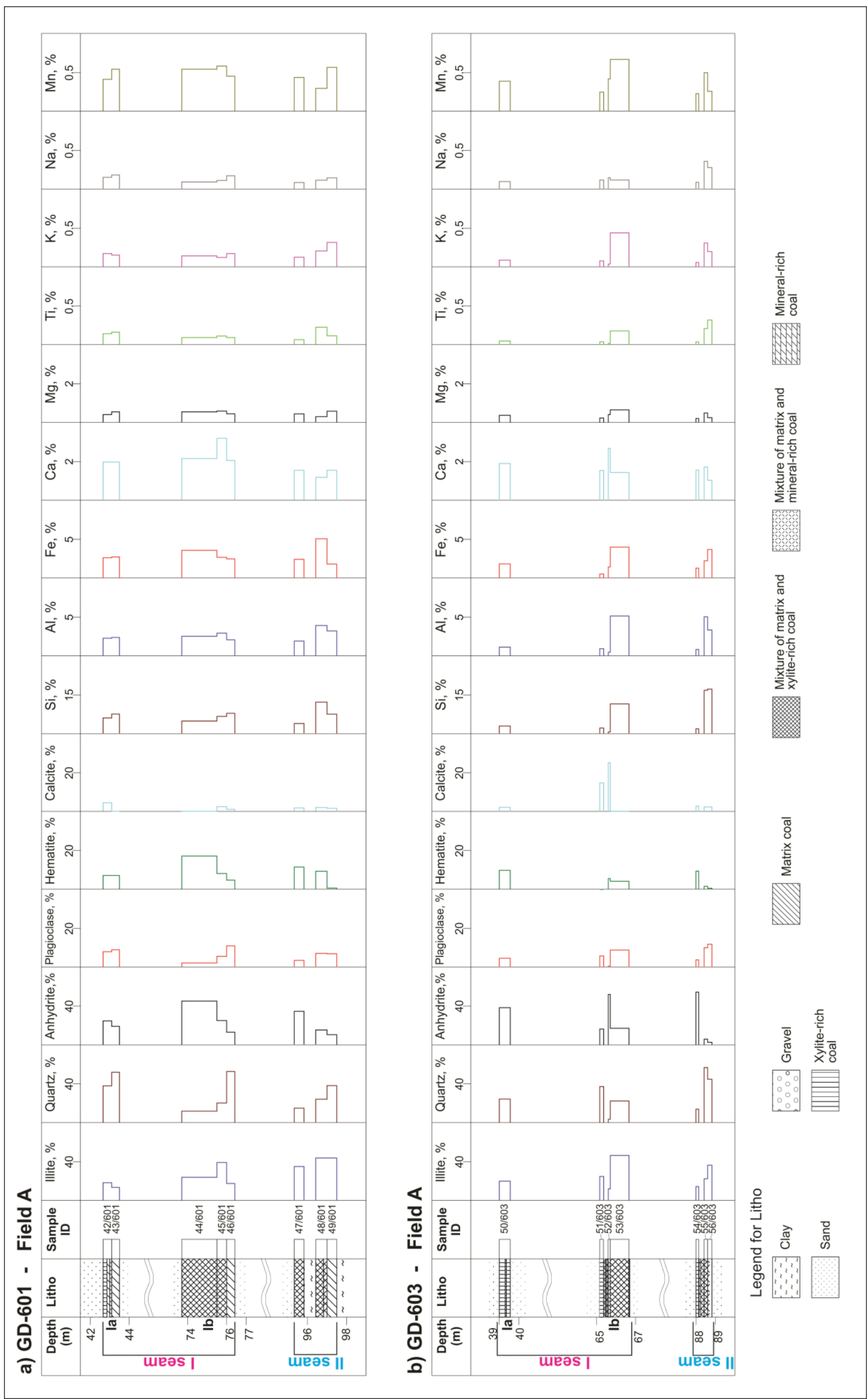

Figure 2. Macropetrographic profiles of boreholes GD-601 (a) and GD-603 (b) in the A field lignite and the vertical distribution of minerals and major elements in coal. 
X-ray powder diffraction (XRPD). Analysis was performed on a Philips PW 1710 powder diffractometer with $\mathrm{CuK} \alpha_{1,2}=1.54178$ $\AA$ radiation and a $40 \mathrm{kV}, 30 \mathrm{~mA}$. The XRD pattern was recorded over a $2 \theta$ interval of $4-70^{\circ}$, with a step size of $0.02^{\circ}$ and the fixed counting time of $1 \mathrm{~s}$ per step. X-ray diffractograms of 42 samples were subjected to quantitative mineralogical analysis using the
FullProf computer program (RODRÍGUEZ-CARVAJAL, 1993) based on the principles for diffractogram profiling set out by RIETVELD (1969). No quantification of the amorphous and sulphide phases was undertaken.

The mineral composition and distribution of some elements in the minerals were investigated in five representative samples
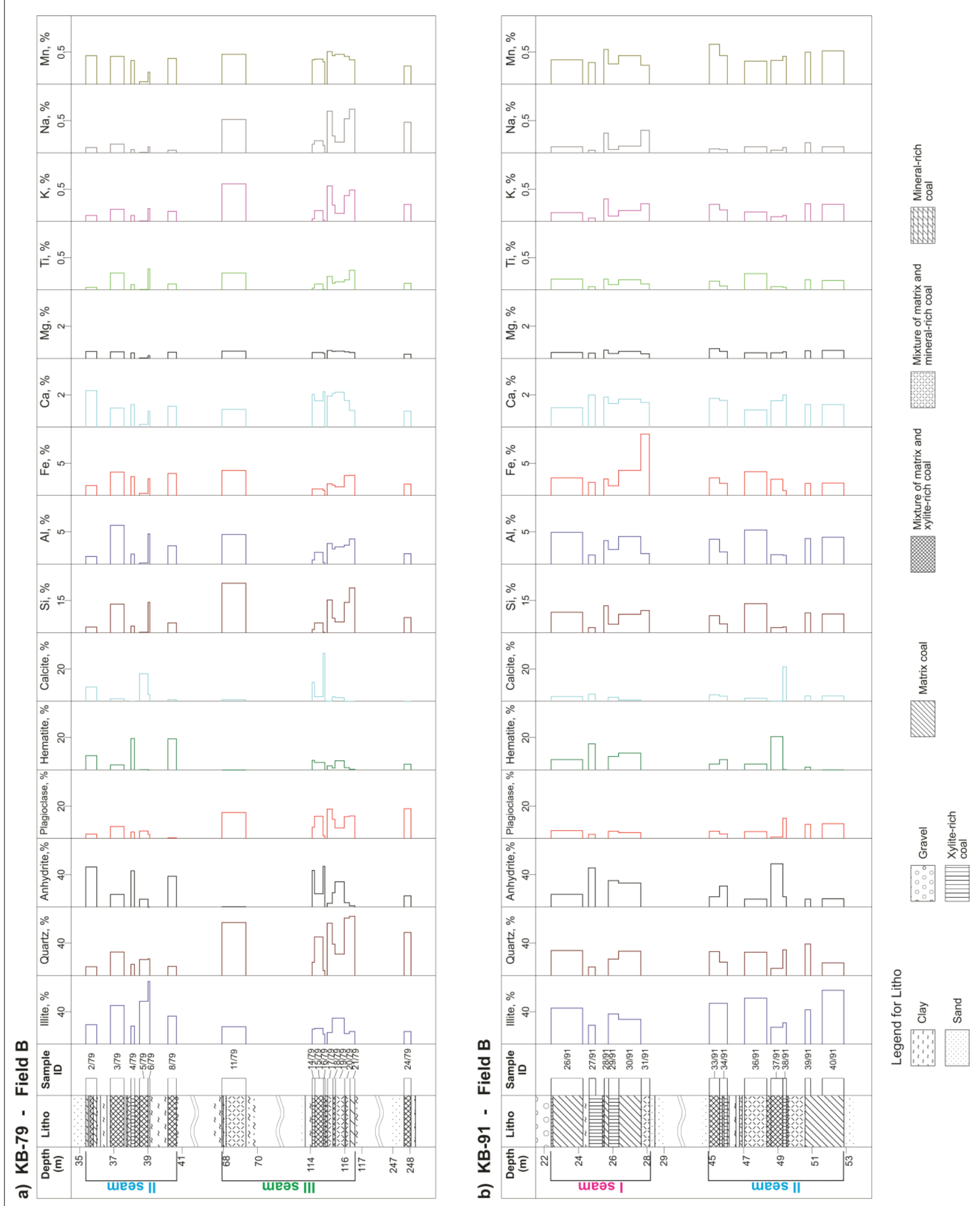

Figure 3. Macropetrographic profiles of boreholes KB-79 (a) and KB-91 (b) in the B field lignite and vertical distributions of minerals and major elements in coal. 
(53/603, 56/603, 3/79, 17/79 and 31/79) using a JEOL JSM-6610LV scanning electron microscope (30 kV accelerating voltage) equipped with an energy-dispersive X-ray spectrometer (SEMEDS; X-Max Large Area Analytical Silicon Drift connected with INCAEnergy 350 Microanalysis System). After the maceral analysis, polished blocks were coated with a thin gold film in order to obtain a higher quality secondary electron image for SEM and EDX examination.

\subsection{Inductively coupled plasma optical emission spectrometry analysis (ICP-OES)}

The contents of major and trace elements were determined by inductively coupled plasma - optical emission spectrometry (ICPOES). ICP-OES measurements were performed using a Thermo Scientific iCAP 6500 Duo ICP (Thermo Fisher Scientific, Cambridge, United Kingdom). The digestion of lignite samples was performed on an Advanced Microwave Digestion System (ETHOS 1, Milestone, Italy) using a HPR-1000/10S high pressure segmented rotor. For total dissolution, about 240-390 mg of lignite sample was precisely weighed and mixed with $6 \mathrm{ml} \mathrm{HNO}_{3}$ $(65 \%)$ and $2 \mathrm{ml} \mathrm{H}_{2} \mathrm{O}_{2}(30 \%)$, then heated by microwave energy for $30 \mathrm{~min}$. The temperature was gradually raised to $220{ }^{\circ} \mathrm{C}$ in the first $10 \mathrm{~min}$, remained at $220^{\circ} \mathrm{C}$ in the next $20 \mathrm{~min}$, and then decreased rapidly to room temperature. After cooling, the vessels were opened, $4 \mathrm{ml}$ of $\mathrm{H}_{3} \mathrm{PO}_{4}(85 \%)$ and $2 \mathrm{ml} \mathrm{HF}(40 \%)$ were added and the second phase of microwave digestion was performed under the same temperature program as the first one. All reagents were analytical grade reagents purchased from Carlo Erba, Italy. Two multi-elemental plasma standard solutions (Multi-Element Plasma Standard Solution 4, Specpure ${ }^{\circledR}, 1000$ $\mu \mathrm{g} / \mathrm{ml}$ and Semiquantitative Standard 1, Specpure $\left.{ }^{\circledR}, 10 \mu \mathrm{g} / \mathrm{ml}\right)$ and four single plasma standard solutions (Silicon, Specpure ${ }^{\circledR}$, $1000 \mu \mathrm{g} / \mathrm{ml}$; Vanadium, Specpure ${ }^{\circledR}, 1000 \mu \mathrm{g} / \mathrm{ml}$, Titanium, Specpure ${ }^{\circledR}, 1000 \mu \mathrm{g} / \mathrm{ml}$ and Molybdenum, Specpure $\left.{ }^{\circledR}, 1000 \mu \mathrm{g} / \mathrm{ml}\right)$ certified by Alfa Aesar GmbH \& Co KG, Germany, were used to prepare calibration solutions for ICP-OES measurements. The validity of the all the analytical methods results were provided using the CRM and evaluation of the test results in accordance to the reproducibility for each tested parameter, in accordance with the requirements of the SRPS ISO/IEC 17025:2006 (2006).

\section{RESULTS}

\subsection{Lithotypes and maceral composition}

The results of lithotypes and maceral analyses were taken from previous research (MITROVIĆ et al., 2016). Stratified matrix coal (Table S-I of the Supplementary material; Figs. 2, 3) predominates in the upper and the lower part of seam III, while xylite-rich coal (ICCP, 1993) predominates in the central part of the seam. Mineral-rich coal is present in thin layers near the roof of the seam. Stratified matrix coal in seam II predominates in the whole seam, while xylite-rich coal is present in thin layers near the upper and lower parts of the seam. A mixture of mineral-rich and matrix coal is present in thin layers near the floor of the seam. Stratified matrix coal in seam I predominates in the whole seam, while xylite-rich coal is present in thin layers in the upper and lower parts of the seam in field B, and in the upper part of the upper bench (Ia) in field A.

Huminite is the prevailing maceral group in all seams with telohuminite and detrohuminite as the most abundant maceral subgroups (MITROVIĆ et al., 2016; Table 1). The content of liptinite is low with liptodetrinite and sporinite as the most abundant macerals (MITROVIĆ et al., 2016). Inertinite content is low in the seam I and II, with its maximum in seam III, with inertodetrinite, fusinite and semifusinite being the most abundant macerals. Clays are the most abundant minerals, while pyrite, carbonates and other minerals are less abundant.

\subsection{Proximate and ultimate analyses}

The Kovin lignite is characterized by its high moisture content, medium to high ash yield, high volatile matter, higher sulphur content and relatively low gross and net calorific value (Table 2; Table S-II of the Supplementary material). The total moisture of most samples is variable from $34.57-52.90 \%, 14.42-52.48 \%$ and $11.79-54.13 \%$, for coal seams I, II and III, respectively (moisture being dependant on the freshness of the analysed sample material - as received basis). The ash content (dry basis) ranges from 12.58 to $52.90 \%, 13.85$ to $68.60 \%, 8.66$ to $78.20 \%$, for coal seams I, II and III respectively, which is on average from low $(<10 \%)$ to a very high ash level ( $>50 \%)$. Most of the Kovin lignite contains a low to medium sulphur (dry basis) content, whereas four samples contain a higher sulphur content of more than $3 \%$. Coal seam I has a medium (1-3\%) to high sulphur content $(>3 \%)$, with the highest content $(4.40 \%$ in sample $31 / 91$; Table S-II of the Supplementary material) in the bottom part of the seam in the B field. Total sulphur content in coal seam II ranges from medium to low, rarely high content. The highest total sulphur content at 3.12\% (sample 37/91) has been detected in the B field. Coal seam III has a medium to low sulphur content. The volatile matter on dry basis $\left(\mathrm{V}^{\mathrm{db}}\right.$; Table 2$)$ of the Kovin lignite is typically at a high level of $27.95-47.48 \%, 12.10-50.29 \%$ and $9.67-46.71 \%$, for coal seams I, II and III, respectively.

Based on the dry and ash free basis (daf), values of gross and net calorific value are typical for lignite. Coal seam I has a higher average net calorific value $(23.26 \mathrm{MJ} / \mathrm{kg})$ compared to seam II $(22.42 \mathrm{MJ} / \mathrm{kg})$, and seam III $(22.02 \mathrm{MJ} / \mathrm{kg})$. The slight variation of this parameter is detectable between lithotypes and fields. It is obvious that mineral-rich coal has the higher ash content and lower gross and net calorific value (Table S-II of the Supplementary material).

The $\mathrm{C}$ contents (daf) are similar in all three seams, averaging at $64.78 \%, 64.40 \%$ and $64.96 \%$ for coal seams I, II and III, respectively (Table I). The average $\mathrm{H}$ contents (daf) are $4.64 \%$, $4.91 \%$ and $4.55 \%$ for coal seams I, II and III, respectively, while the respective $\mathrm{O}$ contents (daf) are $25.90 \%, 27.05 \%$ and $27.38 \%$. The $\mathrm{N}$ content (daf) ranges from $0.64 \%$ to $1.89 \%$ in all samples.

\subsection{Mineralogy}

The Kovin lignite is characterized by medium (10-30\%) to very high $(>50 \%)$ mineral matter contents. XRD analyses of lignite ashes show that mineral matter in the coal seam I (Table 3; Figs. 2, 3; Table S-II of the Supplementary material; Figs. S1, S2 of the Supplementary material) consists mainly of anhydrite (13.10$52.28 \%$ ), quartz (3.97-52.61\%) and illite/smectite (12.05-46.66\%) with variable proportions of haematite (4.37-17.13\%), plagioclase $(0.67-10.96 \%)$ and calcite $(0.01-25.30 \%)$. It should be noted that smectite cannot be identified on XRD powder diffractograms after heating/burning at $450^{\circ} \mathrm{C}$, so in further text illite/smectite will always include both phases. Also, the content of anhydrite and haematite should be carefully taken into account, because they could be formed during the ashing process (WARD, 2002, 2016). Quartz is more abundant in the A field, while illite/smectite dominates in the B field. The mineral matter in coal seam II ash consists of illite/smectite (14.79-73.55\%), quartz (8.62-57.19\%) and 
Table 3. XRD analysis of the Kovine lignite ash.

\begin{tabular}{|c|c|c|c|c|c|c|c|c|c|}
\hline \multirow[t]{2}{*}{ Parameter } & \multicolumn{3}{|c|}{ I seam } & \multicolumn{3}{|c|}{ II Seam } & \multicolumn{3}{|c|}{ III Seam } \\
\hline & Min-Max & $\bar{x}$ & s & Min-Max & $\bar{x}$ & s & Min-Max & $\bar{x}$ & s \\
\hline Illite/smectite & $12.05-46.66$ & 26.51 & 11.11 & $14.79-73.55$ & 38.92 & 15.64 & $11.68-30.77$ & 19.01 & 7.17 \\
\hline Quartz & $3.97-52.61$ & 26.91 & 14.92 & $8.62-57.19$ & 24.05 & 13.05 & $6.03-69.30$ & 43.36 & 23.57 \\
\hline Anhydrite & $13.10-52.28$ & 28.53 & 13.07 & $3.16-54.64$ & 22.33 & 17.06 & $0.59-47.67$ & 18.38 & 17.83 \\
\hline Plagioclase & $0.67-10.96$ & 5.39 & 3.02 & $0.49-11.99$ & 5.51 & 3.44 & $1.68-17.21$ & 10.85 & 4.99 \\
\hline Hematite & $4.37-17.13$ & 8.57 & 3.97 & $0.25-19.59$ & 6.82 & 6.70 & $0.13-5.73$ & 2.91 & 2.15 \\
\hline Calcite & $0.01-25.30$ & 5.14 & 7.47 & $0.39-20.33$ & 4.50 & 5.36 & $0.07-28.38$ & 6.18 & 9.66 \\
\hline
\end{tabular}

$\bar{X}$ - arithmetic mean value; Min - minimum; Max - maximum; $s$ - standard deviation.

Note: Values of parameters for individual samples are given in Table S-III of the Supplementary material to this paper.

anhydrite (3.16-54.64\%) with variable amounts of haematite $(0.25-19.59 \%)$, plagioclase $(0.49-11.99 \%)$ and calcite $(0.39-$ $20.33 \%$ ). Illite/smectite and quartz are almost equally abundant in the A field, while illite again prevails in the B field. The most abundant mineral matter in coal seam III ash is quartz (6.03$69.30 \%)$, while illite/smectite (11.68-30.77\%), anhydrite $(0.59$ $47.67 \%)$, plagioclase $(1.68-17.21 \%)$, calcite $(0.07-28.38 \%)$ and haematite $(0.13-5.73 \%)$ are less abundant.

SEM-EDS examination revealed that the most abundant minerals in all the studied lignite samples are clays (illite/smectite; Table 4; Fig. 4), silicates (quartz, plagioclase), sulphate (gypsum/anhydrite) and carbonate (calcite). The other iron-rich minerals are sulphides, oxides and hydroxides (pyrite, magnetite, haematite, and limonite) and plagioclase. Minor minerals such as rutile, ilmenite, K-feldspar (albite, orthoclase), and mica, were detected in all coal seams. In addition, in seam I, barite, chlorite, epidote, allanite and zircon were also detected. Samples from

Table 4. Mineral composition of the Kovin lignite, based on data from SEM-EDS.

\begin{tabular}{|c|c|c|c|}
\hline \multirow{2}{*}{ Mineral phases } & \multicolumn{3}{|c|}{ Content } \\
\hline & I seam & II seam & III seam \\
\hline \multicolumn{4}{|l|}{ Sulphides } \\
\hline Pyrite & $\mathrm{m}$ & $\mathrm{m}$ & $\mathrm{m}$ \\
\hline Sphalerite & & $\mathrm{m}$ & \\
\hline Galena & & $\mathrm{m}$ & \\
\hline \multicolumn{4}{|l|}{ Sulphate } \\
\hline Gypsum/Anhydrite & M & M & M \\
\hline Barite & $\mathrm{m}$ & & $\mathrm{m}$ \\
\hline \multicolumn{4}{|l|}{ Oxides and hydroxides } \\
\hline Limonite & $\mathrm{m}$ & & \\
\hline Hematite & M & M & M \\
\hline Rutile & $\mathrm{m}$ & $\mathrm{m}$ & $\mathrm{m}$ \\
\hline Ilmenite & $\mathrm{m}$ & $\mathrm{m}$ & $\mathrm{m}$ \\
\hline Mn-Fe oxides & $\mathrm{m}$ & $\mathrm{m}$ & \\
\hline Mn hydroxides & $\mathrm{m}$ & $\mathrm{m}$ & \\
\hline \multicolumn{4}{|l|}{ Silicates } \\
\hline Quartz & M & M & M \\
\hline Opal/chalcedony & & & $\mathrm{m}$ \\
\hline Illite & M & M & M \\
\hline Smectite & & $\mathrm{m}$ & \\
\hline Mica (biotite, muscovite) & $\mathrm{m}$ & $\mathrm{m}$ & $\mathrm{m}$ \\
\hline Chlorite & $\mathrm{m}$ & $\mathrm{m}$ & \\
\hline Plagioclase (albite) & M & M & M \\
\hline K-feldspar (orthoclase) & $\mathrm{m}$ & $\mathrm{m}$ & $\mathrm{m}$ \\
\hline Epidote & $\mathrm{m}$ & $\mathrm{m}$ & \\
\hline Allanite (orhite) & $\mathrm{m}$ & & \\
\hline Zircon & $\mathrm{m}$ & & \\
\hline \multicolumn{4}{|l|}{ Carbonates } \\
\hline Calcite & M & M & $M$ \\
\hline Siderite & & $\mathrm{m}$ & \\
\hline Dolomite & & $\mathrm{m}$ & \\
\hline Ankerite & & $\mathrm{m}$ & \\
\hline \multicolumn{4}{|l|}{ Phosphate } \\
\hline Monazite & & $\mathrm{m}$ & $\mathrm{m}$ \\
\hline
\end{tabular}

M-major mineral (>1 vol.\%); m-minor mineral (<1 vol.\%) seam II contain sphalerite, galena, siderite, dolomite, ankerite and monazite, while in coal seam III barite and monazite were found.

The silicate and aluminosilicate minerals are common constituents of the inorganic matter in Kovin lignites and include mainly quartz, illite/smectite, rarely chlorite and plagioclase, and more rarely, mica (biotite, muscovite), and K-feldspar (Fig. 4). Quartz is a major inorganic component of the Kovin lignites, especially in coal seam III (Table 4). Some parts of seams I and II have very high quartz contents. It is recognized as single angular to semi-rounded grains of predominantly detrital origin (WARD, 2002), but authigenic crystals were also determined. Epigenetic quartz, along with clay minerals, pyrite, and carbonates, was formed within cleats and fractures in the organic matrix, as a result of the circulation of meteoric waters.

The clay minerals, represented by illite/smectite and chlorite, are typical constituents of the inorganic matter, especially in coal seam II. They are mostly of detrital origin (WARD, 2016), but a small part may be diagenetic, formed as weathering products of feldspar and mica, and usually occurring as layers, lenses and films on the surface of macerals. Illite and smectite are present as finely dispersed aggregates of irregular size and rarely as long platy crystals. Clay minerals of epigenetic origin, which precipitated in fractures, were also observed.

Feldspars are represented by plagioclase (albite; Fig. 4a) and subordinate K-feldspar (orthoclase; Fig. 4b). They are detrital in origin and are usually associated with clays. Mica (biotite and muscovite; Fig. 4c) is represented by platy or irregular shaped crystals, usually in association with feldspars in clay-rich layers. The mica is predominantly of detrital origin, but a small part might be a weathering product of feldspars. During the processes of coal formation mica is unstable and could transform to chlorite, limonite, and clay minerals. Chlorite (Cr-rich chlorite as well, Fig. 4d) was found in the I and II seams. The majority of the chlorite in the Kovin lignite is of detrital origin, formed as a weathering product of the crystalline basement rocks.

Detrital epidote, a calcium, aluminium and iron sorosilicate mineral (Fig. 4e), occurs as individual crystals of irregular shapes.

Sulphates, anhydrite $\left(\mathrm{CaSO}_{4}\right.$; Fig. $\left.4 \mathrm{f}\right)$ possibly gypsum as well, were determined in high amounts in several samples. In raw lignite, sulphate minerals are authigenic (mainly epigenetic) and/ or occur as weathering products. Barite $\left(\mathrm{BaSO}_{4}\right.$; Fig. $\left.4 \mathrm{~g}\right)$ was determined in very low amounts.

The Fe oxides and hydroxides (haematite and limonite) are present in considerable amounts in the Kovin lignites. A large proportion of the Fe-oxide/hydroxides in the Kovin lignite samples (Fig. 4h) is probably the result of the weathering of iron-rich minerals such as pyrite and siderite. A small proportion of these minerals might also be of detrital origin. Limonite (a mixture of goethite, lepidocrocite, and other Fe-hydroxides) in the Kovin 

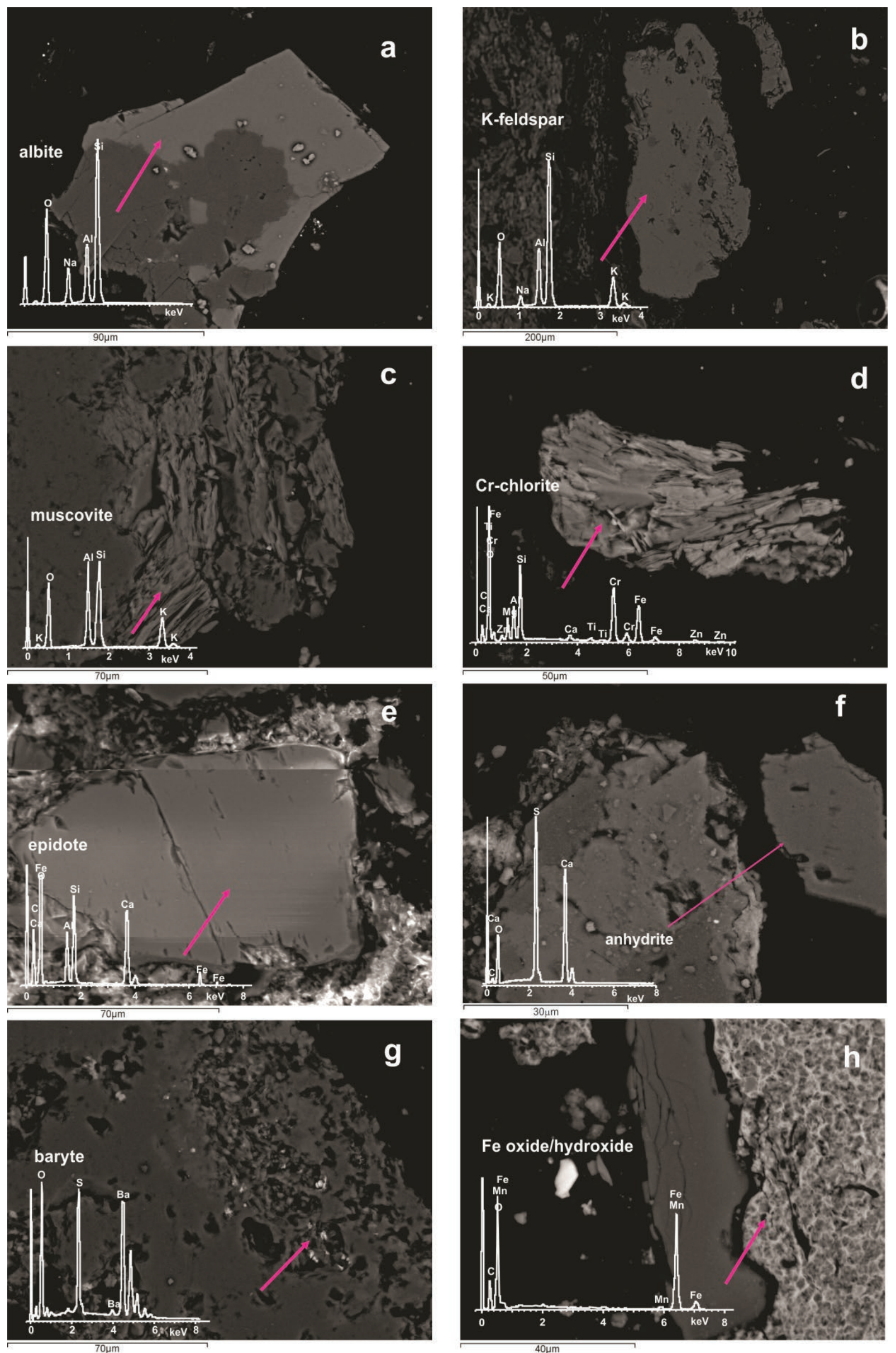

Figure 4. SEM backscatter images with EDS data of minerals; a) albite; b) K-feldspar; c) muscovite; d) Cr-rich chlorite; e) epidote; f) gypsum/anhydrite; g) barite; h) Fe oxide/hydroxide. 

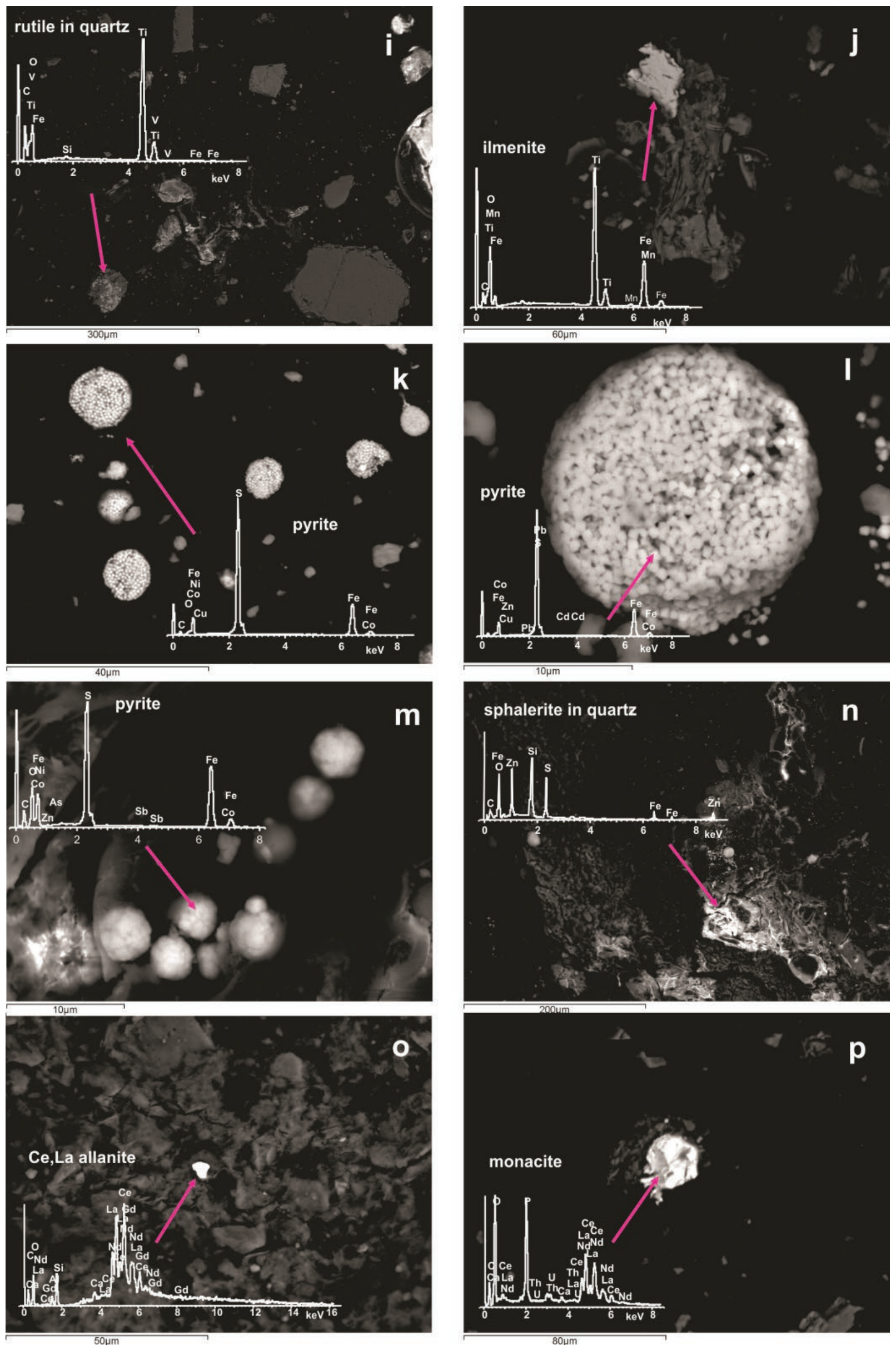

Figure 4. continued; i) rutile in quartz; j) ilmenite; $\mathrm{k}-\mathrm{m}$ ) pyrite; $\mathrm{n}$ ) sphalerite in quartz; o) $\mathrm{Ce}$, La allanite, p) monazite. 
Table 5. Contents of the major elements in the Kovin lignite.

\begin{tabular}{|c|c|c|c|c|c|c|c|c|c|c|c|c|c|}
\hline \multirow{2}{*}{ Element } & \multicolumn{4}{|l|}{ I seam } & \multicolumn{3}{|l|}{ II seam } & \multicolumn{3}{|c|}{ III seam } & \multirow[b]{2}{*}{$\mathrm{s}$} & \multirow[b]{2}{*}{$\bar{X}_{g}$} & \multirow{2}{*}{$\begin{array}{c}\text { Clarke value of } \\
\text { - brown coals } \\
\text { ppm }\end{array}$} \\
\hline & Min-Max & $\bar{x}$ & s & $\bar{X}_{g}$ & Min-Max & $\bar{x}$ & $\mathrm{~s}$ & $\bar{X}_{g}$ & Min-Max & $\bar{x}$ & & & \\
\hline \multicolumn{14}{|c|}{ Major elements, \% } \\
\hline $\mathrm{Si}$ & $0.88-11.87$ & 6.40 & 3.45 & 5.26 & $0.40-17.33$ & 7.50 & 5.31 & 5.40 & $0.34-21.84$ & 9.68 & 7.92 & 4.88 & \\
\hline $\mathrm{Al}$ & $0.52-5.15$ & 2.48 & 1.36 & 2.11 & $0.20-5.72$ & 2.90 & 1.61 & 2.31 & $0.26-4.37$ & 2.39 & 1.33 & 1.38 & - \\
\hline $\mathrm{Si} / \mathrm{Al}$ & $1.67-6.17$ & 2.66 & 1.16 & 2.19 & $2.06-5.12$ & 3.03 & 1.14 & 2.88 & $1.28-5.34$ & 3.39 & 1.54 & 2.45 & \\
\hline $\mathrm{Fe}$ & $0.59-9.01$ & 2.88 & 1.92 & 2.45 & $0.36-5.03$ & 2.38 & 1.11 & 2.08 & $0.80-3.70$ & 1.91 & 1.05 & 1.56 & - \\
\hline $\mathrm{Ti}$ & $0.02-0.18$ & 0.10 & 0.05 & 0.09 & $0.01-0.32$ & 0.13 & 0.10 & 0.10 & $0.01-0.29$ & 0.14 & 0.09 & 0.08 & $720 \pm 40$ \\
\hline $\mathrm{Ca}$ & $1.14-3.19$ & 1.88 & 0.52 & 1.81 & $0.17-2.15$ & 1.36 & 0.42 & 1.25 & $0.98-2.10$ & 1.67 & 0.42 & 1.09 & - \\
\hline $\mathrm{Mg}$ & $0.25-0.67$ & 0.43 & 0.12 & 0.41 & $0.04-0.59$ & 0.38 & 0.13 & 0.34 & $0.33-0.48$ & 0.40 & 0.05 & 0.24 & - \\
\hline $\mathrm{Na}$ & $0.04-0.33$ & 0.14 & 0.08 & 0.12 & $0.01-0.36$ & 0.11 & 0.08 & 0.08 & $0.11-0.64$ & 0.34 & 0.22 & 0.27 & - \\
\hline $\mathrm{Mn}$ & $0.01-0.15$ & 0.03 & 0.04 & 0.02 & $0.001-0.04$ & 0.02 & 0.01 & 0.01 & $0.01-0.03$ & 0.02 & 0.01 & 0.01 & $100 \pm 6$ \\
\hline
\end{tabular}

lignite occurs mainly as collomorphous crusts built up of small flakes and usually appears in association with haematite and other minerals including siderite and clays. The Fe-Mn oxides and Mn hydroxides were also detected in small amounts in coal seams I and II. The Ti and Ti-Fe oxides (rutile and ilmenite; Fig. 4i, j) occur as small aggregates in low amounts in all seams.

One of the most abundant carbonate minerals in the Kovin lignite is calcite, whereas the other carbonates such as siderite, dolomite and ankerite are present in small amounts. Calcite was determined in significant amounts in the central part of seams II and III (Table 4), as well as in the lower bench of seam I in field A. Carbonates occur as individual rounded and angular grains and spherical aggregates which implies most probably their syn- genetic origin. Siderite was observed in small amounts in seam II and occurs as fine-grained lenses, layers and crusts, which are intimately associated with organic matter, suggesting most probably a syngenetic origin. Dolomite occurs as small angular grains in low amounts in the central part of seam II in field B.

Pyrite is one of the most abundant sulphide minerals and a typical authigenic mineral in the Kovin lignite (Fig. 4k, 1, m). Syngenetic pyrite occurs as framboidal and euhedral crystals (CHOU, 2012), situated along stratified bands or infilling cavities within the organic matter and cell openings of plant debris. Crystals were formed within the lumens of densinite and textinite. Very small amounts of epigenetic pyrite were determined. Sphalerite and galena were detected in small amounts in seam II (Fig. 4n).

Table 6. Trace element content of the Kovin lignite.

\begin{tabular}{|c|c|c|c|c|c|c|c|c|c|c|c|c|c|}
\hline \multirow{2}{*}{ Element } & \multicolumn{4}{|l|}{ I seam } & \multicolumn{3}{|l|}{ II seam } & \multicolumn{3}{|c|}{ III seam } & \multirow[b]{2}{*}{ s } & \multirow[b]{2}{*}{$\bar{X}_{g}$} & \multirow{2}{*}{$\begin{array}{c}\text { Clarke value of } \\
\text { brown coala } \\
\text { ppm }\end{array}$} \\
\hline & Min-Max & $\bar{x}$ & s & $\bar{X}_{g}$ & Min-Max & $\bar{x}$ & S & $\bar{X}_{g}$ & Min-Max & $\bar{x}$ & & & \\
\hline As & $4.00-140.00$ & 30.86 & 33.04 & 21.53 & $4.30-70.40$ & 26.68 & 17.89 & 20.17 & $4.50-21.20$ & 12.76 & 5.53 & 11.59 & $7.6 \pm 1.3$ \\
\hline $\mathrm{Ba}$ & $40.88-173.15$ & 90.41 & 38.23 & 83.44 & $9.27-170.27$ & 90.24 & 41.54 & 77.50 & $61.2-239.83$ & 148.11 & 72.86 & 131.03 & $150 \pm 20$ \\
\hline $\mathrm{Cd}$ & $0.58-6.45$ & 2.04 & 1.39 & 1.74 & $0.20-3.19$ & 1.69 & 0.72 & 1.48 & $0.72-2.32$ & 1.40 & 0.55 & 1.30 & $0.24 \pm 0.04$ \\
\hline Co & $3.40-35.80$ & 12.95 & 8.46 & 10.94 & $2.50-34.30$ & 13.90 & 9.63 & 11.04 & $1.50-25.10$ & 13.19 & 8.25 & 9.72 & $4.2 \pm 0.3$ \\
\hline $\mathrm{Cr}$ & $35.24-371.41$ & 111.65 & 87.50 & 88.93 & $8.38-226.73$ & 96.89 & 57.31 & 78.59 & $11.86-265.33$ & 123.58 & 97.57 & 84.04 & $15 \pm 1$ \\
\hline $\mathrm{Cu}$ & $3.53-72.54$ & 31.95 & 21.03 & 23.38 & $3.14-77.21$ & 39.03 & 23.49 & 30.13 & $3.79-62.41$ & 35.64 & 22.01 & 25.95 & $15 \pm 1$ \\
\hline $\mathrm{Ga}$ & $2.10-16.30$ & 8.85 & 4.38 & 7.58 & $0.90-25.60$ & 11.26 & 7.39 & 8.56 & $1.00-16.50$ & 8.12 & 5.02 & 6.34 & $5.5 \pm 0.3$ \\
\hline $\mathrm{Li}$ & $3.82-54.11$ & 23.09 & 14.68 & 18.47 & $2.21-85.06$ & 37.95 & 27.01 & 27.50 & $1.75-37.88$ & 20.38 & 11.33 & 15.17 & $10 \pm 1$ \\
\hline Mo & $1.10-11.50$ & 6.00 & 2.82 & 5.25 & $0.70-9.80$ & 5.16 & 2.26 & 4.49 & $1.90-8.90$ & 4.72 & 2.08 & 4.32 & $2.2 \pm 0.2$ \\
\hline $\mathrm{Pb}$ & $6.88-175.67$ & 68.55 & 45.63 & 51.85 & $4.06-179.87$ & 63.82 & 45.08 & 47.18 & $2.84-82.10$ & 43.49 & 24.31 & 31.77 & $6.6 \pm 0.4$ \\
\hline $\mathrm{Rb}$ & $0.39-36.06$ & 9.67 & 9.16 & 6.40 & $0.79-32.97$ & 9.99 & 8.01 & 7.05 & $0.84-36.25$ & 15.76 & 10.80 & 11.10 & $10 \pm 0.9$ \\
\hline $\mathrm{Sb}$ & & $<0.5$ & & & & $<0.5$ & & & & $<0.5$ & & & $0.84 \pm 0.09$ \\
\hline Sc & $1.24-11.24$ & 6.01 & 3.08 & 5.13 & $0.64-15.06$ & 7.18 & 4.34 & 5.70 & $0.62-8.14$ & 4.98 & 2.19 & 4.20 & $4.1 \pm 0.2$ \\
\hline $\mathrm{Se}$ & $1.30-9.00$ & 3.02 & 1.96 & 2.62 & $0.30-4.90$ & 2.25 & 0.99 & 2.00 & $0.90-4.30$ & 2.41 & 1.17 & 2.15 & $1.0 \pm 0.15$ \\
\hline $\mathrm{Sr}$ & $46.04-253.06$ & 100.78 & 54.12 & 90.59 & $10.19-176.12$ & 88.80 & 33.85 & 79.91 & $120.71-218.89$ & 184.17 & 30.71 & 181.58 & $120 \pm 10$ \\
\hline Th & $0.10-3.70$ & 1.37 & 1.03 & 0.92 & $0.10-2.60$ & 1.32 & 0.76 & 0.97 & $1.40-2.90$ & 2.17 & 0.56 & 2.11 & $3.3 \pm 0.2$ \\
\hline $\mathrm{TI}$ & & $<0.5$ & & & & $<0.5$ & & & & $<0.5$ & & & $0.68 \pm 0.07$ \\
\hline V & $7.60-76.82$ & 41.56 & 19.32 & 35.89 & $6.46-110.76$ & 53.03 & 29.93 & 43.18 & $3.31-54.51$ & 33.18 & 15.88 & 26.89 & $22 \pm 2$ \\
\hline $\mathrm{Zn}$ & $11.18-174.79$ & 49.72 & 43.24 & 37.18 & $3.95-239.66$ & 69.75 & 60.79 & 48.58 & $4.30-62.52$ & 31.22 & 18.72 & 24.21 & $18 \pm 1$ \\
\hline
\end{tabular}


Table 7. Rare earth element content in the Kovin lignite.

\begin{tabular}{|c|c|c|c|c|c|c|c|c|c|c|c|c|c|}
\hline \multirow{2}{*}{ Element } & \multicolumn{4}{|l|}{ I seam } & \multicolumn{4}{|l|}{ II seam } & \multicolumn{4}{|l|}{ III seam } & \multirow{2}{*}{$\begin{array}{c}\text { Clarke value of } \\
\text { Brown coala } \\
\text { ppm }\end{array}$} \\
\hline & Min-Max & $\bar{x}$ & s & $\bar{X}_{g}$ & Min-Max & $\bar{x}$ & s & $\bar{X}_{g}$ & Min-Max & $\bar{x}$ & s & $\bar{X}_{g}$ & \\
\hline La & $3.56-12.86$ & 7.25 & 3.00 & 6.66 & $0.81-10.77$ & 5.70 & 2.7 & 4.95 & $1.90-15.21$ & 8.05 & 4.02 & 6.92 & $10 \pm 0.5$ \\
\hline $\mathrm{Ce}$ & $5.00-28.70$ & 13.24 & 6.34 & 11.89 & $1.70-17.80$ & 10.79 & 4.41 & 9.59 & $2.70-21.40$ & 13.92 & 6.35 & 11.93 & $22 \pm 1$ \\
\hline $\operatorname{Pr}$ & $1.80-5.90$ & 3.42 & 1.31 & 3.19 & $0.40-5.40$ & 2.97 & 1.32 & 2.59 & $1.40-7.10$ & 4.36 & 1.74 & 3.96 & $3.5 \pm 0.3$ \\
\hline $\mathrm{Nd}$ & $2.90-10.20$ & 6.15 & 2.35 & 5.71 & $0.80-9.90$ & 5.23 & 2.43 & 4.53 & $1.70-10.80$ & 6.81 & 2.82 & 6.06 & $11 \pm 1$ \\
\hline $\mathrm{Sm}$ & $0.15-2.20$ & 1.08 & 0.61 & 0.86 & $0.10-1.70$ & 1.02 & 0.44 & 0.88 & $0.10-1.60$ & 0.89 & 0.48 & 0.71 & $1.9 \pm 0.1$ \\
\hline $\mathrm{Eu}$ & $0.23-1.59$ & 0.63 & 0.35 & 0.55 & $0.08-0.83$ & 0.52 & 0.19 & 0.47 & $0.15-0.84$ & 0.55 & 0.22 & 0.49 & $0.5 \pm 0.02$ \\
\hline $\mathrm{Gd}$ & $3.53-11.18$ & 7.39 & 2.57 & 6.93 & $0.76-15.70$ & 8.05 & 4.07 & 6.78 & $2.48-14.57$ & 8.61 & 4.10 & 7.53 & $2.6 \pm 0.2$ \\
\hline $\mathrm{Tb}$ & $0.20-2.10$ & 0.97 & 0.53 & 0.82 & $0.10-4.50$ & 1.72 & 1.11 & 1.29 & $0.50-3.10$ & 1.39 & 1.09 & 1.07 & $0.32 \pm 0.03$ \\
\hline Dy & $0.33-2.68$ & 1.27 & 0.75 & 1.06 & $0.13-1.94$ & 1.02 & 0.48 & 0.87 & $0.11-1.63$ & 1.15 & 0.47 & 0.95 & $2.0 \pm 0.1$ \\
\hline$Y$ & $2.09-17.54$ & 7.96 & 4.74 & 6.69 & $0.76-13.47$ & 6.43 & 2.95 & 5.58 & $0.99-8.67$ & 6.40 & 2.43 & 5.59 & $8.6 \pm 0.4$ \\
\hline $\mathrm{Ho}$ & $0.04-1.35$ & 0.51 & 0.34 & 0.39 & $0.06-0.80$ & 0.49 & 0.21 & 0.41 & $0.05-0.93$ & 0.54 & 0.30 & 0.42 & $0.50 \pm 0.05$ \\
\hline $\mathrm{Er}$ & $0.40-2.45$ & 1.22 & 0.67 & 1.05 & $0.14-1.92$ & 1.03 & 0.38 & 0.93 & $0.21-1.23$ & 0.98 & 0.34 & 0.88 & $0.85 \pm 0.08$ \\
\hline $\mathrm{Tm}$ & $0.12-0.52$ & 0.27 & 0.13 & 0.24 & $0.03-0.36$ & 0.22 & 0.09 & 0.19 & $0.08-0.38$ & 0.27 & 0.09 & 0.25 & $0.31 \pm 0.02$ \\
\hline $\mathrm{Yb}$ & $0.31-2.71$ & 1.26 & 0.72 & 1.07 & $0.14-2.00$ & 1.13 & 0.45 & 1.00 & $0.15-1.38$ & 0.99 & 0.40 & 0.86 & $1.0 \pm 0.05$ \\
\hline $\mathrm{Lu}$ & $0.14-2.65$ & 0.75 & 0.59 & 0.61 & $0.09-1.19$ & 0.61 & 0.30 & 0.52 & $0.13-0.91$ & 0.52 & 0.29 & 0.43 & $0.19 \pm 0.02$ \\
\hline LREYb & $14.01-51.15$ & 31.15 & 12.55 & 28.64 & $3.81-43.60$ & 25.71 & 10.70 & 22.79 & $7.80-55.31$ & 34.02 & 14.86 & 29.79 & \\
\hline$M R E Y^{b}$ & $6.46-33.22$ & 18.09 & 7.97 & 16.37 & $1.73-24.13$ & 17.27 & 6.14 & 15.36 & $4.23-26.43$ & 17.94 & 7.45 & 15.93 & \\
\hline HREYb & $1.16-9.45$ & 4.01 & 2.31 & 3.42 & $0.46-5.95$ & 3.46 & 1.31 & 3.10 & $0.61-4.66$ & 3.30 & 1.33 & 2.89 & \\
\hline$\Sigma \mathrm{REY}$ & $22.17-87.75$ & 53.25 & 21.91 & 48.72 & $6.0-69.96$ & 46.45 & 16.07 & 42.03 & $12.64-82.63$ & 55.26 & 22.76 & 48.87 & \\
\hline
\end{tabular}

a KETRIS \& YUDOVICH, 2009; b SEREDIN \& DAI, 2012; LREY = La+Ce + Pr + Nd + Sm; MREY = Eu + Gd + Tb + Dy + Y; HREY = Ho + Er + Tm + Yb + Lu; Min - minimum; Max - maximum; $\bar{X}$ - arithmetic mean value; $s$ - standard deviation; $\bar{X}_{g}$ - geometric mean value.

Note: Values of parameters for individual samples are given in Table S-III for major elements, S-IV for trace elements and S-V for Rare earth elements and yttrium of the Supplementary material to this paper.

Rare grains of REY-rich phosphates, monazite (Fig. 4o) of irregular shape were detected in coal seams II and III. Ce, La allanite (calcium, aluminium, iron sorosilicate mineral; Fig. 4p), probably of detrital origin, occur as individual small crystals of irregular shapes in coal seam I.

\subsection{Geochemistry}

Variations of the $\mathrm{Si}, \mathrm{Al}$, Ti and $\mathrm{K}$ contents in the studied samples are obvious in each seam and mostly depend on coal lithotypes (Table 5; Table S-IV of the Supplementary material to this paper; Figs. 2, 3). It is obvious that the mineral-rich and mixture of matrix and mineral-rich coal have high contents of the aforementioned major elements. The average Si contents in the Kovin lignites are $6.40 \%, 7.50 \%$ and $9.68 \%$ for coal seams I, II and III, respectively, while the respective $\mathrm{Al}$ contents are $2.48 \%, 2.90 \%$ and $2.39 \%$. A high $\mathrm{Si} / \mathrm{Al}$ ratio in all three seams (Table 5) implies high contents of quartz, illite/smectite and plagioclase.

The lignite from the Kovin deposit is enriched in As, Cd, Co, $\mathrm{Cr}, \mathrm{Cu}, \mathrm{Ga}, \mathrm{Li}, \mathrm{Mn}, \mathrm{Mo}, \mathrm{Ni}, \mathrm{Pb}, \mathrm{V}, \mathrm{Zn}, \mathrm{Gd}, \mathrm{Tb}$, Er and Lu in comparison with Clarke values for brown coals (KETRIS \& YUDO$\mathrm{VICH}, 2009)$. The lignite in seam I is particularly enriched in As (4.00-140.00 mg/kg), Cr (35.24-371.41 mg/kg), Ni (13.70-214.00 $\mathrm{mg} / \mathrm{kg}), \mathrm{Pb}(6.88-175.76 \mathrm{mg} / \mathrm{kg})$ and $\mathrm{Zn}(11.18-174.79 \mathrm{mg} / \mathrm{kg})$, (Table 6; Table S-V of the Supplementary material to this paper; Figs. 5, 6). The bottom part of seam I in field B (sample 31/91) with high ash (52.56\%, dry basis; Fig. 6) and the highest total sulphur content (4.40\%, dry basis), Si/Al ratio (6.17), Fe (9.01\%, dry basis) and $\mathrm{Mn}(0.15 \%$, dry basis) content has the highest content of all mentioned elements except $\mathrm{Pb}$ and $\mathrm{Zn}$ (Table $\mathrm{S}-\mathrm{V}$ of the Supplementary material to this paper). The coal in seam II is es- pecially enriched in As (4.30-70.40 mg/kg), Cr (8.38-226.73 mg/ $\mathrm{kg})$, Li (2.21-85.06 mg/kg), Ni (9.40-206.10 mg/kg), Pb (4.06$179.87 \mathrm{mg} / \mathrm{kg}), \mathrm{V}(6.36-110.76 \mathrm{mg} / \mathrm{kg})$ and $\mathrm{Zn}(3.95-239.66 \mathrm{mg} /$ $\mathrm{kg})$. Coal from seam III is enriched in $\mathrm{Ba}(61.23-239.83 \mathrm{mg} / \mathrm{kg})$, $\mathrm{Cr}(11.86-265.33 \mathrm{mg} / \mathrm{kg}$ ) and $\mathrm{Sr}(120.71-218.89 \mathrm{mg} / \mathrm{kg})$.

There are several geochemical and economic classifications of rare earth elements and yttrium (REY; SEREDIN, 2010; SEREDIN \& DAI, 2012). The three-fold geochemical classification, which divides REY into light (LREY - La, Ce, Pr, Nd, and Sm), medium (MREY - Eu, Gd, Tb, Dy, and Y), and heavy (HREY - Ho, Er, Tm, Yb, and Lu) groups according to SEREDIN \& DAI (2012) is more convenient for the description of REY distribution in coals and conventional REY ores. The content of LREY, MREY and HREY in the Kovin lignite is generally low in all seams (Table 7; Table S-VI of the Supplementary material to this paper) with a predominance of LREY in all three seams. The average LREY contents in lignite are $31.15 \mathrm{mg} / \mathrm{kg}, 25.71 \mathrm{mg} / \mathrm{kg}$ and $34.02 \mathrm{mg} / \mathrm{kg}$ for seams I, II and III respectively. The Gd, Tb, Er and Lu contents are higher than the Clarke values for brown coals (KETRIS \& YUDOVICH, 2009), based on calculation of average individual lanthanides and $\mathrm{Y}$.

\section{DISCUSSION}

The mineral matter in coal seams and deposits depends on the combination of specific plant constituents influenced by water level, regional depositional and paleo-environmental factors, which control the enrichment or depletion of the different elements and mineral phases contained in the coal. Chemical, biological and physical factors in mire systems provide specific environments in which minerals could be deposited or formed 
(GLUSKOTER, 1975; TAYLOR et al., 1998; WARD, 2016). Epigenetic factors may also influence the variation in elements (CHRISTANIS et al., 1998; KALAITZIDIS et al., 2002; DAI et al., 2012). The modes of mineral occurrences, their abundance and distribution in coal may characterize seams, deposits, and facies changes. It can be used as an indicator for the partial reconstruction of the environment conditions during peatification and coal formation (VASSILEV \& VASSILEVA, 1996, 1998).

\subsection{Affinity of the elements and geochemical associations}

High inorganic affinity $\left(\mathrm{r}_{\mathrm{ash}}=0.7-1.0\right.$; Table 8 ; ESKANAZY et al., 2010; KORTENSKI \& SOTIROV, 2002) is observed for Al, Si, $\mathrm{Ti}, \mathrm{K}, \mathrm{Ba}, \mathrm{Cr}, \mathrm{Ga}, \mathrm{Pb}, \mathrm{Rb}, \mathrm{Sc}, \mathrm{V}, \mathrm{La}, \mathrm{Ce}, \mathrm{Nd}, \mathrm{Sm}, \mathrm{Eu}, \mathrm{Gd}, \mathrm{Ho}$, and $\mathrm{Yb}$ in coal seam I with strong positive correlations with ash yield, as well as for $\mathrm{Al}, \mathrm{Si}, \mathrm{Ti}, \mathrm{Ba}, \mathrm{Cr}, \mathrm{Cu}, \mathrm{Ga}$, In, $\mathrm{Li}, \mathrm{Sc}, \mathrm{Se}, \mathrm{V}, \mathrm{Gd}$ and $\mathrm{Tb}$ in seam II, and for $\mathrm{Al}, \mathrm{Si}, \mathrm{Ti}, \mathrm{Fe}, \mathrm{K}, \mathrm{Na}, \mathrm{Mn}, \mathrm{Ba}, \mathrm{Cd}, \mathrm{Cr}, \mathrm{Ga}$, $\mathrm{Ni}, \mathrm{Sc}, \mathrm{Th}, \mathrm{Zn}, \mathrm{Ce}, \mathrm{Sm}, \mathrm{Eu}, \mathrm{Gd}, \mathrm{Tb}, \mathrm{Ho}, \mathrm{Er}, \mathrm{Yb}$ and Lu in seam III. The strong correlation between ash yield and $\mathrm{Si}, \mathrm{Al}, \mathrm{K}$ and $\mathrm{Na}$ (Table 8, Table S-V of the Supplementary material to this paper) imply the predominance of aluminosilicate and silicate minerals (Fig. 4) in all three seams. As expected, the content of mineral matter from maceral analyses shows a strong correlation with ash yield in all three seams. Elements with a less but still relatively high inorganic affinity $\left(\mathrm{r}_{\mathrm{ash}}=0.5-0.69\right.$; Table 8$)$ include: $\mathrm{Fe}$, $\mathrm{Na}, \mathrm{Cd}, \mathrm{Co}, \mathrm{Li}, \mathrm{Mo}, \mathrm{Ni}, \mathrm{Se}, \mathrm{Th}, \mathrm{Tb}, \mathrm{Dy}, \mathrm{Y}, \mathrm{Er}, \mathrm{Tm}, \mathrm{Lu}$ (in the seam I); $\mathrm{Fe}, \mathrm{K}, \mathrm{Na}, \mathrm{Pb}, \mathrm{Th}, \mathrm{Sm}, \mathrm{Eu}, \mathrm{Ho}, \mathrm{Yb}, \mathrm{Lu}$ (in the seam II) and Li, V, La, Pr, Nd, Dy, Y (in the seam III). Some elements, such as $\mathrm{Mg}, \mathrm{Mn}, \mathrm{As}, \mathrm{Cu}, \mathrm{Zn}$ and $\mathrm{Pb}$, in seam I; Mo, $\mathrm{Zn}$, in seam II; $\mathrm{Mg}$, $\mathrm{Co}, \mathrm{Cu}, \mathrm{Mo}, \mathrm{Pb}, \mathrm{Rb}, \mathrm{Se}$, in seam III, have mixed affinities with

\section{a) GD-601 - Field A}

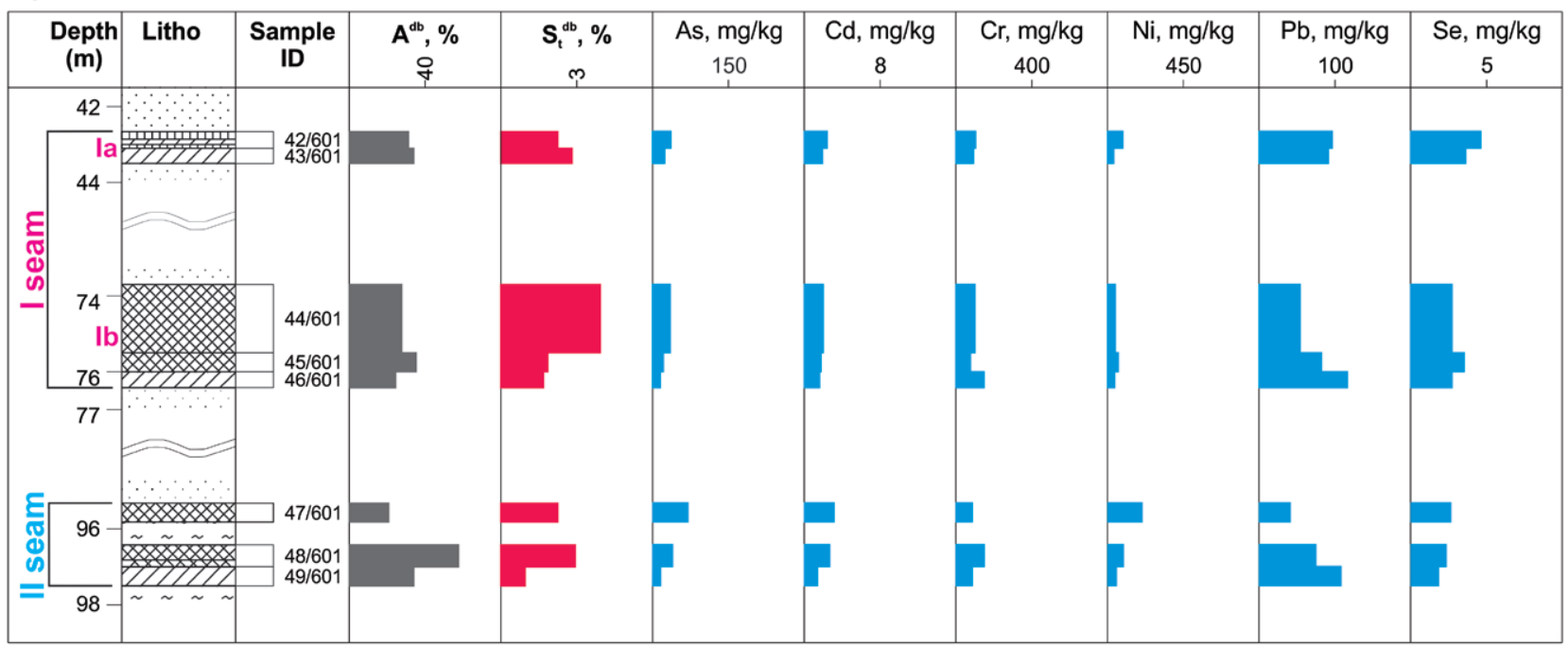

\section{b) GD-603 - Field A}

\begin{tabular}{|c|c|c|c|c|c|c|c|c|c|c|}
\hline $\begin{array}{c}\text { Depth } \\
(\mathrm{m})\end{array}$ & Litho & $\underset{\text { ID }}{\text { Sample }}$ & $\begin{array}{c}\mathrm{A}^{\mathrm{db}}, \% \\
\stackrel{9}{q}\end{array}$ & $\mathbf{S}_{\mathrm{t}}^{\text {db }}, \%$ & $\begin{array}{l}\mathrm{As}, \mathrm{mg} / \mathrm{kg} \\
150\end{array}$ & $\begin{array}{c}\mathrm{Cd}, \mathrm{mg} / \mathrm{kg} \\
8\end{array}$ & $\begin{array}{c}\mathrm{Cr}, \mathrm{mg} / \mathrm{kg} \\
400\end{array}$ & $\begin{array}{c}\mathrm{Ni}, \mathrm{mg} / \mathrm{kg} \\
450\end{array}$ & $\begin{array}{c}\mathrm{Pb}, \mathrm{mg} / \mathrm{kg} \\
100\end{array}$ & $\begin{array}{c}\mathrm{Se}, \mathrm{mg} / \mathrm{kg} \\
5\end{array}$ \\
\hline $\begin{array}{r}39 \\
10 \\
40\end{array}$ & WWm & $\square 50 / 603$ & G & 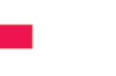 & 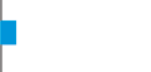 & 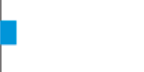 & 1 & I & 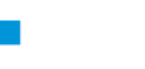 & b \\
\hline 65 & 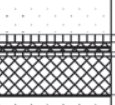 & $\begin{array}{r}-51663 \\
\square \\
532603 \\
531603\end{array}$ & $=$ & & & & & & $=$ & E \\
\hline 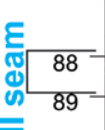 & L & $\begin{array}{r}54603 \\
\quad 55603 \\
56 / 603 \\
\end{array}$ & & $=$ & 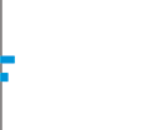 & $F$ & - & 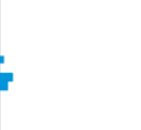 & & E \\
\hline
\end{tabular}

Legend for Litho
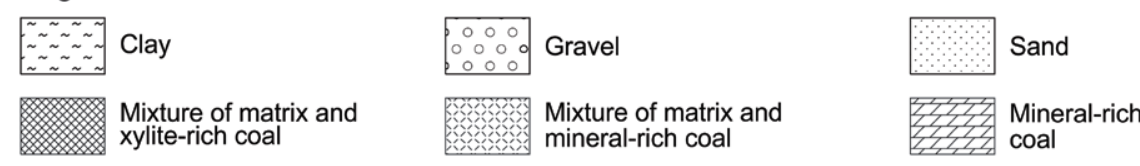

Matrix coal xylite-rich coal 
correlation coefficients varying from 0.35 to 0.49 between ash yield and the aforementioned elements. Sr in seam I; $\mathrm{S}^{\mathrm{db}}$ and $\mathrm{Ca}$ in seam II, and $\mathrm{Ca}$, As and $\mathrm{Sr}$ in seam III show organic affinity $\left(\mathrm{r}_{\mathrm{ash}}=-0.35--1.00\right.$; Table 8$)$.
According to the geochemical and SEM-EDS data most trace elements have good correlation coefficients with $\mathrm{Al}$ and $\mathrm{Si}$ (Table 6), indicating their close connection with silicate and aluminosilicate minerals (quartz, plagioclase, albite, orthoclase, biotite,

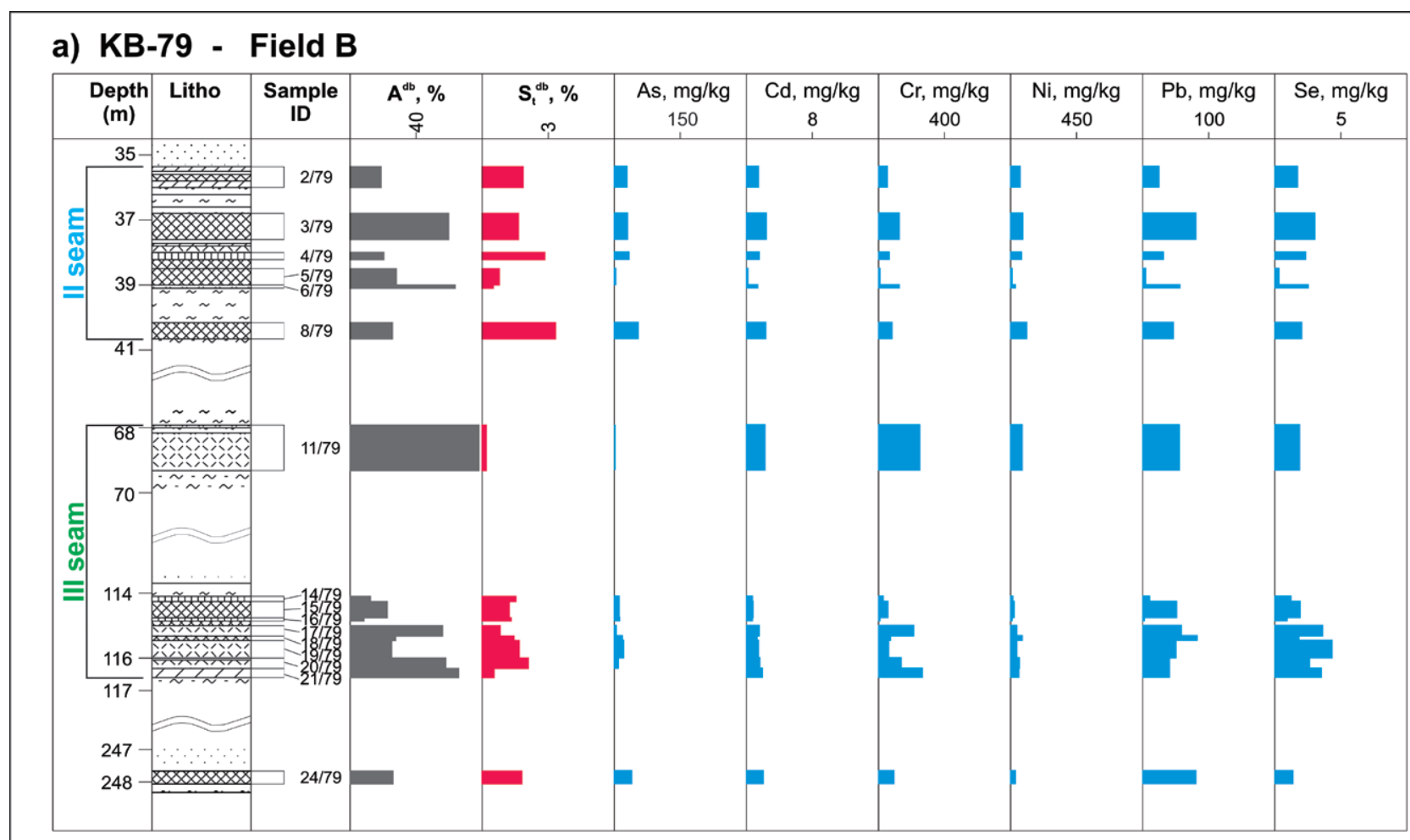

b) KB-91 - Field B

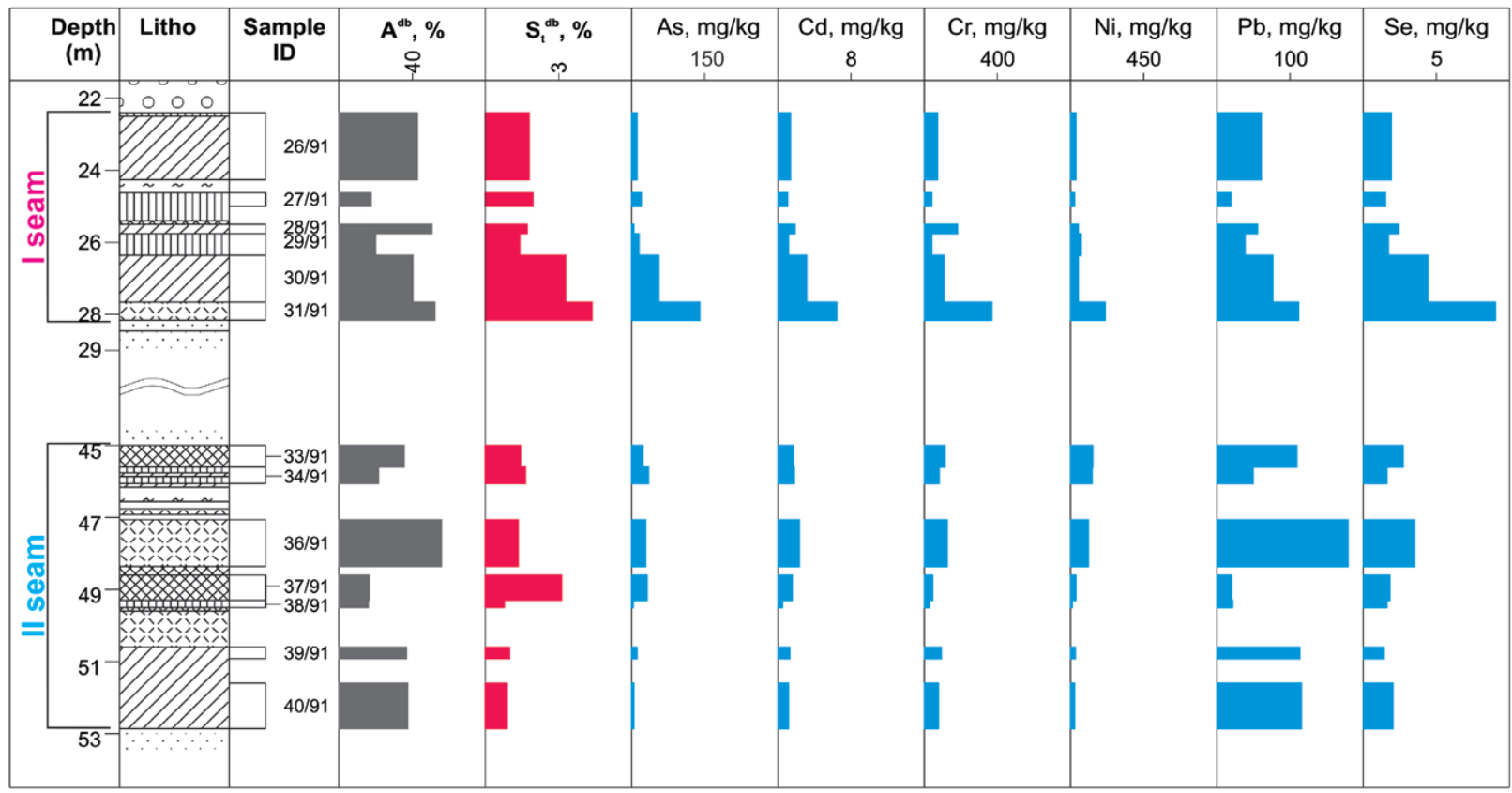

Legend for Litho

\begin{tabular}{|c|c|c|c|c|c|c|c|}
\hline & Clay & 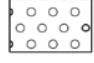 & Gravel & & Sand & Ellla & Matrix coal \\
\hline & $\begin{array}{l}\text { Mixture of matrix and } \\
\text { xylite-rich coal }\end{array}$ & & $\begin{array}{l}\text { Mixture of matrix and } \\
\text { mineral-rich coal }\end{array}$ & 涪勿 & $\begin{array}{l}\text { Mineral-rich } \\
\text { coal }\end{array}$ & & $\begin{array}{l}\text { Xylite-rich } \\
\text { coal }\end{array}$ \\
\hline
\end{tabular}


Table 8. Element affinities deduced from calculation of Pearson's correlation coefficients between the concentration of each element in the coal and ash yield, total sulphur content, Si and Al.

\begin{tabular}{|c|c|c|c|}
\hline & I seam & II seam & III seam \\
\hline \multicolumn{4}{|c|}{ Positive correlation with ash yield } \\
\hline$r_{\text {ash }}=0.7-1.0$ & $\begin{array}{l}\text { Al, Si, Ti, K, } \\
\mathrm{Ba}, \mathrm{Cr}, \mathrm{Ga}, \mathrm{Pb}, \mathrm{Rb}, \mathrm{Sc}, \mathrm{V}, \mathrm{La}, \mathrm{Ce}, \mathrm{Nd}, \mathrm{Sm}, \mathrm{Eu}, \mathrm{Gd}, \\
\mathrm{Ho}, \mathrm{Yb}, \mathrm{LREY}, \mathrm{MREY}, \mathrm{HREY} .\end{array}$ & $\begin{array}{l}\mathrm{Al}, \mathrm{Si}, \mathrm{Ti}, \\
\mathrm{Ba}, \mathrm{Cr}, \mathrm{Cu}, \mathrm{Ga}, \mathrm{Li}, \mathrm{Sc}, \mathrm{Se}, \mathrm{V}, \mathrm{Gd}, \mathrm{Tb} .\end{array}$ & $\begin{array}{l}\mathrm{Al}, \mathrm{Si}, \mathrm{Ti}, \mathrm{Fe}, \mathrm{K}, \mathrm{Na}, \mathrm{Mn}, \mathrm{Ba}, \mathrm{Cd}, \mathrm{Cr}, \mathrm{Ga}, \mathrm{Ni}, \mathrm{Sc} \text {, Th, } \\
\mathrm{Zn}, \mathrm{Ce}, \mathrm{Sm}, \mathrm{Eu}, \mathrm{Gd}, \mathrm{Tb}, \mathrm{Ho}, \mathrm{Er}, \mathrm{Yb}, \mathrm{Lu}, \mathrm{LREY} \\
\text { MREY, HREY. }\end{array}$ \\
\hline$r_{\text {ash }}=0.50-0.69$ & $\begin{array}{l}\text { Fe, Na, } \\
\text { Cd, Co, Li, Mo, Ni, Se, Th, Tb, Dy, Y, Er, Tm, Lu. }\end{array}$ & $\begin{array}{l}\mathrm{Fe}, \mathrm{K}, \mathrm{Na}, \\
\mathrm{Pb}, \mathrm{Th}, \mathrm{Sm}, \mathrm{Eu}, \mathrm{Ho}, \mathrm{Yb}, \mathrm{Lu}, \mathrm{HREY} .\end{array}$ & Li, V, La, Pr, Nd, Dy, Y. \\
\hline$r_{\text {ash }}=0.35-0.49$ & $\begin{array}{l}\mathrm{S}^{\mathrm{db}}, \mathrm{Mg}, \mathrm{Mn} \\
\mathrm{As}, \mathrm{Cu}, \mathrm{Zn}, \mathrm{Pr}\end{array}$ & Mo, Zn. & $\mathrm{Mg}, \mathrm{Co}, \mathrm{Cu}, \mathrm{Mo}, \mathrm{Pb}, \mathrm{Rb}, \mathrm{Se}$ \\
\hline \multicolumn{4}{|c|}{ Negative correlation with ash yield } \\
\hline$r_{\text {ash }}=-0.34-0.34$ & Ca. & $\begin{array}{l}\text { Mg, Mn, } \\
\text { As, Cd, Co, Ni, Rb, Sr, La, Ce, Pr, Nd, Dy, Y, } \\
\text { Er, Tm, LREY, MREY. }\end{array}$ & Tm. \\
\hline$r_{\text {ash }}=-1.0--0.35$ & Sr. & $\mathrm{S}^{\mathrm{db}}, \mathrm{Ca}$ & $\mathrm{Ca}, \mathrm{As}, \mathrm{Sr}$ \\
\hline \multicolumn{4}{|c|}{ Positive correlation with total sulphur content } \\
\hline $\mathrm{r}_{\text {Stot }}=0.7-1.0$ & $\mathrm{Fe}, \mathrm{As}, \mathrm{Cd}, \mathrm{Se}$ & As. & \\
\hline$r_{\text {Stot }}=0.5-0.69$ & $\mathrm{Mn}, \mathrm{Co}, \mathrm{Cr}, \mathrm{Mo}$ & Mo. & Sr. \\
\hline \multicolumn{4}{|l|}{ Al affinity } \\
\hline $\mathrm{r}_{\mathrm{Al}}=0.7-1.0$ & $\begin{array}{l}\mathrm{Si}, \mathrm{Ti}, \\
\mathrm{Cu}, \mathrm{Ga}, \mathrm{Li}, \mathrm{Sc}, \mathrm{Th}, \mathrm{V}, \mathrm{Gd}, \mathrm{Tb} .\end{array}$ & $\begin{array}{l}\mathrm{Si}, \mathrm{Ti}, \mathrm{K}, \\
\mathrm{Ba}, \mathrm{Cr}, \mathrm{Cu}, \mathrm{Ga}, \mathrm{Li}, \mathrm{Pb}, \mathrm{Sc}, \mathrm{Th}, \mathrm{V}, \mathrm{Sm}, \mathrm{Eu}, \mathrm{Gd}, \\
\mathrm{Tb}, \mathrm{Ho},\end{array}$ & $\begin{array}{l}\mathrm{Si}, \mathrm{Ti}, \mathrm{Fe}, \mathrm{K}, \mathrm{Na}, \mathrm{Mn}, \mathrm{Ba}, \mathrm{Cd}, \mathrm{Cr}, \mathrm{Ga}, \mathrm{Li}, \mathrm{Ni}, \mathrm{Sc} \text {, Th, V, } \\
\mathrm{Zn}, \mathrm{Ce}, \mathrm{Pr}, \mathrm{Nd}, \mathrm{Sm}, \mathrm{Eu}, \mathrm{Gd}, \mathrm{Tb}, \mathrm{Dy}, \mathrm{Y}, \mathrm{Ho}, \mathrm{Er}, \mathrm{Yb}, \\
\text { Lu, LREY, MREY, HREY. }\end{array}$ \\
\hline$r_{A l}=0.5-0.69$ & $\begin{array}{l}\mathrm{Mg}, \mathrm{K} \\
\mathrm{Ba}, \mathrm{Pb}, \mathrm{Rb}, \mathrm{Sm}, \mathrm{MREY}\end{array}$ & $\begin{array}{l}\mathrm{Fe}, \mathrm{Na} \text {, } \\
\mathrm{Mo}, \mathrm{Se}, \mathrm{Er}, \mathrm{Yb}, \mathrm{Lu}, \mathrm{HREY} .\end{array}$ & Mg, Co, Cu, Mo, Pb, Se, La. \\
\hline \multicolumn{4}{|l|}{ Si affinity } \\
\hline$r_{\mathrm{Si}}=0.7-1.0$ & $\begin{array}{l}\mathrm{Al}, \mathrm{Ti}, \mathrm{K}, \\
\mathrm{Ba}, \mathrm{Cr}, \mathrm{Ga}, \mathrm{Li}, \mathrm{Pb}, \mathrm{Rb} \\
\mathrm{Sc}, \mathrm{Th}, \mathrm{V}, \mathrm{La}, \mathrm{Ce}, \mathrm{Nd}, \\
\mathrm{Sm}, \mathrm{Gd}, \mathrm{Ho}, \mathrm{LREY}, \mathrm{MREY}\end{array}$ & $\begin{array}{l}\text { Ti, Na, } \\
\mathrm{Ba}, \mathrm{Cr}, \mathrm{Cu}, \mathrm{Ga}, \mathrm{Li}, \mathrm{Sc}, \mathrm{Se}, \mathrm{V}, \mathrm{Gd}, \mathrm{Tb}, \mathrm{Ho} .\end{array}$ & $\begin{array}{l}\text { Ti, Fe, K, } \\
\mathrm{Na}, \mathrm{Mn}, \mathrm{Ba}, \mathrm{Cd}, \mathrm{Cr}, \mathrm{Ga}, \mathrm{Ni}, \mathrm{Sc}, \mathrm{Th}, \mathrm{Ce}, \mathrm{Sm}, \mathrm{Eu}, \mathrm{Gd} \text {, } \\
\text { Tb, Ho, Er, Yb, Lu, MREY, HREY. }\end{array}$ \\
\hline$r_{S i}=0.5-0.69$ & $\begin{array}{l}\mathrm{Fe}, \mathrm{Na} \\
\mathrm{Co}, \mathrm{Ni}, \mathrm{Pr}, \mathrm{Eu}, \mathrm{Tb}, \mathrm{Dy}, \mathrm{Y}, \mathrm{Er}, \mathrm{Tm}, \mathrm{Yb}, \mathrm{Lu}, \mathrm{HREY} .\end{array}$ & $\begin{array}{l}\mathrm{Fe}, \mathrm{K} \\
\mathrm{Pb}, \mathrm{Th}, \mathrm{Sm}, \mathrm{Eu}, \mathrm{Yb}, \mathrm{Lu}, \mathrm{HREY} .\end{array}$ & Li, V, La, Pr, Nd, Dy, Y, LREY. \\
\hline
\end{tabular}

$\mathrm{S}_{\mathrm{db}}$ - total sulphur content, dry basis wt.\%;

Note: Values of the correlation coefficients for individual elements are given in Table S-VI of the Supplementary material to this paper.

and muscovite; Fig. 4) as well as with illite/smectite and chlorite in all coal seams. This result confirms the clastic input in the palaeomire during formation of all coal seams in the Upper Miocene. Pyrite is the most abundant sulphide mineral in the Kovin lignite. A strong positive correlation between sulphur content $\left(\mathrm{r}_{\mathrm{S}-}\right.$ tot $>0.7$; Table 8 ) and Fe, As, Cd, Se, in seam I, As in seam II, as well as a good correlation between sulphur content $\left(\mathrm{r}_{\text {Stot }}=0.5-0.69\right)$ and $\mathrm{Co}, \mathrm{Cr}, \mathrm{Mo}$, in seam I, Mo in seam II and Sr in seam III, imply a close connection with pyrite. The result of SEM-EDS examination confirms the correlation data (Fig. 4k, 1, m). The mineral-rich lignite in the bottom part of seam I of field B is particularly enriched in As (Fig. 4). A very strong correlation between $\mathrm{Fe}$, As and $\mathrm{Cd}$ and all of them with $\mathrm{S}^{\mathrm{db}}$ in seam I, clearly indicates the same origin of these elements and a close connection with pyrite (DAI et al., 2003; DIEHL et al., 2012; FINKELMAN, 1994; YUDOVICH \& KETRIS, 2005a; 2012). Cr, Ni, Pb and $\mathrm{Zn}$ show good correlation with $\mathrm{Si}$ and $\mathrm{Al}$ (Table 8 ) and a most probable connection with aluminosilicate minerals (illite/smectite, chlorite; Fig. 4d). The strong correlation of $\mathrm{Ca}$ and $\mathrm{Sr}$ in seam I shows that $\mathrm{Sr}$ is associated with the carbonate minerals (calcite).

\subsection{Comparison between coal petrology and major and trace elements in coal}

The mineralogical compositions of the Kovin lignites are quite similar, and quartz, illite/smectite, gypsum/anhydrite, plagioclase (albite), haematite, calcite and pyrite are the common minerals for both coalfields. The determined minerals are rich in $\mathrm{Si}$, $\mathrm{Al}$, Ti and $\mathrm{K}$ and they are compatible with the mineralogical composition of the lignite in both fields. Also, the relatively high content of $\mathrm{Fe}$ in the lignite can be related to the high pyrite and hae- matite content, while the high Ca content could be connected with high gypsum/anhydrite and calcite contents.

To further evaluate the relationships between lithotypes, mineralogy and geochemistry, profiles representing the vertical variation in mineralogy were placed alongside profiles of the major element proportions ( $\mathrm{Si}, \mathrm{Al}, \mathrm{Fe}, \mathrm{Ca}, \mathrm{Mg}, \mathrm{Ti}, \mathrm{K}, \mathrm{Na}, \mathrm{Mn}$ ) in the A field (Fig. 2), and the B field (Fig. 3). Profiles representing the vertical variation of the most important trace elements (As, Cd, $\mathrm{Cr}, \mathrm{Ni}, \mathrm{Pb}, \mathrm{Se}$ ) in the Kovin lignite are presented in Figs. 5 and 6 for fields A and B, respectively.

The variations in lithotypes, maceral composition and ash contents (MITROVIĆ et al., 2016) indicate that the water level changed during peat accumulation. Increased ash content (Figs. 5 and 6) may indicate more frequent inundations of the precursor mire resulting in deposition of siliciclastics.

\subsubsection{Coal seam III}

Mineral rich and mixtures of matrix and mineral rich coals with a predominance of detrohuminite, relatively low sulphfur content and higher ash contents in the bottom part of the coal seam III (samples 14/79-21/79; Fig. 3) imply that peat accumulation developed in a freshwater environment of a higher water level of the mire. Organic matter $(\mathrm{OM})$ mainly originates from herbs and shrubs along with aquatic species with a small contribution from conifers (MITROVIĆ et al., 2016). The high Si and Al content in most samples, as well as higher contents of $\mathrm{K}$ and $\mathrm{Na}$ imply deposition of siliciclastic minerals such as quartz with variable amounts of illite/smectite and plagioclase.

The central part of the seam consists of mixtures of xylite and matrix and matrix and mineral rich coals with two thin xy- 
lite-rich layers indicating an unstable water table from higher to lower water level in the mire and less wet conditions. A predominance of detrohuminite with lower ash content confirms decline of water level in the mire. High amounts of inertinite in these samples can be attributed in part to oxidation, but regarding the inertinite-detrohuminite maceral association an allochthonous origin is more probable (TAYLOR et al., 1998; O'KEEFE et al., 2013). A slight increase in the sulphur $\left(\mathrm{S}^{\mathrm{db}}\right)$ and $\mathrm{Ca}$ content suggests input of mineral matter by inflowing sulphate-rich freshwater with the formation of sulphate minerals (gypsum/anhydrite; Fig. 4f) confirmed by mineralogical examination. Two thin xylite-rich coal samples (14/79 and 16/79) with a predominance of telohuminite suggest that deposition of the OM started in a topogenous fresh water mire, which was transformed into a time limited wet forest swamp. The high content of carbonate and sulphate minerals with relatively high $\mathrm{Ca}$ and total sulphur content $\left(\mathrm{S}^{\mathrm{db}}\right)$ indicate the influence of neutral to alkaline groundwater. Furthermore, a good negative correlation coefficient between $\mathrm{Ca}$ and ash content (Table 8; Table S-VI of the Supplementary material to this paper) indicates that $\mathrm{Ca}$ may also be bound with organic matter as exchangeable ions in carboxylic acids and phenolic or hydroxyl groups (LI et al., 2007, 2010; WARD, 2016). Also, its occurrence is possible in metalloporphyrins and other metal-organic compounds (SAXBY, 2000) especially in low-rank coals.

The top of coal seam III (sample 11/79) consists of mixtures of matrix and mineral rich coals with the dominance of detrohuminite. The high ash content as well as the $\mathrm{Si}, \mathrm{Al}, \mathrm{K}$ and $\mathrm{Na}$ contents, associated with an Si/Al ratio of 5.00 (Table S-IV of the Supplementary material to this paper) indicates a higher water level in the mire with deposition of siliciclastic minerals such as quartz and subordinate clay minerals and plagioclase.

Coal from seam III is enriched in $\mathrm{Ba}, \mathrm{Cr}$ and $\mathrm{Sr}$ (Table 6). The high $\mathrm{Cr}$ content was detected in mineral-rich lithotypes with high ash content (Fig. 6). Chromium could be present in coal as both organic and inorganic forms (KETRIS \& YUDOVICH, 2009). In most bituminous coals from the USA two major forms are present (HUGGINS \& HUFFMAN, 2004): organic association and in illite. Cr could be also present in oxide/carbonate/ monosulphide group, and in silicates (DALE et al., 1999). Coals enriched in $\mathrm{Cr}(\geq \sim 100 \mathrm{ppm})$ are usually situated near to ultramafic rocks that contain chrome-bearing spinels (HUGGINS et al., 2000; RUPPERT et al., 1996). In the studied coals, a strong correlation of $\mathrm{Cr}$ with ash content and $\mathrm{Si}, \mathrm{Al}, \mathrm{Ti}, \mathrm{K}$ and $\mathrm{Fe}$ in seam III suggests that the $\mathrm{Cr}$ mainly occurs in aluminosilicate minerals, most probably Cr-rich chlorite (Fig. 4d). The ultramafic rocks which outcrop in the southeastern part of the study area can be the source of $\mathrm{Cr}$ in the studied lignite. Furthermore, a high content of $\mathrm{Cr}, \mathrm{Ni}$ and other elements detected in lignite from the Drmno field (Fig. 1; ŽIVOTIĆ et al., 2015) suggests a similar source. The strong correlation of $\mathrm{Ba}$ with ash content suggests an inorganic form probably as barite (Fig. 4g), while Sr indicates an organic form (Table 8). The results of the chemical and mineralogical investigation of the Kovin lignite samples indicate an organic form of As in seam III.

\subsubsection{Coal seam II}

The geochemical composition of coal seam II shows some differences between fields A and B. Organic matter of the lignites from both coalfields was derived from herbs and shrubs with variable amounts of woody vegetation (MITROVIĆ et al., 2016). Matrix and mixtures of matrix and mineral rich coals with a slight predominance of detrohuminite over telohuminite built the bottom part of seam II in field A (samples 48/601, 49/601, 55/603, 56/603; Fig. 2). The coal is characterised by moderate to very high ash and a low to moderate sulphur content. The high $\mathrm{Si}, \mathrm{Al}, \mathrm{K}$, and $\mathrm{Na}$ contents suggest a high contribution from siliciclastic sediments. The upper part of seam II in field A consists of xylite-rich coal (54/603), with moderate amounts of ash and sulphur. The $\mathrm{Si} / \mathrm{Al}$ ratio is still high, as well as the amounts of $\mathrm{Ca}$ and $\mathrm{Fe}$, suggesting a greater contribution of siliciclastic sediments with variable amounts of Fe-oxide/hydroxides (Fig. 4h). An outstanding negative correlation between $\mathrm{Ca}$ and sulphur content $\left(\mathrm{S}^{\mathrm{db}}\right)$, as well as with ash content (Table 8) suggests the organic affinity of $\mathrm{Ca}$ and S. According to previous research (CHOU, 2012; LI et al., 2007, 2010; WARD, 2016) in neutral to alkaline groundwater $\mathrm{Ca}$ and $\mathrm{S}$ could be taken by peat forming plants in the palaeomire and bound with organic matter.

Xylite-rich and mixtures of xylite-rich and matrix coals with prevalence of telohuminite occur in the bottom part of coal seam II in field B (samples 39-40/91, 8/79; Fig. 3). Lignite is characterised by moderate ash and low to high sulphur contents with variable $\mathrm{Si}$ and $\mathrm{Al}$ followed by higher $\mathrm{Ca}$ and Fe contents, suggesting a higher contribution of siliciclastic sediments with variable amounts of Fe-oxide/hydroxides and sulphates. The central part of seam II is characterised by moderate to high ash and a low/ moderate to high sulphur content with variable content of major elements. The higher $\mathrm{Ca}$ and $\mathrm{Fe}$ contents in xylite-rich samples $(4 / 79,37 / 79)$ suggest a higher contribution of sulphates and Feoxide/hydroxides formed in a neutral to alkaline and probably oxic environment. Matrix and mixtures of matrix and xylite-rich coal with moderate contents of ash and sulphur built up the upper part of seam II. Higher contents of $\mathrm{Si}$ and $\mathrm{Al}$ in borehole KB-91 (samples 33/91, 34/91) indicate a higher contribution of siliciclastic sediments, while the higher contents of $\mathrm{Ca}$ and total sulphur in borehole KB-79 (sample 2/79) may suggest a slight predominance of sulphate minerals and changes in water level and the paleoenvironment.

The content of $\mathrm{As}, \mathrm{Cr}, \mathrm{Ni}, \mathrm{Pb}, \mathrm{V}$ and $\mathrm{Zn}$ in seam II coal is several times higher in comparison with the Clarke values for brown coal (KETRIS \& YUDOVICH, 2009). Arsenic could be present in pyrite (DAI et al., 2003; DIEHL et al., 2012; FINKELMAN, 1994; KOLKER, 2012 YUDOVICH \& KETRIS, 2005a, and references therein) but also as the arsenate ion in clays or phosphate minerals (SWAINE, 1990). Organic bound arsenic is also common, with higher contents in lower organisms, algae and herbages than in seed plants, ferns, and moss (LIU et al., 2003). Three dominant forms of As in coal (YUDOVICH \& KETRIS, $2005 \mathrm{a}, \mathrm{b}$ ) are pyritic, organic and arsenate. Recent research on As rich coals from the Xishanyao formation, China (ZHANG et al., 2018) confirms sulphfide bound, residual form, organic bound and adsorption solution of arsenic. The same authors conclude that the geological origins leading to the enrichment of arsenic in coal are: hydrothermal solution activities controlled by the tectonic fracturing of the region, sources of terrigenous detrital material controlled by regional geological settings with the distribution of elements and type of plants in the paleomire. The results of the chemical and mineralogical investigation of the Kovin lignite samples indicate a pyritic form of As in seam II. A strong correlation of $\mathrm{Cr}$ with $\mathrm{Si}, \mathrm{Al}, \mathrm{Ti}$ and $\mathrm{Fe}$ in seam II, suggests that the $\mathrm{Cr}$ mainly occurs in aluminosilicate minerals. Nickel could be present in coal in organic and inorganic form. It can be associated with clays (kaolinite, illite, smectite) and sulphides (pyrite, millerite, bravoite; YUDOVICH \& KETRIS, 2005b). Organically bound Ni is also common in coal (RUPPERT et al., 1996). Nickel 
in seam II of the Kovin deposit shows no specific affinity, indicating both organic and mineral associations. Lead mainly occurs as sulphide (galena) or associated with sulphide minerals (FINKELMAN, 1994), as well as lead selenide in coals (HOWER \& ROBERTSON, 2003). It could also be present in silicates (DALE et al., 1999). Kovin lignite in seam II has a Pb content that is several times higher content than the Clarke value for brown coals (KETRIS \& YUDOVICH, 2009). The positive correlations of $\mathrm{Pb}$ with $\mathrm{Si}, \mathrm{Al}, \mathrm{Ti}$ and $\mathrm{K}$ in all seams indicate the presence of $\mathrm{Pb}$ in the clay minerals.

\subsubsection{Coal seam I}

Lignite from seam I from the A field shows some differences between the lower (Ib) and upper (Ia) layers. The lower part of the Ib layer (samples 44/601-46/601 and 51/603-53/603), made of a mixture of matrix and xylite-rich coal, has variable amounts of $\mathrm{Si}$ and $\mathrm{Al}$, with high contents of $\mathrm{Ca}$, Fe and $\mathrm{Mn}$ in samples 45/601 and $52 / 603$, followed by a higher $\mathrm{Si} / \mathrm{Al}$ ratio. The lignite from the Ib layer is characterised by moderate to high ash and sulphur contents, while the upper (Ia) layer is characterised by moderate ash and sulphur contents and variable amounts of $\mathrm{Ca}$ and $\mathrm{Fe}$ with a higher $\mathrm{Si} / \mathrm{Al}$ ratio, which is compatible with a higher contribution of siliciclastic sediments.

The characteristics of lignite in seam I of the B field (samples 26/91-31/91) revealed that mineral matter in the matrix coal consists of siliciclastic sediments, while xylite-rich coal has higher $\mathrm{Ca}, \mathrm{Fe}$ and $\mathrm{Mn}$ contents. The lignite is characterised by moderate to high ash and sulphur contents indicating an unstable water table with frequent flooding. The highest sulphur (4.40\%; Table S-II of the Supplementary material to this paper) and ash contents are identified in the lowermost, mineral rich sample (31/79; Fig. 4b), which is also enriched in Fe (Fig. 7b). The good correlation between sulphur and Fe contents (Table 8 ) is commensurate with pyrite as the main source of both elements $\left(\mathrm{Fe}, \mathrm{S}^{\mathrm{db}}\right)$ in seam I. That part of seam I is especially enriched in $\mathrm{As}, \mathrm{Cd}, \mathrm{Cr}, \mathrm{Ni}, \mathrm{Pb}$ and Se with the highest value of As $(140.0 \mathrm{mg} / \mathrm{kg}), \mathrm{Cd}(6.5 \mathrm{mg} /$ $\mathrm{kg}), \mathrm{Cr}(371.4 \mathrm{mg} / \mathrm{kg})$, Ni $(214.0 \mathrm{mg} / \mathrm{kg})$ and $\mathrm{Se}(9.0 \mathrm{mg} / \mathrm{kg})$. In comparison with the Clarke value for brown coal (KETRIS \& YUDOVICH, 2009) these values are 18, 27, 25, 24 and 9 times higher for $\mathrm{As}, \mathrm{Cd}, \mathrm{Cr}, \mathrm{Ni}, \mathrm{Pb}$ and Se respectively. A very strong correlation As- $\mathrm{S}^{\mathrm{db}}$ (Table 6) indicates a pyritic form of As in coal seam I. Cadmium is predominantly associated with $\mathrm{Zn}$ mostly in sphalerite (ZnS; GOODARZI, 2002), as well as in other sulphides (e.g. pyrite; DALE et al., 1999). However, an "organic" form of $\mathrm{Cd}$ is also possible (YUDOVICH et al., 1985). The very strong correlation of $\mathrm{Cd}-\mathrm{S}^{\mathrm{db}}$ (Table 8), $\mathrm{Cd}-\mathrm{Fe}(\mathrm{r}=0.97)$ clearly indicates the close connection of $\mathrm{Cd}$ with pyrite in seam I. Selenium could be present in organic and inorganic form (YUDOVICH \& KETRIS, 2005b, 2006). In high sulphur coals, Se is concentrated in sulphide minerals (pyrite) and some selenitic forms (clausthalite, $\mathrm{PbSe}$ ). In oxidized coals, Se is enriched in the bed oxidation zones (YUDOVICH \& KETRIS, 2006), with U, Fe, Mo, V, and Pb. The strong correlation of Se with $\mathrm{S}^{\mathrm{db}}(\mathrm{r}=0.76)$ supports their occurrences in pyrite.

The results of the chemical and mineralogical investigation of the Kovin lignite samples indicate a pyritic form of As, Cd, $\mathrm{Co}, \mathrm{Cr}, \mathrm{Mo}$, Se in seam I (Table 8; Fig. 4k, 1, m) formed in presumably neutral and anaerobic conditions in the palaeomire. The very strong correlation of $\mathrm{Fe}$ with $\mathrm{As}(\mathrm{r}=0.94), \mathrm{Cd}(\mathrm{r}=0.97)$, Co $(\mathrm{r}=0.82), \mathrm{Cr}(\mathrm{r}=0.91), \mathrm{Ni}(\mathrm{r}=0.87), \mathrm{Se}(\mathrm{r}=0.91)$, and As with $\mathrm{Cd}$ $(\mathrm{r}=0.96), \mathrm{Co}(\mathrm{r}=0.79), \mathrm{Cr}(\mathrm{r}=0.79), \mathrm{Ni}(\mathrm{r}=0.81)$, Se $(\mathrm{r}=0.93)$ con- firms the close interrelation of the aforementioned elements with pyrite. The distribution and enrichment of elements was presumably controlled by conditions during peat accumulation. A higher water level in a palaeomire with increases in clastic inputs resulted in high concentrations of aluminosilicate minerals. Surface- and groundwater from the surrounding palaeo-environment, rich in elements such as $\mathrm{As}, \mathrm{Cd}, \mathrm{Co}, \mathrm{Cr}, \mathrm{Ni}$, Se, derived from the weathering and leaching of the basement rocks, along with a reducing environment in the palaeomire, may have resulted in the formation of syngenetic pyrite enriched in some elements, as $\mathrm{As}$, Se, and $\mathrm{Sb}$ may be substituted with $\mathrm{S}$ in the pyrite structure (KOLKER, 2012).

\section{CONCLUSION}

The Upper Miocene Kovin sedimentary sequence consists of shallow, caspi-brackish to fresh water clastic sediments (sand and silt with thin clay, carbonaceous clay and gravel layers), with three lignite seams, III, II and I (from lowest to highest).

Huminite is the prevailing maceral group in the three coal seams. The most abundant maceral subgroups are telohuminite and detrohuminite with variable amounts of gelohuminite. Liptinite and inertinite are much less abundant. The content of mineral matter varies between 3 and 37 vol. \%. Clays are the most abundant, while pyrite, carbonates and other minerals are less abundant.

SEM-EDS examination revealed that the most abundant minerals in all the studied lignite samples from all coal seams are clays (illite/smectite), silicates (quartz, plagioclase), sulphate (gypsum/anhydrite) and carbonate (calcite). The other iron-rich minerals are sulphides, oxides and hydroxides (pyrite, magnetite, haematite, and limonite). Minor minerals such as rutile, ilmenite, K-feldspar (albite, orthoclase), and mica, were detected in all coal seams. In addition, barite, chlorite, epidote, allanite and zircon were also detected in coal seam I. Sphalerite, galena, siderite, dolomite, ankerite and monazite were identified in coal seam II, while barite and monazite were found in coal seam III.

According to the mineralogical and geochemical data, silicate and aluminosilicate minerals (quartz, plagioclase, albite, orthoclase, biotite, and muscovite) together with illite/smectite and chlorite are the main carriers of $\mathrm{Si}, \mathrm{Al}, \mathrm{Na}$ and $\mathrm{K}$ in all coal seams.

The lignite from the Kovin deposit is enriched in $\mathrm{As}, \mathrm{Cd}, \mathrm{Co}$, $\mathrm{Cr}, \mathrm{Cu}, \mathrm{Ga}, \mathrm{Li}, \mathrm{Mn}, \mathrm{Mo}, \mathrm{Ni}, \mathrm{Pb}, \mathrm{V}, \mathrm{Zn}, \mathrm{Gd}, \mathrm{Tb}, \mathrm{Er}$ and $\mathrm{Lu}$ in comparison with the Clarke values for brown coals. Almost all of these elements demonstrate a strong inorganic affinity, but some of them (As, Ca, S, Sr) also have an outstanding organic affinity. A group of elements in seam II are both inorganically and organically bound.

The results of the correlation analysis indicate a pyritic form of $\mathrm{As}$ and $\mathrm{Cd}$ in seam I, and an organic form in seam III. Cr, $\mathrm{Pb}$ and Se occur in aluminosilicate minerals in all three coal seams. $\mathrm{Ni}$ is associated with sulphides in coal seam I, aluminosilicates in coal seam III, whereas no specific affinity is observed for this element in coal seam II. Despite the high concentrations, $\mathrm{Zn}$ does not show specific affinity in all coal seams.

\section{ACKNOWLEDGEMENT}

This work was financed by the Ministry of Education and Science of the Republic of Serbia (Projects No. OI176006, OI176016 and OI172035), which is gratefully acknowledged. We are also grateful to the anonymous reviewers whose helpful suggestions and comments greatly benefited this paper. 


\section{REFERENCES}

BASIC GEOLOGICAL MAP OF SERBIA: http://geoliss.mre.gov.rs/OGK/RasterSrbija (last accessed June 4, 2018).

CHATZIAPOSTOLOU, A., KALAITZIDIS, S., PAPAZISIMOU, S., CHRISTANIS, K., \& VAGIAS, D. (2006): Mode of occurrence of trace elements in the Pellana lignite (SE Peloponnese, Greece).- International Journal of Coal Geology, 65, 3-16. doi: 10.1016/j.coal.2005.04.005

CHOU, C.L. (2012): Sulfur in coals: a review of geochemistry and origins.- International Journal of Coal Geology, 100, 1-13. doi: 10.1016/j.coal.2012.05.009

CHRISTANIS, K., GEORGAKOPOULOS, A., FERNÁNDEZ-TURIEL, J.L. \& BOUZINOS, A. (1998): Geological factors influencing the concentration of trace elements in the Philippi peatland, eastern Macedonia, Greece.- International Journal of Coal Geology, 36, 295-313.

DAI, S., HOU, X., REN, D. \& TANG, Y. (2003): Surface analysis of pyrite in the No. 9 coal seam, Wuda Coalfield, Inner Mongolia, China, using high-resolution time-offlight secondary ion mass-spectrometry.- International Journal of Coal Geology, 55, 139-150. doi: 10.1016/S0166-5162(03)00109-5

DAI, S., REN, D., CHOU, C.-L., FINKELMAN, R.B., SEREDIN, V.V. \& ZHOU, Y. (2012): Geochemistry of trace elements in Chinese coals: a review of abundances, genetic types, impacts on human health, and industrial utilization.- International Journal of Coal Geology, 94, 3-21. doi: 10.1016/j.coal.2011.02.003

DALE, L.S., CHAPMAN, J.F., BUCHANAN, S.J. \& LAVRENCIC, S.A. (1999): Mechanisms for Trace Element Partitioning in Australian Coals - Project 4.2 - Final Report, Co-operative Research Centre for Black Coal Utilisation.

DAVIDSON, R.M. (2000): Modes of Occurrence of Trace Elements in Coal; Results from an International Collaborative Program.- IEA Coal Research, London.

DIEHL, S.F., GOLDHABER, M.B., KOENIG, A.E., LOWERS, H.A. \& RUPPERT, L.F. (2012): Distribution of arsenic, selenium, and other trace elements in high pyrite Appalachian coals: Evidence for multiple episodes of pyrite formation.- International Journal of Coal Geology, 94, 238-249. doi: 10.1016/j.coal.2012.01.015

ELECTRIC POWER SYSTEM OF SERBIA (EPS, 2018) - http://www.eps.rs (last accessed June 4, 2018).

ERCEGOVAC, M., ŽIVOTIĆ, D. \& KOSTIĆ, A. (2006): Genetic-Industrial Classification of Brown Coals in Serbia.- International Journal of Coal Geology, 68, 39-56.

ESKANAZY, G.M., FINKELMAN, R.B. \& CHATTARJEE, S. (2010): Some considerations concerning the use of correlation coefficients and cluster analysis in interpreting coal geochemistry data.- International Journal of Coal Geology, 83, 491493. doi: 10.1016/j.coal.2010.05.006

FILIPPIDIS, A., GEORGAKOPOULOS, A., KASSOLI-FURNARAKI, A., MISAELIDIS, P., YIAKKOUPIS, P. \& BROUSSOULIS, J. (1996): Trace elements contents in composited samples of three lignite seams from the central part of the Drama lignite deposit, Macedonia, Greece.- International Journal of Coal Geology, 29, 219-234. doi: 10.1016/0166-5162(95)00032-1

FINKELMAN, R.B. (1994): Modes of occurrence of potentially hazardous elements in coal: levels of confidence.- Fuel Procesing Technology, 39, 21-34. doi: 10.1016/ 0378-3820(94)90169-4

FINKELMAN, R.B., OREM, W., CSTRANOVA, V., TATU, C.A., BELKIN, H.E., ZHENG, B., LERCH, H.E., MAHARAJ, S.V. \& BATES, A.L. (2002): Health impacts of coal and coal use: possible solutions.- International Journal of Coal Geology, 50, 425- 443. doi: 10.1016/S0166-5162(02)00125-8

FINKELMAN, R.B., PALMER, C.A. \& WANG, P. (2018): Quantification of the modes of occurrence of 42 elements in coal.- International Journal of Coal Geology, 185, 138-160. doi: 10.1016/j.coal.2017.09.005

FOSCOLOS, A.E., GOODARZI, F., KOUKOUZAS, C.N. \& HATZIYIANNIS, G. (1998): Assessment of environmental impact of coal exploration and exploitation in the Drama basin, northeastern Greek-Makedonia.- Energy Sources, 20, 795820.

GENTZIS, T., GOODARZI, F., KOUKOUZAS, C. \& FOSCOLOS, A. (1996): Petrology, mineralogy, and geochemistry of lignites from Crete, Greece.- International Journal of Coal Geology, 30, 131-150. doi: 10.1016/0166-5162(95)00034-8

GENTZIS, T., GOODARZI, F. \& FOSCOLOS, A.E. (1997): Geochemistry and mineralogy of Greek lignites from Ioannina basin.- Energy Sources, 19, 111-128. doi: 10.1080/00908319708908837

GEORGAKOPOULOS, A. (2001): Trace elements in the lava xylite/lignite deposit, Servia basin, Northern Greece.- Energy Sources, 23, 143-156. doi: 10.1080/ 00908310151092335

GLUSKOTER, H. (1975): Mineral matter and trace elements in coal.- In: BABU, S. (ed.): Trace Elements in Fuel. Am. Chem. Soc., Washington, 1-22. doi: 10.1021/ ba-1975-0141.ch001

GOODARZI, F. (2002): Mineralogy, elemental composition and modes of occurrence of elements in Canadian feed-coals.- Fuel, 81, 1199-1213. doi: 10.1016/S00162361(02)00023-6

GÜRDAL, G. (2011): Abundances and modes of occurrence of trace elements in the Çan coals (Miocene), Çanakkale-Turkey.- International Journal of Coal Geology, 87, $157-173$.
HOWER, J.C. \& ROBERTSON, J.D. (2003): Clausthalite in coal.- International Journal of Coal Geology, 53, 219-225. doi: 10.1016/S0166-5162(03)00022-3

HUGGINS, F.E. \& HUFFMAN, G.P. (2004): How do lithophile elements occur in organic association in bituminous coals? - International Journal of Coal Geology, 58, 193-204. doi: 10.1016/jcoal.2003.10.009

HUGGINS, F.E., SHAH, N., HUFFMAN, G.P., KOLKER, A., CROWLEY, S., PALMER, C.A. \& FINKELMAN, R.B. (2000): Mode of occurrence of chromium in four US coals.-Fuel Processing Technology, 63, 79-92. doi: 10.1016/j.coal.2003. 10.009

INTERNATIONAL COMMITTEE FOR COAL PETROLOGY (ICCP), (2001): The new inertinite classification (ICCP System 1994).- Fuel, 80, 459-471.

INTERNATIONAL COMMITTEE FOR COAL PETROLOGY (ICCP), (1993): http:// www.iccop.org/documents/1993-iccp-international-handbook-of-coal-petrography-3rd-suppl-to-2nd-ed-pdf.pdf (last accessed June 4, 2018).

INTERNATIONAL STANDARD ORGANIZATION (ISO) 1171 (1997): Methods for analysis and testing of coal and coke. Determination of ash content.- International Organization for Standardization, Switzerland (10 p).

INTERNATIONAL STANDARD ORGANIZATION (ISO) 7404-2 (2009): Methods for the Petrographic Analysis of Coals-Part 2: Methods of Preparing Coal Samples.- International Organization for Standardization, Geneva, Switzerland (12 p).

ISO 7404-3 (2009): Methods for the petrographic analysis of coals - Part 3: Method of determining maceral group composition.- Organization for Standardization, Switzerland (7 p).

KALAITZIDIS, S., CHRISTANIS, K., GEORGAKOPOULOS, A., FERNÁNDEZ-TURIEL, J.L. \& PAPAZISIMOU, S. (2002): Influence of geological conditions during peat accumulation on trace element affinities and their behavior during peat combustion.- Energy Fuel, 16, 1476-1482. doi: 10.1021/ef0200673

KARAYIGIT, A.I. \& GAYER, R.A. (2000): Trace elements in a Pliocene-Pleistocene lignite profile from the Afşin-Elbistan field, Eastern Turkey.- Energy Sources, $22 / 1,13-21$.

KARAYIGIT, A.I., GAYER, R.A., QUEROL, X. \& ONACAK, T. (2000): Contents of major and trace elements in feed coals from Turkish coal fired power plants. - International Journal of Coal Geology, 44, 169-184. doi: 10.1016/S0166-5162(00) 00009-4

KARAYIGIT, A.I., GAYER, R.A., ORTAC, E.F. \& GOLDSMITH, S. (2001): Trace elements in the Lower Pliocene fossiliferous Kangal lignites, Sivas, Turkey.- International Journal of Coal Geology, 47/2, 73-89. doi: 10.1016/S0166-5162(01)00030-1

KETRIS, M.P. \& YUDOVICH, YA.E. (2009): Estimations of Clarkes for carbonaceous biolithes:world averages for trace element contents in black shales and coals.- International Journal of Coal Geology, 78, 135-148.

KOLKER, A. (2012): Minor element distribution in iron disulfides in coal: a geochemical review.- International Journal of Coal Geology, 94, 32-43. doi: 10.1016/j. coal.2011.10.011

KORTENSKI, J. \& SOTIROV, A. (2002): Trace and major element content and distribution in Neogene lignite from the Sofia Basin, Bulgaria.- International Journal of Coal Geology, 52, 63-82. doi: 10.1016/S0166-5162(02)00133-7

KOSTOVA, I. \& ZDRAVKOV, A. (2007): Organic petrology, mineralogy and depositional environment of the Kipra lignite seam, Maritza-West basin, Bulgaria.- International Journal of Coal Geology, 71, 527-541. doi: 10.1016/j.coal.2006.06.006

KOVIN MINE - OFFICIAL WEB SITE: http://www.rudnikkovin.rs/wp (last accessed June 4, 2018).

KOUKOUZAS, N., WARD, C. \& LI, Z. (2010): Mineralogy of lignites and associated strata in the Mavropigi field of the Ptolemais Basin, northern Greece.- International Journal of Coal Geology, 81, 182-190. doi: 10.1016/j.coal.2009.12.012

LI, Z., WARD, C.R. \& GURBA, L.W. (2007): Occurrence of non-mineral inorganic elements in low-rank coal macerals as shown by electron microprobe element mapping techniques.- International Journal of Coal Geology, 70, 137-149. doi: 10. 1016/j.coal.2006.04.009

LI, Z., WARD, C.R. \& GURBA, L.W. (2010): Occurrence of non-mineral inorganic elements in macerals of low-rank coals.- International Journal of Coal Geology, 81, 242-250. doi: 10.1016/j.coal.2009.02.004

LIU, G.J., YANG, P., PENG, Z. \& WANG, G. (2003): Geochemistry of trace elements from the no. 3 coal seam of Shanxi formation in the Yanzhou mining district.- Geochimica, 32, 55-62.

MAGYAR, I., GEARY, D.H. \& MÜLLER, P. (1999): Paleogeographic evolution of the Late Miocene Lake Pannon in Central Europe.- Palaeogeography, Palaeoclimatology, Palaeoecology, 147, 151-167. doi: 10.1016/S0031-0182(98)00155-2

MAGYAR, I., RADIVOJEVIĆ, D., SZTANÓ, O., SYNAK, R., UJSZÁSZI, K. \& PÓCSIK, M. (2013): Progradation of the paleo-Danube shelf margin across the Pannonian Basin during the Late Miocene and Early Pliocene.- Global Planetary Change, 103, 168-173. doi: 10.1016/j.gloplacha.2012.06.007

MEIJ, R. (1995): The distribution of trace elements during the combustion of coal.- In: SWAINE, D.J. \& GOODARZI, F. (eds.): Environmental Aspects of Trace Elements in Coal.- Kluwer Academic Publication, Dordrecht, the Netherlands, 111127. doi: 10.1007/978-94-015-8496-8_7 
MILIVOJEVIĆ, J. \& ŽIVOTIĆ, D. (2006): Genesis of Coal from the Kovin Deposit Based on the Palynological and Petrographic Composition.- The $7^{\text {th }}$ European Paleobotanical and Palynological Conference, September 6-11, Prague, Czech Republic, Abstracts, 94 (ISBN 80-7036-200-6).

MITROVIĆ, D., ĐOKOVIĆ, N., ŽIVOTIĆ, D., BECHTEL, A., ŠAJNOVIĆ, A. \& STOJANOVIĆ, K. (2016): Petrographical and organic geochemical study of the Kovin lignite deposit, Serbia.- International Journal of Coal Geology, 168, 80-107. doi: 10.1016/j.coal.2016.07.008

MITROVIĆ, D., ĐOKOVIĆ, N., ŽIVOTIĆ, D., BECHTEL, A., CVETKOVIĆ, O. \& STOJANOVIĆ, K. (2017): Characterization of lignite lithotypes from the "Kovin" deposit (Serbia) - Implications from petrographic, biomarker and isotopic analysis.- Journal of the Serbian Chemical Society, 82, 739-754.

O'KEEFE, J.M.K., BECHTEL, A., CHRISTANIS, K., DAI, S., DI MICHELE, W.A., EBLE, C.F., ESTERLE, J.S., MASTALERZ, M., RAYMOND, A.L., VALENTIM, B.V., WAGNER, N.J., WARD, C.R. \& HOWER, J.C. (2013): On the fundamental difference between coal rank and coal type.- International Journal of Coal Geology, 118, 58-87. doi: 10.1016/j.coal.2013.08.007

PALMER, C.A., TUNCALI, E., DENNEN, K.O., COBURN, T.C. \& FINKELMAN, R.B. (2004): Characterization of Turkish coals: a nationwide perspective.- International Journal of Coal Geology, 60, 85-115. doi: 10.1016/j.coal.2004.05.001

PAVLOVIĆ, M. (1959): Contribution for stratigraphy of Neogene sediments in the Kovin-Gaj and Ovča (Banat) area.- Annales Géologiques de la Péninsule Balkanique, 26, 141-149 (in Serbian with German abstract).

PICKEL, W., KUS, J., FLORES, D., KALAITZIDIS, S., CHRISTANIS, K., CARDOTT, B.J., MISZ-KENNAN, M., RODRIGUES, S., HENTSCHEL, A., HAMOR-VIDO, M., CROSDALE, P. \& WAGNER, N. (2017): Classification of liptinite - ICCP System 1994.- International Journal of Coal Geology, 169, 40-61. doi: 10.1016/j.coal.2016.11.004

QUEROL, X., WHATELEY, M.K.G., FERNÁNDEZ-TURIEL, J.L. \& TUNCALI, E. (1997): Geological controls on the mineralogy and geochemistry of the Beypazari lignite, Central Anatolia, Turkey.- International Journal of Coal Geology, 33/3, 255-271. doi: 10.1016/S0166-5162(96)00044-4

RIETVELD, H.M. (1969): A profile refinement method for nuclear and magnetic structures.- Journal of Applied Crystallography, 2, 65-71. doi: 10.1107/ S0021889869006558

RODRÍGUEZ-CARVAJAL, J. (1993): FullProf Suite: Crystallographic tools for Rietveld, profile matching \& integrated intensity refinements of X-ray and/or neutron data. http://www.ill.eu/sites/fullprof/.

RÖGL, F. (1996): Stratigraphic correlation of the Paratethys Oligocene and Miocene. Mitteilungen der Gesellschaft der Geologie und Bergbaustudenten in Wien, 41, $65-73$.

RUPPERT, L., FINKELMAN, R., BOTI, E., MILOSAVLJEVIĆ M., TEWALT, S., SIMON, N. \& DULONG, F. (1996): Origin and significance of high nickel and chromium concentrations in Pliocene lignite of the Kosovo Basin, Serbia.- International Journal of Coal Geology, 29, 235-258. doi: 10.1016/0166-5162(95)00031-3

SAXBY, J.D. (2000): Minerals in coal.- In: GLIKSON, M. \& MASTALERZ, M. (eds.): Organic Matter and Mineralisation: Thermal Alteration, Hydrocarbon Generation, and Role in Metallogenesis. Kluwer Academic, Dordrecht, 314-328.doi: 10.1007/ 978-94-015-9474-5_15

SEREDIN, V.V. (2010): A new method for primary evaluation of the outlook for rare earth element ores.- Geology of Ore Deposits, 52, 428-433. doi: 10.1134/ S1075701510050077

SEREDIN, V.V. \& DAI, S. (2012): Coal deposits as a potential alternative source for lanthanides and yttrium.- International Journal of Coal Geology, 94, 67-93. doi: 10.1016/j.coal.2011.11.001

SPAJIĆ-MILETIĆ, O. (1960): Overview of the Sarmatian and Pannonian ostracod fauna in the Mlava basin and Sopotska greda.- Annales Géologiques de la Péninsule Balkanique, 27, 253-264 (in Serbian with German abstract).

SPAJIĆ-MILETIĆ, O. (1969): Biostratigraphy of the Upper Miocene.- Annales Géologiques de la Péninsule Balkanique, 34, 11-19 (in Serbian with German abstract).

SRPS B.H8.317:1988, (1988): Methods of analysis of coal and coke - Determination of volatile matter content.- Institute for Standardization of Serbia, Belgrade, Serbia, 6 p. (in Serbian).

SRPS B.H8.318:1972, (1972): Methods of analysis of coal and coke - Determination of gross calorific value by the calorimetric bomb method, and calculation of net calorific value.- Institute for Standardization of Serbia, Belgrade, Serbia, 11 p. (in Serbian).

SRPS B.H8.338:1986, (1986): Coal and coke - Determination of total moisture content - Gravimetric method.- Institute for Standardization of Serbia, Belgrade, Serbia, $5 \mathrm{p}$. (in Serbian).

SRPS B.H8.390:1987, (1987): Brown coals and lignites - Determination of moisture content - Indirect gravimetric method.- Institute for Standardization of Serbia, Belgrade, Serbia, 5 p. (in Serbian).

SRPS ISO/IEC 17025:2006 (2006): General requirements for the competence of testing and calibration laboratories.- Institute for Standardization of Serbia, Belgrade, Serbia, 59 p. (in Serbian).
STEVANOVIĆ, P. (1951): Pontische Stufe im Engeren Sinne-obere Congerienschichten Serbiens und der angrenzenden Gebiete-- Serbische Akademie der Wissenschaften, Bd. CLXXXVII, No.2, 293-361 (in German).

SUTCU, E.C. \& KARAYIGIT, A.I. (2015): Mineral matter, major and trace element content of the Af̧̧in-Elbistan coals, Kahramanmaraş, Turkey.- International Journal of Coal Geology, 144, 111-129.

SWAINE, D.J. (1990): Trace Elements in Coal.- Butterworth \& Co. Ltd, London. 278 p.

SWAINE, D.J. \& GOODARZI, F. (eds.) (1995): Environmental Aspects of Trace Elements in Coal.- Kluwer Acad. Publ, The Netherlands, 312 p. doi: 10.1007/978-94015-8496-8

SYKOROVA, I., PICKEL, W., CHRISTANIS, K., WOLF, M., TAYLOR, G.H. \& FLORES, D. (2005): Classification of huminite-ICCP System 1994.- International Journal of Coal Geology, 62, 85-106.

SZTANÓ, O., SZÁFIAN, P., MAGYAR, I., HORÁNYI, A., BADA, G., HUGHES, D.W., HOYER, D.L. \& WALLIS, R.J. (2013): Aggradation and progradation controlled clinothems and deep-water sand delivery model in the Neogene Lake Pannon, Makó Trough, Pannonian Basin, SE Hungary.- Global Planetary Change, 103, 149-167.

TAYLOR, G.H., TEICHMÜLLER, M., DAVIS, A., DIESSEL, C.F.K., LITTKE, R. \& ROBERT, P. (1998): Organic Petrology.- Gebrüder Borntraeger, Berlin.

VASSILEV, S. \& VASSILEVA, C. (1998): Comparative chemical and mineral characterization of some Bulgarian coals.- Fuel Processing Technology, 55, 55-69. doi: 10.1016/S0378-3820(97)00079-9

VASSILEV, S. \& VASSILEVA, C. (2009): A new approach for the combined chemical and mineral classification of the inorganic matter in coal. 1. Chemical and mineral classification systems.- Fuel, 88, 235-245. doi: 10.1016/j.fuel.2008.09.006

VASSILEV, S.V., ESKENAZY, G.M. \& VASSILEVA, C.G. (2001): Behaviour of elements and minerals during preparation and combustion of the Pernik coal, Bulgaria.- Fuel Procesing Technology, 72, 103-129. doi: 10.1016/S0378-3820(01) 00186-2

VASSILEV, S., VASSILEVA, C., BAXTER, D. \& ANDERSEN, L K. (2009): A new approach for the combined chemical and mineral classification of the inorganic matter in coal. 2. Potential applications of the classification systems.- Fuel, 88, 246-254. doi: 10.1016/j.fuel.2008.09.005

VASSILEV, S.V., VASSILEVA, C.G., KARAYIGIT, A.I., BULUT, Y., ALASTUEY, A. \& QUEROL, X. (2005): Phase-mineral and chemical composition of composite samples from feed coals, bottom ashes and fly ashes at the Soma power station, Turkey.- International Journal of Coal Geology, 61/(1-2), 35-63. doi: 10.1016/j. coal.2004.06.004

VASSILEVA, C. \& VASSILEV, S. (2005): Behaviour of inorganic matter during heating of Bulgarian coals. 1. Lignites.- Fuel Processing Technology, 86, 1297-333.

WARD, C.R. (2002): Analysis and significance of mineral matter in coal seams.- International Journal of Coal Geology, 50, 135-168. doi: 10.1016/S0166-5162(02) $00117-9$

WARD, C.R. (2016): Analysis, origin and significance of mineral matter in coal: an updated review.- International Journal of Coal Geology, 165, 1-27. doi: 10.1016/j. coal.2016.07.014

YUDOVICH, YA.E. (1978): Geochemistry of Fossil Coals.- Nauka, Leningrad ["Science" Pub. House], 262 p. (in Russian).

YUDOVICH, YA.E. \& KETRIS, M.P. (2002): Inorganic Matter of Coals. UrO RAN. Ekaterinburg [Ural Division of the Russian Acad. Sci.], 422 p. (in Russian).

YUDOVICH, YA.E. \& KETRIS, M.P. (2005a): Arsenic in coal: a review.- International Journal of Coal Geology, 61, 141-196. doi: 10.1016/j.coal.2004.09.003

YUDOVICH, YA.E. \& KETRIS, M.P. (2005b): Toxic Trace Elements in Coal. UrO RAN, Ekaterinburg [Ural Division of the Russian Acad. Sci.], 655 p. (in Russian).

YUDOVICH, YA.E. \& KETRIS, M.P. (2006): Selenium in coal: a review.- International Journal of Coal Geology, 67, 112-126. doi: 10.1016/j.coal.2005.09.003

YUDOVICH, YA.E., KETRIS, M.P. \& MERTS, A.V. (1985): Trace Elements in Fossil Coals.- Nauka, Leningrad ["Science” Pub. House], 239 p. (in Russian).

ZHANG, Y., TIAN, J., FENG, S., YANG, F. \& LU, X. (2018): The occurrence modes and geologic origins of arsenic in coal from Santanghu Coalfield, Xinjiang.- Journal of Geochemical Exploration, 186, 225-234. doi: 10.1016/j.gexplo.2017.12.006

ŽIVOTIĆ, D., ERCEGOVAC, M. \& MILIVOJEVIĆ, J. (2005): Petrographic Composition and Genesis of Coal From the Kovin Deposit- $14^{\text {th }}$ Congress of Geologists of Serbia and Montenegro, 18-20 October, Novi Sad, Book of abstracts, p. 322. (ISBN 86-86053-00-9).

ŽIVOTIĆ, D., SIMIĆ, V., GRŽETIĆ, I. \& LORENZ, H. (2015): Potentially toxic trace elements in some Serbian brown coals. - Reports of the Serbian Geological Society (for the year 2015), 1-14. Serbian Geological Society, Belgrade, ISSN 03729966.

ŽIVOTIĆ, D., WEHNER, H., OSTERTAG-HENNING, C., ERCEGOVAC, M., SCHEEDER, G., JOVANČIĆEVIĆ, B., CVETKOVIĆ, O., GRŽETIĆ, I., MILIVOJEVIĆ, J., STOJANOVIĆ, K. \& ŠAJNOVIĆ, A. (2007): The organic geochemical, petrographical and palynological composition of coal from the Kovin deposit (Serbia).Abstract Book $23^{\text {rd }}$ International meeting on organic geochemistry. Torquay, England, 565-566. (ISBN 978-0-9556551-0-4). 


\section{SUPPLEMENTARY MATERIAL}

Table S-I. List of samples with depth, field, coal seam and lithology of the Kovin lignite (after MITROVIĆ et al., 2016, 2017).

\begin{tabular}{|c|c|c|c|c|c|c|}
\hline No & Borehole ID & Field & Coal Seam & Sample ID & Depth & Lithology \\
\hline 1 & KB-79 & B & $\|$ & $2 / 79$ & $35.35-36.00$ & MC \\
\hline 2 & & & $\|$ & $3 / 79$ & $36.80-37.60$ & MXC \\
\hline 3 & & & $\|$ & $4 / 79$ & $38.00-38.20$ & $X C$ \\
\hline 4 & & & $\|$ & $5 / 79$ & $38.50-39.00$ & MXC \\
\hline 5 & & & $\|$ & $6 / 79$ & $39.00-39.10$ & MMiC \\
\hline 6 & & & $\|$ & $8 / 79$ & $40.15-40.65$ & MXC \\
\hline 7 & & & III & $11 / 79$ & $67.90-69.30$ & $\mathrm{MMiC}$ \\
\hline 8 & & & III & $14 / 79$ & $114.10-114.25$ & $X C$ \\
\hline 9 & & & III & $15 / 79$ & $114.45-114.75$ & MXC \\
\hline 10 & & & III & $16 / 79$ & $114.75-114.85$ & $x C$ \\
\hline 11 & & & III & $17 / 79$ & $115.00-115.30$ & $\mathrm{MMiC}$ \\
\hline 12 & & & III & $18 / 79$ & $115.30-115.45$ & MXC \\
\hline 13 & & & III & $19 / 79$ & $115.45-116.00$ & MMiC \\
\hline 14 & & & III & $20 / 79$ & $116.05-116.30$ & MMiC \\
\hline 15 & & & III & $21 / 79$ & $116.30-116.60$ & MiC \\
\hline 16 & & & & $24 / 79$ & $247.65-248.05$ & MXC \\
\hline 17 & KB-91 & B & 1 & $26 / 91$ & $22.50-24.25$ & MC \\
\hline 18 & & & 1 & $27 / 91$ & $24.60-25.00$ & $x C$ \\
\hline 19 & & & 1 & $28 / 91$ & $25.50-25.75$ & MC \\
\hline 20 & & & 1 & $29 / 91$ & $25.75-26.35$ & $x C$ \\
\hline 21 & & & 1 & $30 / 91$ & $26.35-27.65$ & MC \\
\hline 22 & & & 1 & $31 / 91$ & $27.65-28.15$ & MMiC \\
\hline 23 & & & $\|$ & $33 / 91$ & $45.00-45.60$ & MXC \\
\hline 24 & & & $\|$ & $34 / 91$ & $45.60-46.05$ & $x C$ \\
\hline 25 & & & ॥ & $36 / 91$ & $47.05-48.35$ & MMiC \\
\hline 26 & & & ॥ & $37 / 91$ & $48.60-49.30$ & MXC \\
\hline 27 & & & ॥ & $38 / 91$ & $49.30-49.50$ & $x C$ \\
\hline 28 & & & ॥ & $39 / 91$ & $50.60-50.90$ & MMiC \\
\hline 29 & & & $\|$ & $40 / 91$ & $51.60-52.85$ & MC \\
\hline 30 & GD-601 & A & I (la) & $42 / 601$ & $42.65-43.10$ & $x C$ \\
\hline 31 & & & I (la) & $43 / 601$ & $43.10-43.50$ & MC \\
\hline 32 & & & I (lb) & $44 / 601$ & $73.70-75.50$ & MXC \\
\hline 33 & & & I (lb) & $45 / 601$ & $75.50-76.00$ & MXC \\
\hline 34 & & & I (lb) & $46 / 601$ & $76.00-76.40$ & MC \\
\hline 35 & & & $\|$ & $47 / 601$ & $95.30-95.80$ & MXC \\
\hline 36 & & & ॥ & $48 / 601$ & $96.40-97.00$ & MMiC \\
\hline 37 & & & $\|$ & $49 / 601$ & $97.00-97.50$ & MC \\
\hline 38 & GD-603 & A & I (la) & $50 / 603$ & $39.00-39.55$ & $x C$ \\
\hline 39 & & & I (lb) & $51 / 603$ & $65.15-65.35$ & MC \\
\hline 40 & & & I (lb) & $52 / 603$ & $65.60-65.70$ & $x C$ \\
\hline 41 & & & I (lb) & $53 / 603$ & $65.70-66.65$ & MXC \\
\hline 42 & & & ॥ & $54 / 603$ & $88.00-88.12$ & $x C$ \\
\hline 43 & & & ॥ & $55 / 603$ & $88.40-88.60$ & MXC \\
\hline 44 & & & $\|$ & $56 / 603$ & $88.60-88.80$ & MMiC \\
\hline
\end{tabular}

MC - Stratified matrix coal (weakly gelified); XC - Xylite-rich coal; MXC - Mixture of matrix and xylite-rich coal and Mixture of xylite-rich and matrix coal; MMiC - Mixture of matrix and mineral-rich coal; MiC - Mineral-rich coal (TAYLOR et al., 1998). 


\begin{tabular}{|c|c|c|c|c|c|c|c|c|}
\hline \multirow{2}{*}{ Sample ID } & \multirow{2}{*}{ Coal Seam } & \multicolumn{7}{|c|}{ Proximate analyses } \\
\hline & & $\mathrm{W}^{\mathrm{ar}}$ (wt.\%) & $W^{a n}$ (wt.\%) & $A^{d b}(w t . \%)$ & $\mathrm{S}^{\mathrm{db}}(w \mathrm{wt} . \%)$ & $\mathrm{V}^{\mathrm{db}}(\mathrm{wt} . \%)$ & $\mathrm{Q}_{\mathrm{g}}{ }^{\mathrm{daf}}(\mathrm{MJ} / \mathrm{kg})$ & $\mathrm{Q}_{\mathrm{n}}{ }^{\text {daf }}(\mathrm{MJ} / \mathrm{kg})$ \\
\hline $2 / 79$ & II & 50.68 & 6.52 & 19.00 & 1.88 & 46.29 & 25.9 & 24.8 \\
\hline $3 / 79$ & II & 30.36 & 5.99 & 59.84 & 1.67 & 26.57 & 18.9 & 17.8 \\
\hline $4 / 79$ & $\|$ & 50.07 & 3.80 & 20.63 & 2.87 & 42.29 & 26.1 & 25.1 \\
\hline $5 / 79$ & $\|$ & 47.11 & 2.95 & 28.02 & 0.78 & 38.98 & 24.8 & 23.7 \\
\hline $6 / 79$ & $\|$ & 27.81 & 5.60 & 63.83 & 0.51 & 23.13 & 17.9 & 17.0 \\
\hline $8 / 79$ & $\|$ & 48.08 & 5.38 & 25.70 & 3.34 & 42.85 & 25.1 & 23.9 \\
\hline $11 / 79$ & III & 13.78 & 4.10 & 78.20 & 0.21 & 11.38 & 15.7 & 14.3 \\
\hline $14 / 79$ & III & 52.89 & 4.78 & 12.62 & 1.53 & 46.71 & 26.3 & 25.3 \\
\hline $15 / 79$ & III & 49.31 & 4.23 & 22.62 & 1.24 & 41.47 & 25.9 & 24.9 \\
\hline $16 / 79$ & III & 54.13 & 10.38 & 8.66 & 1.33 & 43.11 & 25.6 & 24.6 \\
\hline $17 / 79$ & III & 32.55 & 7.49 & 56.29 & 0.82 & 23.45 & 23.5 & 22.5 \\
\hline $18 / 79$ & III & 47.28 & 11.09 & 27.62 & 1.45 & 37.81 & 24.2 & 23.3 \\
\hline $19 / 79$ & III & 48.15 & 12.73 & 25.51 & 1.70 & 41.15 & 25.8 & 24.8 \\
\hline 20/79 & III & 31.34 & 4.48 & 58.27 & 2.13 & 23.18 & 21.3 & 20.3 \\
\hline $21 / 79$ & III & 11.79 & 1.90 & 65.96 & 0.56 & 9.67 & 18.7 & 18.2 \\
\hline $24 / 79$ & & 47.84 & 11.08 & 26.26 & 1.83 & 39.13 & 26.3 & 25.4 \\
\hline $26 / 91$ & I & 40.08 & 6.78 & 42.91 & 1.80 & 35.44 & 23.3 & 22.1 \\
\hline $27 / 91$ & I & 51.08 & 11.08 & 17.90 & 1.98 & 46.97 & 25.1 & 24.1 \\
\hline 28/91 & I & 35.75 & 9.75 & 50.85 & 1.73 & 27.95 & 23.0 & 21.7 \\
\hline 29/91 & I & 50.28 & 7.85 & 20.08 & 1.41 & 47.48 & 25.3 & 24.2 \\
\hline $30 / 91$ & 1 & 41.18 & 9.82 & 40.76 & 3.33 & 33.81 & 22.8 & 22.1 \\
\hline $31 / 91$ & I & 34.76 & 6.75 & 52.56 & 4.40 & 29.88 & 21.0 & 20.1 \\
\hline $33 / 91$ & $\|$ & 43.54 & 11.70 & 35.95 & 1.46 & 37.97 & 24.3 & 23.3 \\
\hline $34 / 91$ & II & 49.65 & 4.26 & 21.74 & 1.65 & 45.34 & 25.9 & 24.8 \\
\hline $36 / 91$ & II & 32.66 & 4.02 & 56.11 & 1.35 & 28.08 & 21.2 & 19.9 \\
\hline $37 / 91$ & II & 51.59 & 11.60 & 16.47 & 3.12 & 48.33 & 25.6 & 24.6 \\
\hline $38 / 91$ & II & 51.62 & 7.16 & 16.38 & 0.80 & 46.09 & 25.5 & 24.4 \\
\hline $39 / 91$ & II & 43.01 & 10.05 & 37.05 & 1.00 & 36.69 & 24.4 & 23.3 \\
\hline $40 / 91$ & II & 42.59 & 6.76 & 37.92 & 0.92 & 35.49 & 23.9 & 22.6 \\
\hline $42 / 601$ & I (la) & 45.65 & 9.03 & 31.36 & 2.28 & 40.78 & 24.2 & 23.2 \\
\hline $43 / 601$ & I (la) & 44.35 & 10.02 & 34.23 & 2.85 & 37.73 & 24.3 & 23.3 \\
\hline $44 / 601$ & I (lb) & 47.21 & 12.02 & 27.78 & 3.96 & 45.02 & 25.1 & 24.2 \\
\hline $45 / 601$ & I (lb) & 43.79 & 6.66 & 35.43 & 1.86 & 38.44 & 23.8 & 22.7 \\
\hline $46 / 601$ & I (lb) & 48.60 & 12.38 & 24.40 & 1.69 & 42.75 & 23.4 & 22.5 \\
\hline $47 / 601$ & II & 49.92 & 4.77 & 21.03 & 2.26 & 44.50 & 25.8 & 24.7 \\
\hline $48 / 601$ & $\|$ & 31.66 & 4.91 & 57.75 & 2.94 & 25.88 & 20.2 & 19.1 \\
\hline $49 / 601$ & II & 44.40 & 4.77 & 34.11 & 0.97 & 38.30 & 24.2 & 23.1 \\
\hline $50 / 603$ & I (la) & 50.79 & 5.84 & 18.69 & 1.67 & 45.47 & 26.0 & 24.9 \\
\hline $51 / 603$ & I (lb) & 51.45 & 9.89 & 16.86 & 0.82 & 46.88 & 28.3 & 27.2 \\
\hline $52 / 603$ & I (lb) & 52.90 & 15.24 & 12.58 & 1.68 & 44.02 & 26.4 & 25.5 \\
\hline $53 / 603$ & I (lb) & 34.57 & 7.24 & 52.90 & 1.63 & 29.26 & 22.3 & 21.1 \\
\hline $54 / 603$ & II & 52.48 & 10.68 & 13.85 & 1.67 & 50.26 & 27.8 & 26.7 \\
\hline $55 / 603$ & II & 23.67 & 4.14 & 54.98 & 1.07 & 19.29 & 21.7 & 20.9 \\
\hline $56 / 603$ & II & 14.42 & 8.53 & 68.60 & 0.22 & 12.10 & 16.9 & 16.3 \\
\hline
\end{tabular}

$W^{\mathrm{ar}}$ - moisture content, as received basis, \%; Wan - analytical moisture content, \%; $\mathrm{A}^{\mathrm{db}}$ - ash content, dry basis, \%; $\mathrm{S}^{\mathrm{db}}$ - total sulphur content, dry basis wt.\%; $\mathrm{V}^{\mathrm{db}}$ - volatile matter, dry basis wt.\%; $\mathrm{Q}_{\mathrm{g}}^{\text {daf }}$ - gross calorific value, dry, ash-free basis, $\mathrm{MJ} / \mathrm{kg} ; \mathrm{Q}_{\mathrm{n}}^{\text {daf }}$ - net calorific value, dry, ash-free basis, $\mathrm{MJ} / \mathrm{kg} ; \mathrm{C}^{\text {daf }}$ - carbon content, dry, ash-free basis, \%; $\mathrm{H}^{\text {daf }}$ - hidrogen content, dry, ash-free basis, \%; $\mathrm{N}^{\text {daf }}$ - nitrogen content, dry, ash-free basis; $\mathrm{O}^{\text {daf }}$ - oxigen content, dry, ash-free basis. 
Table S-II. Continued.

\begin{tabular}{|c|c|c|c|c|}
\hline \multirow{2}{*}{ Sample ID } & \multicolumn{4}{|c|}{ Ultimate analyses } \\
\hline & $C^{\text {daf }}$ (wt.\%) & $\mathrm{H}^{\text {daf }}$ (wt.\%) & $\mathrm{N}^{\text {daf }}$ (wt.\%) & $\mathrm{O}^{\text {daf }}$ (wt.\%) \\
\hline $2 / 79$ & 66.75 & 5.25 & 1.20 & 24.48 \\
\hline $3 / 79$ & 59.71 & 5.18 & 1.39 & 29.56 \\
\hline $4 / 79$ & 66.01 & 4.51 & 1.01 & 24.85 \\
\hline $5 / 79$ & 65.34 & 5.18 & 1.21 & 27.19 \\
\hline $6 / 79$ & 52.25 & 4.56 & 1.35 & 40.42 \\
\hline $8 / 79$ & 64.35 & 5.20 & 0.81 & 25.15 \\
\hline $11 / 79$ & 57.43 & 6.65 & 1.51 & 33.12 \\
\hline $14 / 79$ & 66.33 & 4.82 & 1.05 & 26.05 \\
\hline $15 / 79$ & 65.90 & 5.05 & 1.09 & 26.37 \\
\hline $16 / 79$ & 66.67 & 3.92 & 1.08 & 26.88 \\
\hline $17 / 79$ & 68.59 & 4.37 & 1.21 & 23.95 \\
\hline $18 / 79$ & 68.68 & 4.23 & 1.22 & 23.88 \\
\hline $19 / 79$ & 70.45 & 4.31 & 1.17 & 21.79 \\
\hline $20 / 79$ & 65.37 & 4.96 & 1.32 & 23.25 \\
\hline $21 / 79$ & 55.23 & 2.61 & 0.79 & 41.09 \\
\hline $24 / 79$ & 63.36 & 4.03 & 0.68 & 29.45 \\
\hline $26 / 91$ & 61.88 & 5.27 & 0.79 & 28.90 \\
\hline $27 / 91$ & 66.83 & 4.35 & 1.11 & 25.30 \\
\hline $28 / 91$ & 61.32 & 6.53 & 1.89 & 26.73 \\
\hline 29/91 & 63.56 & 4.79 & 0.93 & 28.96 \\
\hline $30 / 91$ & 56.48 & 2.95 & 1.22 & 33.73 \\
\hline $31 / 91$ & 62.23 & 4.28 & 1.37 & 22.85 \\
\hline $33 / 91$ & 66.93 & 4.34 & 1.22 & 25.23 \\
\hline $34 / 91$ & 64.13 & 5.12 & 0.97 & 27.66 \\
\hline $36 / 91$ & 63.41 & 6.31 & 0.89 & 26.31 \\
\hline $37 / 91$ & 70.09 & 4.44 & 1.04 & 20.77 \\
\hline $38 / 91$ & 66.50 & 4.76 & 1.08 & 26.70 \\
\hline $39 / 91$ & 64.62 & 4.65 & 0.97 & 28.16 \\
\hline $40 / 91$ & 74.02 & 6.11 & 1.34 & 17.06 \\
\hline $42 / 601$ & 64.58 & 4.66 & 1.02 & 26.41 \\
\hline $43 / 601$ & 65.50 & 4.56 & 1.31 & 24.30 \\
\hline $44 / 601$ & 66.81 & 4.03 & 1.15 & 22.53 \\
\hline $45 / 601$ & 64.64 & 4.99 & 1.10 & 26.39 \\
\hline $46 / 601$ & 67.06 & 4.17 & 1.22 & 25.32 \\
\hline $47 / 601$ & 64.80 & 5.17 & 0.99 & 26.19 \\
\hline $48 / 601$ & 58.30 & 5.33 & 1.11 & 28.31 \\
\hline $49 / 601$ & 64.61 & 5.43 & 0.90 & 27.59 \\
\hline $50 / 603$ & 66.12 & 5.02 & 0.96 & 25.86 \\
\hline $51 / 603$ & 73.24 & 4.78 & 0.90 & 20.09 \\
\hline $52 / 603$ & 69.55 & 3.80 & 1.43 & 23.30 \\
\hline $53 / 603$ & 61.97 & 5.41 & 1.38 & 27.77 \\
\hline $54 / 603$ & 69.47 & 5.01 & 0.87 & 22.70 \\
\hline $55 / 603$ & 62.08 & 3.84 & 0.64 & 29.87 \\
\hline $56 / 603$ & 60.16 & 2.96 & 0.89 & 35.71 \\
\hline
\end{tabular}

Table S-III. Quantitative mineralogical composition of the Kovine lignite ashes $\left(450^{\circ} \mathrm{C}\right)$ by XRPD analysis (wt.\%; on organic matter-free basis) of individual samples.

\begin{tabular}{|c|c|c|c|c|c|c|c|}
\hline $\begin{array}{l}\text { Sample } \\
\text { ID }\end{array}$ & $\begin{array}{l}\text { Coal } \\
\text { Seam }\end{array}$ & $\begin{array}{r}\text { Illite/ } \\
\text { smectite }\end{array}$ & Quartz & $\begin{array}{r}\text { Anhy- } \\
\text { drite }\end{array}$ & $\begin{array}{l}\text { Plagio- } \\
\text { clase }\end{array}$ & $\begin{array}{r}\text { Hema- } \\
\text { tite }\end{array}$ & Calcite \\
\hline $2 / 79$ & $\|$ & 23.0 & 10.5 & 47.0 & 2.6 & 8.4 & 8.5 \\
\hline $3 / 79$ & II & 45.3 & 27.9 & 14.8 & 7.1 & 3.1 & 1.8 \\
\hline $4 / 79$ & II & 21.5 & 13.3 & 42.6 & 4.0 & 18.6 & 0 \\
\hline $5 / 79$ & II & 50.3 & 19.1 & 9.6 & 4.5 & 0.3 & 16.3 \\
\hline $6 / 79$ & II & 73.6 & 19.9 & 0 & 2.5 & 0 & 4.0 \\
\hline $8 / 79$ & II & 33.0 & 11.0 & 36.1 & 0.5 & 18.2 & 1.2 \\
\hline $11 / 79$ & III & 20.4 & 62.4 & 0.6 & 15.4 & 0.1 & 1.2 \\
\hline $14 / 79$ & III & 17.6 & 15.8 & 42.8 & 6.6 & 5.7 & 11.4 \\
\hline $15 / 79$ & III & 18.4 & 45.4 & 15.9 & 13.1 & 4.5 & 2.8 \\
\hline $16 / 79$ & III & 11.7 & 6.0 & 47.7 & 1.7 & 4.6 & 28.4 \\
\hline $17 / 79$ & III & 13.9 & 61.5 & 4.7 & 17.2 & 2.5 & 0.4 \\
\hline $18 / 79$ & III & 30.6 & 37.1 & 16.8 & 11.2 & 1.4 & 3.0 \\
\hline $19 / 79$ & III & 30.8 & 25.5 & 29.7 & 6.3 & 5.4 & 2.3 \\
\hline $20 / 79$ & III & 12.7 & 67.2 & 5.6 & 12.9 & 1.6 & 0 \\
\hline $21 / 79$ & III & 15.1 & 69.3 & 1.6 & 13.3 & 0.6 & 0.1 \\
\hline $24 / 79$ & & 14.8 & 50.7 & 13.5 & 17.4 & 3.6 & 0 \\
\hline $26 / 91$ & 1 & 42.3 & 29.4 & 14.8 & 4.7 & 6.0 & 2.8 \\
\hline $27 / 91$ & 1 & 22.3 & 10.1 & 45.6 & 2.5 & 15.2 & 4.3 \\
\hline 28/91 & 1 & n.a & n.a & n.a & n.a & n.a & n.a \\
\hline 29/91 & 1 & 35.3 & 19.2 & 30.9 & 4.2 & 7.9 & 2.6 \\
\hline $30 / 91$ & 1 & 28.9 & 28.6 & 28.4 & 3.4 & 9.8 & 0.9 \\
\hline $31 / 91$ & 1 & n.a & n.a & n.a & n.a & n.a & n.a \\
\hline $33 / 91$ & II & 47.7 & 28.3 & 12.4 & 4.3 & 3.5 & 3.9 \\
\hline $34 / 91$ & II & 47.8 & 15.9 & 24.6 & 2.6 & 6.1 & 3.1 \\
\hline $36 / 91$ & II & 53.8 & 27.5 & 9.3 & 4.1 & 3.4 & 1.9 \\
\hline $37 / 91$ & II & 19.9 & 8.6 & 50.7 & 0.8 & 19.6 & 0.4 \\
\hline $38 / 91$ & II & 25.0 & 30.4 & 12.1 & 12.0 & 0.3 & 20.3 \\
\hline $39 / 91$ & II & 40.2 & 37.2 & 9.4 & 8.3 & 1.7 & 3.3 \\
\hline $40 / 91$ & II & 63.2 & 15.1 & 9.9 & 8.7 & 0 & 3.3 \\
\hline $42 / 601$ & I (la) & 18.3 & 37.8 & 24.4 & 7.9 & 7.0 & 4.6 \\
\hline $43 / 601$ & I (la) & 13.6 & 51.7 & 18.9 & 8.9 & 7.0 & 0 \\
\hline $44 / 601$ & I (lb) & 23.9 & 12.0 & 45.0 & 2.0 & 17.1 & 0.01 \\
\hline $45 / 601$ & I (lb) & 38.8 & 20.2 & 24.9 & 5.5 & 8.1 & 2.6 \\
\hline $46 / 601$ & I (lb) & 17.5 & 52.6 & 13.1 & 11.0 & 4.7 & 1.1 \\
\hline $47 / 601$ & II & 34.8 & 14.6 & 34.2 & 3.4 & 11.3 & 1.7 \\
\hline $48 / 601$ & II & 43.4 & 23.6 & 15.0 & 6.9 & 9.1 & 1.9 \\
\hline $49 / 601$ & II & 43.5 & 37.6 & 10.3 & 6.6 & 0.5 & 1.5 \\
\hline $50 / 603$ & I (la) & 20.0 & 24.5 & 38.6 & 4.7 & 9.8 & 2.4 \\
\hline $51 / 603$ & I (lb) & 25.1 & 37.4 & 16.7 & 5.9 & 0 & 14.9 \\
\hline $52 / 603$ & I (lb) & 12.1 & 4.0 & 52.3 & 0.7 & 5.7 & 25.3 \\
\hline $53 / 603$ & I (lb) & 46.7 & 22.6 & 17.4 & 8.8 & 4.4 & 0.3 \\
\hline $54 / 603$ & II & 14.8 & 14.3 & 54.6 & 3.9 & 9.5 & 2.9 \\
\hline $55 / 603$ & II & 22.4 & 57.2 & 6.2 & 10.0 & 1.7 & 2.5 \\
\hline $56 / 603$ & II & 36.5 & 45.1 & 3.2 & 11.9 & 0.8 & 2.6 \\
\hline
\end{tabular}

n.a - Not analysed. 


\begin{tabular}{|c|c|c|c|c|c|c|c|c|c|c|c|}
\hline Sample ID & Coal Seam & $\mathrm{Si}$ & $\mathrm{Al}$ & $\mathrm{Si} / \mathrm{Al}$ & $\mathrm{Fe}$ & $\mathrm{Ti}$ & $\mathrm{Ca}$ & $\mathrm{Mg}$ & $\mathrm{Na}$ & K & $\mathrm{Mn}$ \\
\hline $2 / 79$ & II & 2.55 & 1.19 & 2.15 & 1.51 & 0.04 & 2.15 & 0.42 & 0.08 & 0.09 & 0.038 \\
\hline $3 / 79$ & II & 12.68 & 5.72 & 2.22 & 3.45 & 0.25 & 1.12 & 0.41 & 0.13 & 0.18 & 0.013 \\
\hline $4 / 79$ & $\|$ & 3.10 & 1.53 & 2.03 & 2.80 & 0.08 & 1.33 & 0.35 & 0.05 & 0.09 & 0.011 \\
\hline $5 / 79$ & $\|$ & 0.40 & 0.20 & 2.03 & 0.36 & 0.01 & 0.17 & 0.04 & 0.01 & 0.01 & 0.001 \\
\hline $6 / 79$ & ॥ & 13.46 & 4.49 & 3.00 & 2.51 & 0.31 & 0.95 & 0.18 & 0.09 & 0.19 & 0.010 \\
\hline $8 / 79$ & II & 4.36 & 2.72 & 1.61 & 3.25 & 0.09 & 1.22 & 0.38 & 0.04 & 0.15 & 0.008 \\
\hline $11 / 79$ & III & 21.84 & 4.37 & 5.00 & 3.70 & 0.25 & 1.05 & 0.44 & 0.49 & 0.55 & 0.034 \\
\hline $14 / 79$ & III & 1.50 & 0.66 & 2.26 & 1.00 & 0.03 & 1.92 & 0.36 & 0.13 & 0.04 & 0.008 \\
\hline $15 / 79$ & III & 4.48 & 1.79 & 2.50 & 1.02 & 0.09 & 1.55 & 0.37 & 0.18 & 0.16 & 0.009 \\
\hline $16 / 79$ & III & 0.34 & 0.26 & 1.28 & 0.80 & 0.01 & 2.10 & 0.33 & 0.11 & 0.02 & 0.011 \\
\hline $17 / 79$ & III & 14.53 & 3.08 & 4.72 & 1.79 & 0.20 & 1.83 & 0.48 & 0.61 & 0.52 & 0.021 \\
\hline $18 / 79$ & III & 6.46 & 2.28 & 2.84 & 1.59 & 0.10 & 1.99 & 0.42 & 0.25 & 0.24 & 0.014 \\
\hline $19 / 79$ & III & 4.83 & 2.56 & 1.89 & 1.31 & 0.12 & 2.04 & 0.44 & 0.16 & 0.12 & 0.009 \\
\hline $20 / 79$ & III & 13.35 & 2.84 & 4.71 & 2.95 & 0.15 & 1.56 & 0.41 & 0.50 & 0.38 & 0.015 \\
\hline $21 / 79$ & III & 19.79 & 3.70 & 5.34 & 3.00 & 0.29 & 0.98 & 0.36 & 0.64 & 0.46 & 0.016 \\
\hline $24 / 79$ & & 6.85 & 1.57 & 4.36 & 1.73 & 0.10 & 0.94 & 0.27 & 0.45 & 0.25 & 0.013 \\
\hline $26 / 91$ & 1 & 9.01 & 4.68 & 1.93 & 2.61 & 0.16 & 1.14 & 0.36 & 0.09 & 0.13 & 0.015 \\
\hline $27 / 91$ & 1 & 2.30 & 1.38 & 1.67 & 1.99 & 0.05 & 1.88 & 0.32 & 0.04 & 0.05 & 0.016 \\
\hline $28 / 91$ & 1 & 11.87 & 3.46 & 3.43 & 2.48 & 0.16 & 1.76 & 0.51 & 0.29 & 0.33 & 0.030 \\
\hline $29 / 91$ & I & 3.84 & 2.18 & 1.76 & 1.49 & 0.08 & 1.38 & 0.30 & 0.05 & 0.08 & 0.014 \\
\hline $30 / 91$ & I & 8.19 & 4.06 & 2.02 & 3.71 & 0.15 & 1.64 & 0.42 & 0.10 & 0.16 & 0.018 \\
\hline $31 / 91$ & 1 & 9.77 & 1.58 & 6.17 & 9.01 & 0.09 & 1.44 & 0.28 & 0.33 & 0.26 & 0.154 \\
\hline $33 / 91$ & II & 7.60 & 3.65 & 2.08 & 2.60 & 0.13 & 1.68 & 0.59 & 0.06 & 0.25 & 0.021 \\
\hline $34 / 91$ & II & 3.92 & 1.80 & 2.18 & 1.83 & 0.06 & 1.56 & 0.42 & 0.05 & 0.17 & 0.016 \\
\hline $36 / 91$ & II & 12.75 & 5.02 & 2.54 & 3.52 & 0.24 & 1.00 & 0.34 & 0.09 & 0.14 & 0.014 \\
\hline $37 / 91$ & II & 2.32 & 1.44 & 1.61 & 2.43 & 0.05 & 1.55 & 0.35 & 0.04 & 0.07 & 0.015 \\
\hline $38 / 91$ & II & 2.68 & 1.34 & 2.00 & 0.78 & 0.04 & 1.88 & 0.41 & 0.08 & 0.09 & 0.019 \\
\hline $39 / 91$ & II & 8.80 & 3.76 & 2.34 & 1.84 & 0.15 & 1.33 & 0.47 & 0.15 & 0.26 & 0.014 \\
\hline $40 / 91$ & II & 8.38 & 3.99 & 2.10 & 1.89 & 0.14 & 1.32 & 0.49 & 0.09 & 0.25 & 0.013 \\
\hline $42 / 601$ & I (la) & 6.08 & 2.26 & 2.69 & 2.60 & 0.14 & 1.96 & 0.41 & 0.15 & 0.17 & 0.017 \\
\hline $43 / 601$ & I (la) & 7.60 & 2.35 & 3.23 & 2.73 & 0.16 & 1.96 & 0.54 & 0.18 & 0.15 & 0.018 \\
\hline $44 / 601$ & I (lb) & 4.86 & 2.52 & 1.93 & 3.55 & 0.09 & 2.14 & 0.54 & 0.09 & 0.14 & 0.018 \\
\hline $45 / 601$ & I (lb) & 6.68 & 2.91 & 2.30 & 2.67 & 0.11 & 3.19 & 0.58 & 0.11 & 0.12 & 0.027 \\
\hline $46 / 601$ & I (lb) & 7.83 & 2.08 & 3.76 & 2.46 & 0.09 & 2.05 & 0.45 & 0.17 & 0.17 & 0.031 \\
\hline $47 / 601$ & II & 3.88 & 1.89 & 2.06 & 2.39 & 0.06 & 1.53 & 0.43 & 0.08 & 0.12 & 0.014 \\
\hline $48 / 601$ & II & 12.00 & 3.87 & 3.10 & 5.03 & 0.22 & 1.18 & 0.29 & 0.11 & 0.20 & 0.017 \\
\hline $49 / 601$ & ॥ & 7.43 & 3.17 & 2.35 & 1.75 & 0.11 & 1.52 & 0.56 & 0.14 & 0.31 & 0.014 \\
\hline $50 / 603$ & I (la) & 3.07 & 1.17 & 2.61 & 1.86 & 0.05 & 1.91 & 0.39 & 0.10 & 0.09 & 0.015 \\
\hline $51 / 603$ & I (lb) & 2.32 & 0.95 & 2.44 & 0.59 & 0.04 & 1.54 & 0.25 & 0.12 & 0.08 & 0.017 \\
\hline $52 / 603$ & I (lb) & 0.88 & 0.52 & 1.72 & 1.48 & 0.02 & 2.68 & 0.42 & 0.15 & 0.04 & 0.016 \\
\hline $53 / 603$ & I (lb) & 11.69 & 5.15 & 2.27 & 4.00 & 0.18 & 1.44 & 0.67 & 0.12 & 0.44 & 0.014 \\
\hline $54 / 603$ & II & 1.97 & 0.88 & 2.24 & 1.30 & 0.04 & 1.57 & 0.23 & 0.09 & 0.06 & 0.016 \\
\hline $55 / 603$ & II & 16.84 & 5.07 & 3.33 & 2.29 & 0.21 & 1.73 & 0.50 & 0.36 & 0.31 & 0.026 \\
\hline $56 / 603$ & II & 17.33 & 3.38 & 5.12 & 3.73 & 0.32 & 1.06 & 0.26 & 0.28 & 0.20 & 0.019 \\
\hline
\end{tabular}


Table S-IV. Continued.

\begin{tabular}{|c|c|c|c|c|c|c|c|c|c|c|}
\hline Sample ID & Coal Seam & $\mathrm{Rb}$ & $\mathrm{Sb}$ & Sc & $\mathrm{Se}$ & $\mathrm{Sr}$ & Th & $\mathrm{TI}$ & V & $\mathrm{Zn}$ \\
\hline $2 / 79$ & $\|$ & 7.0 & $<0.5$ & 2.8 & 1.7 & 116.7 & 0.7 & $<0.5$ & 31.0 & 38.0 \\
\hline $3 / 79$ & $\|$ & 4.2 & $<0.5$ & 14.5 & 3.0 & 69.1 & 2.1 & $<0.5$ & 110.8 & 66.0 \\
\hline $4 / 79$ & $\|$ & 6.2 & $<0.5$ & 5.0 & 2.3 & 79.8 & 1.0 & $<0.5$ & 49.8 & 31.0 \\
\hline $5 / 79$ & $\|$ & 0.8 & $<0.5$ & 0.6 & 0.3 & 10.2 & 0.1 & $<0.5$ & 6.4 & 4.0 \\
\hline $6 / 79$ & II & $<0.5$ & $<0.5$ & 15.1 & 2.5 & 58.0 & 0.9 & $<0.5$ & 89.4 & 59.4 \\
\hline $8 / 79$ & $\|$ & 15.7 & $<0.5$ & 8.1 & 2.0 & 73.9 & 1.9 & $<0.5$ & 78.7 & 47.5 \\
\hline $11 / 79$ & III & 14.2 & $<0.5$ & 8.1 & 1.9 & 120.7 & 2.8 & $<0.5$ & 49.7 & 62.5 \\
\hline $14 / 79$ & III & 0.8 & $<0.5$ & 3.2 & 1.2 & 201.7 & $<0.1$ & $<0.5$ & 16.3 & 4.3 \\
\hline $15 / 79$ & III & 11.7 & $<0.5$ & 4.7 & 1.9 & 183.9 & 1.4 & $<0.5$ & 34.0 & 16.5 \\
\hline $16 / 79$ & III & $<0.5$ & $<0.5$ & 0.6 & 0.9 & 210.3 & $<0.1$ & $<0.5$ & 3.3 & 9.1 \\
\hline $17 / 79$ & III & 36.3 & $<0.5$ & 5.1 & 3.6 & 204.4 & 2.5 & $<0.5$ & 30.9 & 35.6 \\
\hline $18 / 79$ & III & 18.0 & $<0.5$ & 5.0 & 1.8 & 175.7 & 1.9 & $<0.5$ & 35.4 & 27.2 \\
\hline $19 / 79$ & III & 9.3 & $<0.5$ & 6.2 & 4.3 & 218.9 & 1.9 & $<0.5$ & 54.5 & 39.2 \\
\hline $20 / 79$ & III & 24.9 & $<0.5$ & 4.7 & 2.6 & 186.7 & 1.8 & $<0.5$ & 31.5 & 43.6 \\
\hline $21 / 79$ & III & 10.9 & $<0.5$ & 7.1 & 3.5 & 155.3 & 2.9 & $<0.5$ & 43.0 & 43.0 \\
\hline $24 / 79$ & & 14.9 & $<0.5$ & 3.0 & 1.4 & 221.6 & 1.1 & $<0.5$ & 29.6 & 25.6 \\
\hline $26 / 91$ & 1 & 3.0 & $<0.5$ & 8.7 & 1.9 & 46.0 & 1.2 & $<0.5$ & 47.6 & 49.6 \\
\hline $27 / 91$ & 1 & 2.4 & $<0.5$ & 2.8 & 1.5 & 65.9 & 0.1 & $<0.5$ & 25.4 & 15.4 \\
\hline $28 / 91$ & 1 & 21.1 & $<0.5$ & 6.7 & 2.4 & 113.8 & 2.5 & $<0.5$ & 59.0 & 31.1 \\
\hline $29 / 91$ & 1 & 5.2 & $<0.5$ & 4.0 & 1.7 & 53.7 & 0.7 & $<0.5$ & 33.1 & 16.6 \\
\hline $30 / 91$ & 1 & 7.6 & $<0.5$ & 8.3 & 4.4 & 68.3 & 2.4 & $<0.5$ & 48.1 & 82.6 \\
\hline $31 / 91$ & 1 & 18.0 & $<0.5$ & 5.8 & 9.0 & 77.1 & 0.6 & $<0.5$ & 54.0 & 56.1 \\
\hline $33 / 91$ & $\|$ & 15.7 & $<0.5$ & 8.2 & 2.7 & 94.8 & 2.6 & $<0.5$ & 61.1 & 44.4 \\
\hline $34 / 91$ & $\|$ & 18.8 & $<0.5$ & 4.5 & 1.6 & 81.5 & 1.7 & $<0.5$ & 38.1 & 41.6 \\
\hline $36 / 91$ & $\|$ & 1.2 & $<0.5$ & 12.8 & 3.5 & 58.6 & 1.6 & $<0.5$ & 100.3 & 57.9 \\
\hline $37 / 91$ & $\|$ & 6.2 & $<0.5$ & 3.1 & 1.8 & 78.7 & 0.4 & $<0.5$ & 23.1 & 11.0 \\
\hline $38 / 91$ & $\|$ & 7.9 & $<0.5$ & 3.1 & 1.6 & 98.8 & 0.3 & $<0.5$ & 17.5 & 23.9 \\
\hline $39 / 91$ & ॥ & 7.3 & $<0.5$ & 7.9 & 1.4 & 82.5 & 1.6 & $<0.5$ & 50.1 & 65.8 \\
\hline $40 / 91$ & $\|$ & 9.9 & $<0.5$ & 8.3 & 2.0 & 77.4 & 1.4 & $<0.5$ & 55.1 & 56.4 \\
\hline $42 / 601$ & I (la) & 5.3 & 4.3 & 7.6 & 4.6 & 65.4 & 2.0 & $<0.5$ & 47.8 & 174.8 \\
\hline $43 / 601$ & I (la) & 6.2 & $<0.5$ & 11.1 & 3.6 & 61.4 & 1.3 & $<0.5$ & 46.8 & 68.1 \\
\hline $44 / 601$ & I (lb) & 10.5 & $<0.5$ & 7.0 & 2.7 & 97.4 & 1.7 & $<0.5$ & 52.8 & 42.8 \\
\hline $45 / 601$ & I (lb) & 8.0 & $<0.5$ & 4.8 & 3.5 & 108.5 & 1.1 & $<0.5$ & 30.7 & 31.9 \\
\hline $46 / 601$ & I (lb) & 10.5 & $<0.5$ & 5.8 & 2.7 & 99.6 & 1.5 & $<0.5$ & 60.9 & 23.4 \\
\hline $47 / 601$ & II & 13.6 & $<0.5$ & 4.5 & 2.6 & 106.7 & 0.9 & $<0.5$ & 35.8 & 157.9 \\
\hline $48 / 601$ & $\|$ & 2.7 & $<0.5$ & 10.8 & 2.3 & 82.5 & 1.7 & $<0.5$ & 67.2 & 239.7 \\
\hline $49 / 601$ & II & 33.0 & $<0.5$ & 6.1 & 1.8 & 105.1 & 1.7 & $<0.5$ & 42.0 & 155.5 \\
\hline $50 / 603$ & I (la) & 5.5 & $<0.5$ & 3.0 & 1.7 & 128.8 & 0.2 & $<0.5$ & 17.8 & 18.0 \\
\hline $51 / 603$ & I (Ib) & 5.4 & $<0.5$ & 2.1 & 1.3 & 177.7 & 0.2 & $<0.5$ & 15.0 & 26.0 \\
\hline $52 / 603$ & I (lb) & 0.4 & $<0.5$ & 1.2 & 1.6 & 253.1 & $<0.1$ & $<0.5$ & 7.6 & 11.2 \\
\hline $53 / 603$ & I (lb) & 36.1 & $<0.5$ & 11.2 & 2.8 & 94.9 & 3.7 & $<0.5$ & 76.8 & 98.2 \\
\hline $54 / 603$ & $\|$ & 3.7 & $<0.5$ & 2.1 & 1.4 & 176.1 & 0.1 & $<0.5$ & 13.3 & 26.5 \\
\hline $55 / 603$ & $\|$ & 18.2 & $<0.5$ & 6.1 & 3.3 & 100.7 & 2.4 & $<0.5$ & 49.9 & 54.4 \\
\hline $56 / 603$ & ॥ & 7.8 & $<0.5$ & 12.9 & 4.9 & 136.4 & 1.9 & $<0.5$ & 88.1 & 144.8 \\
\hline \multirow{2}{*}{$\begin{array}{l}\text { Clarke value of } \\
\text { brown coal }^{\mathrm{a}}\end{array}$} & & 10 & & 4.1 & 1.0 & 120 & 3.3 & & 22 & 18 \\
\hline & & \pm 0.9 & & \pm 0.2 & \pm 0.15 & \pm 10 & \pm 0.2 & & \pm 2 & \pm 1 \\
\hline
\end{tabular}




\begin{tabular}{|c|c|c|c|c|c|c|c|c|c|c|c|c|}
\hline Sample ID & Coal Seam & As & $\mathrm{Ba}$ & $\mathrm{Cd}$ & Co & $\mathrm{Cr}$ & $\mathrm{Cu}$ & $\mathrm{Ga}$ & $\mathrm{Li}$ & Mo & $\mathrm{Ni}$ & $\mathrm{Pb}$ \\
\hline $2 / 79$ & II & 29.5 & 43.5 & 1.5 & 6.4 & 52.2 & 21.7 & 3.2 & 9.5 & 4.0 & 65.1 & 24.3 \\
\hline $3 / 79$ & II & 30.3 & 122.7 & 2.4 & 16.9 & 125.3 & 69.0 & 19.8 & 84.8 & 7.4 & 83.2 & 80.2 \\
\hline $4 / 79$ & $\|$ & 33.6 & 72.6 & 1.5 & 26.3 & 65.6 & 24.6 & 7.0 & 17.3 & 5.4 & 73.4 & 31.8 \\
\hline $5 / 79$ & ॥ & 4.3 & 9.3 & 0.2 & 3.4 & 8.4 & 3.1 & 0.9 & 2.2 & 0.7 & 9.4 & 4.1 \\
\hline $6 / 79$ & $\|$ & $<0.5$ & 170.3 & 1.4 & 9.4 & 127.8 & 68.9 & 25.6 & 75.1 & 4.9 & 33.2 & 56.2 \\
\hline $8 / 79$ & $\|$ & 55.1 & 78.0 & 2.4 & 34.3 & 83.7 & 29.7 & 9.7 & 33.0 & 8.3 & 110.0 & 46.2 \\
\hline $11 / 79$ & III & $<0.5$ & 239.8 & 2.3 & 15.2 & 251.7 & 23.5 & 16.5 & 37.9 & 4.8 & 77.3 & 55.4 \\
\hline $14 / 79$ & III & 11.6 & 61.2 & 0.8 & 2.3 & 31.2 & 6.3 & 3.0 & 4.3 & 2.7 & 15.8 & 10.4 \\
\hline $15 / 79$ & III & 11.4 & 94.8 & 0.8 & 25.1 & 58.4 & 40.6 & 5.5 & 22.6 & 4.1 & 26.3 & 51.5 \\
\hline $16 / 79$ & III & 13.0 & 62.7 & 0.7 & 1.5 & 11.9 & 3.8 & 1.0 & 1.7 & 1.9 & 9.7 & 2.8 \\
\hline $17 / 79$ & III & 4.5 & 226.3 & 1.6 & 24.8 & 214.5 & 28.7 & 8.0 & 23.3 & 3.8 & 43.5 & 58.3 \\
\hline $18 / 79$ & III & 18.2 & 122.6 & 1.3 & 13.9 & 75.9 & 38.3 & 6.7 & 24.0 & 4.4 & 77.5 & 82.1 \\
\hline $19 / 79$ & III & 21.2 & 111.4 & 1.4 & 11.0 & 63.8 & 62.4 & 7.8 & 29.4 & 8.9 & 44.3 & 50.3 \\
\hline $20 / 79$ & III & 9.4 & 181.7 & 1.6 & 11.5 & 139.5 & 57.3 & 10.0 & 18.2 & 6.6 & 61.4 & 40.1 \\
\hline $21 / 79$ & III & $<0.5$ & 232.4 & 2.0 & 13.5 & 265.3 & 59.9 & 14.6 & 21.9 & 5.3 & 55.0 & 40.4 \\
\hline $24 / 79$ & & 39.0 & 190.4 & 2.0 & 21.8 & 94.6 & 5.2 & 5.4 & 9.9 & 3.7 & 33.2 & 80.9 \\
\hline $26 / 91$ & 1 & 10.5 & 91.1 & 1.4 & 7.6 & 74.1 & 45.8 & 14.3 & 45.4 & 5.2 & 31.6 & 60.2 \\
\hline $27 / 91$ & 1 & 19.8 & 74.8 & 1.1 & 7.8 & 41.9 & 21.0 & 4.7 & 8.0 & 4.4 & 24.0 & 19.5 \\
\hline 28/91 & 1 & 5.7 & 138.7 & 1.9 & 15.3 & 184.0 & 28.9 & 10.4 & 29.8 & 4.1 & 46.7 & 55.2 \\
\hline 29/91 & 1 & 16.1 & 72.0 & 1.2 & 7.6 & 43.0 & 28.1 & 6.2 & 17.2 & 3.9 & 64.2 & 38.8 \\
\hline $30 / 91$ & 1 & 56.7 & 123.8 & 3.1 & 11.9 & 108.8 & 62.6 & 13.6 & 35.8 & 8.9 & 47.7 & 76.8 \\
\hline $31 / 91$ & 1 & 140.0 & 142.3 & 6.5 & 35.8 & 371.4 & 3.6 & 13.4 & 9.5 & 8.7 & 214.0 & 111.4 \\
\hline $33 / 91$ & $\|$ & 22.8 & 108.2 & 1.7 & 14.6 & 113.9 & 58.0 & 11.7 & 39.7 & 4.6 & 135.1 & 110.0 \\
\hline $34 / 91$ & II & 35.0 & 80.9 & 1.8 & 11.1 & 82.9 & 34.4 & 5.8 & 16.9 & 6.7 & 131.7 & 49.2 \\
\hline $36 / 91$ & II & 28.7 & 100.3 & 2.3 & 23.2 & 126.1 & 65.1 & 19.4 & 82.8 & 7.4 & 110.6 & 179.9 \\
\hline $37 / 91$ & $\|$ & 31.8 & 62.3 & 1.5 & 8.6 & 47.5 & 11.0 & 5.7 & 16.7 & 4.2 & 34.8 & 20.0 \\
\hline $38 / 91$ & $\|$ & 4.4 & 72.2 & 0.5 & 2.5 & 29.8 & 11.6 & 3.4 & 14.6 & 1.4 & 13.2 & 21.6 \\
\hline $39 / 91$ & II & 10.5 & 122.1 & 1.3 & 7.3 & 96.0 & 46.6 & 11.2 & 42.8 & 4.8 & 31.2 & 113.9 \\
\hline $40 / 91$ & II & 4.6 & 99.2 & 1.1 & 7.0 & 76.9 & 41.1 & 11.9 & 47.2 & 4.9 & 25.2 & 115.2 \\
\hline $42 / 601$ & I (la) & 36.7 & 90.7 & 2.4 & 24.5 & 106.1 & 45.3 & 10.1 & 34.7 & 11.5 & 91.5 & 96.4 \\
\hline $43 / 601$ & I (la) & 24.3 & 65.0 & 2.0 & 20.1 & 93.3 & 27.4 & 9.5 & 23.5 & 7.7 & 36.2 & 91.4 \\
\hline $44 / 601$ & I (lb) & 34.9 & 58.4 & 2.1 & 10.5 & 101.4 & 54.3 & 9.3 & 26.2 & 8.1 & 47.3 & 54.2 \\
\hline $45 / 601$ & I (lb) & 21.5 & 63.4 & 1.8 & 8.0 & 78.7 & 38.7 & 8.9 & 21.1 & 5.4 & 63.3 & 82.4 \\
\hline $46 / 601$ & I (lb) & 15.8 & 96.7 & 1.7 & 9.8 & 149.6 & 24.5 & 7.4 & 17.4 & 5.0 & 43.0 & 116.3 \\
\hline $47 / 601$ & II & 70.4 & 48.1 & 3.2 & 21.9 & 86.2 & 39.9 & 6.7 & 21.7 & 6.8 & 206.1 & 40.7 \\
\hline $48 / 601$ & II & 39.1 & 100.1 & 2.6 & 11.9 & 150.9 & 30.7 & 20.0 & 85.1 & 9.8 & 92.9 & 74.8 \\
\hline $49 / 601$ & II & 15.8 & 94.6 & 1.4 & 7.7 & 84.4 & 29.1 & 9.8 & 33.6 & 4.3 & 50.6 & 107.0 \\
\hline $50 / 603$ & I (la) & 28.1 & 47.5 & 1.6 & 6.5 & 59.5 & 15.2 & 4.3 & 11.0 & 4.3 & 35.7 & 26.2 \\
\hline $51 / 603$ & I (lb) & 4.0 & 40.9 & 0.6 & 3.4 & 36.6 & 8.0 & 2.1 & 8.8 & 1.1 & 13.7 & 16.9 \\
\hline $52 / 603$ & I (lb) & 17.7 & 77.8 & 0.9 & 8.8 & 35.2 & 3.5 & 2.3 & 3.8 & 2.8 & 19.5 & 6.9 \\
\hline $53 / 603$ & I (lb) & 31.1 & 173.1 & 2.4 & 16.7 & 191.0 & 72.5 & 16.3 & 54.1 & 8.9 & 148.5 & 175.7 \\
\hline $54 / 603$ & II & 24.9 & 34.9 & 1.2 & 6.6 & 39.8 & 8.6 & 3.2 & 8.6 & 2.5 & 26.9 & 14.5 \\
\hline $55 / 603$ & II & 12.7 & 156.5 & 2.2 & 11.3 & 226.7 & 71.3 & 16.2 & 43.0 & 4.3 & 74.5 & 52.9 \\
\hline $56 / 603$ & II & $<0.5$ & 138.7 & 1.7 & 33.7 & 216.8 & 77.2 & 22.9 & 46.5 & 5.6 & 45.4 & 70.4 \\
\hline $\begin{array}{l}\text { Clarke value of } \\
\text { brown coal }^{\mathrm{a}}\end{array}$ & & $\begin{array}{r}7.6 \\
\pm 1.3\end{array}$ & $\begin{array}{l}150 \\
\pm 20\end{array}$ & $\begin{array}{r}0.24 \\
\pm 0.04\end{array}$ & $\begin{array}{r}4.2 \\
\pm 0.3\end{array}$ & $\begin{array}{l}15 \\
\pm 1\end{array}$ & $\begin{array}{l}15 \\
\pm 1\end{array}$ & $\begin{array}{r}5.5 \\
\pm 0.3\end{array}$ & $\begin{array}{r}10 \\
\pm 1\end{array}$ & $\begin{array}{r}2.2 \\
\pm 0.2\end{array}$ & $\begin{array}{r}9.0 \\
\pm 0.9\end{array}$ & $\begin{array}{r}6.6 \\
\pm 0.4\end{array}$ \\
\hline
\end{tabular}

${ }^{a}$ KETRIS \& YUDOVICH (2009) 
Table S-VI. Content of Rare earth elements and yttrium (REY, mg/kg) of individual samples.

\begin{tabular}{|c|c|c|c|c|c|c|c|c|c|c|c|}
\hline Sample ID & Coal Seam & $\mathrm{La}$ & $\mathrm{Ce}$ & $\operatorname{Pr}$ & $\mathrm{Nd}$ & $\mathrm{Sm}$ & $\mathrm{Eu}$ & $\mathrm{Gd}$ & $\mathrm{Tb}$ & Dy & Y \\
\hline $2 / 79$ & ॥ & 5.78 & 10.10 & 3.60 & 6.20 & 0.70 & 0.48 & 4.76 & 1.10 & 1.34 & 6.64 \\
\hline $3 / 79$ & II & 4.39 & 10.30 & 2.10 & 4.00 & 1.50 & 0.59 & 13.02 & 2.60 & 1.09 & 6.79 \\
\hline $4 / 79$ & ॥ & 6.37 & 13.00 & 3.10 & 5.90 & 1.00 & 0.59 & 5.92 & $<0.1$ & 1.00 & 5.94 \\
\hline $5 / 79$ & $\|$ & 0.81 & 1.70 & 0.40 & 0.80 & 0.10 & 0.08 & 0.76 & $<0.1$ & 0.13 & 0.76 \\
\hline $6 / 79$ & II & 2.11 & 3.80 & 0.90 & 1.50 & 1.30 & 0.31 & 14.38 & 4.50 & 0.29 & 2.39 \\
\hline $8 / 79$ & $\|$ & 7.61 & 15.40 & 4.00 & 8.30 & 1.70 & 0.83 & 7.19 & $<0.1$ & 1.94 & 13.47 \\
\hline $11 / 79$ & III & 8.24 & 20.15 & 5.40 & 7.70 & 1.50 & 0.84 & 12.92 & 3.00 & 1.40 & 7.11 \\
\hline $14 / 79$ & III & 3.19 & 5.80 & 2.20 & 3.40 & 0.50 & 0.28 & 3.49 & 0.70 & 0.75 & 5.27 \\
\hline $15 / 79$ & III & 7.44 & 12.10 & 4.20 & 6.50 & 0.50 & 0.40 & 6.40 & $<0.1$ & 1.06 & 4.77 \\
\hline $16 / 79$ & III & 1.90 & 2.70 & 1.40 & 1.70 & 0.10 & 0.15 & 2.48 & 0.50 & 0.11 & 0.99 \\
\hline $17 / 79$ & III & 15.21 & 21.40 & 7.10 & 10.80 & 0.80 & 0.70 & 11.74 & 0.50 & 1.63 & 8.61 \\
\hline $18 / 79$ & III & 9.28 & 14.50 & 4.70 & 8.00 & 0.90 & 0.57 & 7.94 & 0.60 & 1.37 & 7.60 \\
\hline $19 / 79$ & III & 8.78 & 13.80 & 5.10 & 8.30 & 1.00 & 0.54 & 8.14 & 1.20 & 1.41 & 7.72 \\
\hline 20/79 & III & 11.59 & 19.40 & 5.40 & 9.00 & 1.10 & 0.78 & 9.79 & 1.50 & 1.41 & 8.67 \\
\hline $21 / 79$ & III & 6.80 & 15.40 & 3.70 & 5.90 & 1.60 & 0.70 & 14.57 & 3.10 & 1.21 & 6.85 \\
\hline $24 / 79$ & & 8.03 & 12.65 & 4.20 & 5.65 & 0.50 & 0.45 & 6.17 & $<0.1$ & 0.91 & 5.64 \\
\hline $26 / 91$ & 1 & 3.70 & 8.50 & 2.10 & 3.90 & 1.20 & 0.48 & 8.54 & 2.10 & 0.75 & 4.62 \\
\hline $27 / 91$ & I & 4.16 & 7.50 & 2.00 & 3.70 & 0.60 & 0.35 & 4.37 & 0.40 & 0.51 & 3.30 \\
\hline $28 / 91$ & I & 12.86 & 18.40 & 5.30 & 9.00 & 1.10 & 0.71 & 9.92 & 1.10 & 1.64 & 9.17 \\
\hline $29 / 91$ & I & 5.10 & 8.00 & 2.80 & 4.20 & 0.50 & 0.31 & 5.22 & 0.90 & 0.54 & 3.60 \\
\hline $30 / 91$ & I & 6.53 & 13.80 & 2.80 & 5.40 & 1.40 & 0.62 & 8.66 & 1.60 & 0.71 & 5.11 \\
\hline $31 / 91$ & I & 9.94 & 28.70 & 1.80 & 7.60 & 2.20 & 1.59 & 7.12 & $<0.1$ & 2.54 & 12.79 \\
\hline $33 / 91$ & $\|$ & 10.24 & 17.80 & 5.20 & 9.00 & 1.10 & 0.71 & 8.69 & 0.80 & 1.60 & 9.47 \\
\hline $34 / 91$ & II & 9.80 & 17.60 & 5.40 & 9.90 & 0.90 & 0.71 & 5.97 & $<0.1$ & 1.78 & 9.55 \\
\hline $36 / 91$ & II & 3.33 & 9.00 & 2.10 & 2.85 & 1.50 & 0.54 & 11.89 & 2.25 & 0.72 & 5.03 \\
\hline $37 / 91$ & II & 4.86 & 10.30 & 2.60 & 4.90 & 0.60 & 0.48 & 4.54 & 0.70 & 0.76 & 5.34 \\
\hline $38 / 91$ & II & 4.01 & 6.00 & 2.60 & 4.00 & 0.40 & 0.27 & 3.95 & 0.50 & 0.83 & 5.03 \\
\hline $39 / 91$ & II & 6.35 & 11.40 & 3.90 & 6.40 & 1.20 & 0.54 & 8.77 & 1.70 & 1.33 & 8.61 \\
\hline $40 / 91$ & II & 4.89 & 9.60 & 3.00 & 5.20 & 1.20 & 0.50 & 8.32 & 2.00 & 1.17 & 7.36 \\
\hline $42 / 601$ & I (la) & 8.46 & 14.60 & 4.30 & 7.90 & 1.30 & 0.73 & 9.58 & 0.20 & 1.80 & 12.34 \\
\hline $43 / 601$ & I (la) & 8.29 & 14.70 & 4.60 & 8.50 & 1.70 & 0.92 & 11.18 & 0.90 & 2.68 & 17.54 \\
\hline $44 / 601$ & I (lb) & 8.33 & 16.10 & 4.40 & 8.00 & 1.60 & 0.80 & 7.76 & 0.80 & 1.63 & 11.12 \\
\hline $45 / 601$ & I (lb) & 8.31 & 13.00 & 3.90 & 6.50 & 0.80 & 0.51 & 8.46 & 1.30 & 0.87 & 5.11 \\
\hline $46 / 601$ & I (lb) & 8.73 & 13.95 & 4.05 & 6.80 & 0.90 & 0.59 & 7.11 & 0.75 & 1.32 & 7.62 \\
\hline $47 / 601$ & ॥ & 5.00 & 9.70 & 2.90 & 5.00 & 1.00 & 0.51 & 4.96 & $<0.1$ & 1.26 & 9.56 \\
\hline $48 / 601$ & $\|$ & 4.47 & 13.50 & 2.15 & 4.15 & 1.60 & 0.71 & 11.38 & 2.50 & 0.54 & 4.74 \\
\hline $49 / 601$ & II & 8.33 & 12.10 & 3.80 & 6.30 & 0.80 & 0.46 & 7.23 & 1.40 & 0.93 & 5.87 \\
\hline $50 / 603$ & I (la) & 5.26 & 9.30 & 3.10 & 4.70 & 0.60 & 0.41 & 4.63 & 0.60 & 0.81 & 5.70 \\
\hline $51 / 603$ & I (lb) & 3.61 & 5.00 & 2.30 & 2.90 & 0.20 & 0.23 & 3.53 & 0.50 & 0.81 & 4.37 \\
\hline $52 / 603$ & I (lb) & 3.56 & 5.85 & 2.00 & 3.00 & 0.15 & 0.25 & 3.80 & $<0.1$ & 0.33 & 2.09 \\
\hline $53 / 603$ & I (lb) & 11.95 & 21.20 & 5.90 & 10.20 & 1.90 & 0.94 & 11.05 & 1.40 & 2.05 & 14.94 \\
\hline $54 / 603$ & II & 3.03 & 5.40 & 1.80 & 2.60 & 0.40 & 0.25 & 3.54 & 0.10 & 0.49 & 3.03 \\
\hline $55 / 603$ & II & 10.77 & 15.90 & 4.50 & 7.70 & 1.00 & 0.59 & 11.93 & 1.90 & 1.27 & 7.57 \\
\hline $56 / 603$ & II & 6.12 & 12.50 & 2.30 & 4.70 & 1.40 & 0.65 & 15.70 & 2.00 & 0.84 & 4.94 \\
\hline Clarke value & & 10 & 22 & 3.5 & 11 & 1.9 & 0.5 & 2.6 & 0.32 & 2.0 & 8.6 \\
\hline of brown coala & & \pm 0.5 & \pm 1 & \pm 0.3 & \pm 1 & \pm 0.1 & \pm 0.02 & \pm 0.2 & \pm 0.03 & \pm 0.1 & \pm 0.4 \\
\hline
\end{tabular}

$\mathrm{LREY}=\mathrm{La}+\mathrm{Ce}+\mathrm{Pr}+\mathrm{Nd}+\mathrm{Sm} ; \mathrm{MREY}=\mathrm{Eu}+\mathrm{Gd}+\mathrm{Tb}+\mathrm{Dy}+\mathrm{Y} ; \mathrm{HREY}=\mathrm{Ho}+\mathrm{Er}+\mathrm{Tm}+\mathrm{Yb}+\mathrm{Lu}$; (SEREDIN \& DAI, 2012). 


\begin{tabular}{|c|c|c|c|c|c|c|c|c|c|c|}
\hline Sample ID & Coal Seam & $\mathrm{Ho}$ & Er & $\mathrm{Tm}$ & $\mathrm{Yb}$ & $\mathrm{Lu}$ & LREYb $^{b}$ & MREYb & HREYb & $\sum$ REY \\
\hline $2 / 79$ & II & 0.32 & 0.89 & 0.26 & 0.81 & 0.35 & 26.38 & 14.54 & 2.62 & 43.54 \\
\hline $3 / 79$ & II & 0.69 & 1.41 & 0.20 & 1.70 & 0.90 & 22.29 & 25.00 & 4.90 & 52.19 \\
\hline $4 / 79$ & II & 0.49 & 1.10 & 0.23 & 1.13 & 0.67 & 29.37 & 13.86 & 3.61 & 46.84 \\
\hline $5 / 79$ & II & 0.06 & 0.14 & 0.03 & 0.14 & 0.09 & 3.81 & 1.75 & 0.46 & 6.02 \\
\hline $6 / 79$ & II & 0.54 & 0.79 & 0.09 & 1.14 & 0.61 & 9.61 & 22.86 & 3.17 & 35.64 \\
\hline $8 / 79$ & II & 0.80 & 1.92 & 0.34 & 2.00 & 0.89 & 37.01 & 24.30 & 5.95 & 67.26 \\
\hline $11 / 79$ & III & 0.87 & 1.23 & 0.30 & 1.36 & 0.91 & 42.99 & 25.26 & 4.66 & 72.91 \\
\hline $14 / 79$ & III & 0.27 & 0.76 & 0.26 & 0.64 & 0.24 & 15.09 & 10.49 & 2.17 & 27.75 \\
\hline $15 / 79$ & III & 0.32 & 0.80 & 0.28 & 0.80 & 0.27 & 30.74 & 12.63 & 2.47 & 45.84 \\
\hline $16 / 79$ & III & 0.05 & 0.21 & 0.08 & 0.15 & 0.13 & 7.80 & 4.23 & 0.61 & 12.64 \\
\hline $17 / 79$ & III & 0.85 & 1.13 & 0.36 & 1.13 & 0.67 & 55.31 & 23.18 & 4.14 & 82.63 \\
\hline $18 / 79$ & III & 0.44 & 1.08 & 0.33 & 1.08 & 0.44 & 37.38 & 18.08 & 3.37 & 58.83 \\
\hline $19 / 79$ & III & 0.48 & 1.14 & 0.38 & 1.19 & 0.37 & 36.98 & 19.01 & 3.56 & 59.54 \\
\hline $20 / 79$ & III & 0.63 & 1.22 & 0.25 & 1.22 & 0.78 & 46.49 & 22.15 & 4.10 & 72.74 \\
\hline $21 / 79$ & III & 0.93 & 1.22 & 0.20 & 1.38 & 0.85 & 33.40 & 26.43 & 4.58 & 64.41 \\
\hline $24 / 79$ & & 0.34 & 0.72 & 0.21 & 0.75 & 0.47 & 31.03 & 13.16 & 2.47 & 46.66 \\
\hline $26 / 91$ & 1 & 0.42 & 0.95 & 0.12 & 1.02 & 0.64 & 19.40 & 16.49 & 3.15 & 39.04 \\
\hline $27 / 91$ & I & 0.18 & 0.58 & 0.13 & 0.60 & 0.43 & 17.96 & 8.93 & 1.91 & 28.80 \\
\hline $28 / 91$ & 1 & 0.71 & 1.29 & 0.39 & 1.42 & 0.75 & 46.66 & 22.54 & 4.56 & 73.76 \\
\hline 29/91 & 1 & 0.26 & 0.64 & 0.14 & 0.63 & 0.33 & 20.60 & 10.57 & 2.00 & 33.17 \\
\hline $30 / 91$ & 1 & 0.51 & 1.05 & 0.18 & 1.13 & 0.92 & 29.93 & 16.70 & 3.79 & 50.42 \\
\hline $31 / 91$ & 1 & 1.35 & 2.45 & 0.29 & 2.71 & 2.65 & 50.24 & 24.04 & 9.45 & 83.73 \\
\hline $33 / 91$ & II & 0.60 & 1.25 & 0.36 & 1.44 & 0.70 & 43.34 & 21.66 & 4.35 & 69.35 \\
\hline $34 / 91$ & II & 0.52 & 1.20 & 0.34 & 1.18 & 0.49 & 43.60 & 18.20 & 3.73 & 65.53 \\
\hline $36 / 91$ & II & 0.58 & 1.17 & 0.17 & 1.48 & 0.84 & 18.78 & 21.39 & 4.23 & 44.39 \\
\hline $37 / 91$ & II & 0.27 & 0.76 & 0.23 & 0.79 & 0.54 & 23.26 & 11.94 & 2.59 & 37.79 \\
\hline $38 / 91$ & II & 0.22 & 0.63 & 0.12 & 0.56 & 0.19 & 17.01 & 10.71 & 1.72 & 29.44 \\
\hline $39 / 91$ & II & 0.49 & 1.16 & 0.21 & 1.21 & 0.49 & 29.25 & 21.61 & 3.56 & 54.42 \\
\hline $40 / 91$ & II & 0.49 & 1.11 & 0.18 & 1.13 & 0.51 & 23.89 & 20.05 & 3.42 & 47.36 \\
\hline $42 / 601$ & I (la) & 0.69 & 1.87 & 0.38 & 1.71 & 0.75 & 36.56 & 24.65 & 5.40 & 66.61 \\
\hline $43 / 601$ & I (la) & 0.86 & 2.38 & 0.52 & 2.45 & 0.90 & 37.79 & 33.22 & 7.11 & 78.12 \\
\hline $44 / 601$ & I (lb) & 0.62 & 1.52 & 0.31 & 1.53 & 0.88 & 38.43 & 22.11 & 4.86 & 65.40 \\
\hline $45 / 601$ & I (lb) & 0.34 & 0.83 & 0.25 & 0.87 & 0.60 & 32.51 & 16.25 & 2.89 & 51.66 \\
\hline $46 / 601$ & I (lb) & 0.50 & 1.17 & 0.31 & 1.20 & 0.62 & 34.43 & 17.38 & 3.80 & 55.61 \\
\hline $47 / 601$ & ॥ & 0.45 & 1.29 & 0.32 & 1.21 & 0.59 & 23.60 & 16.78 & 3.85 & 44.23 \\
\hline $48 / 601$ & ॥ & 0.60 & 1.22 & 0.16 & 1.41 & 1.19 & 25.87 & 20.75 & 4.58 & 51.19 \\
\hline $49 / 601$ & II & 0.44 & 0.82 & 0.26 & 0.90 & 0.46 & 31.33 & 16.23 & 2.89 & 50.45 \\
\hline $50 / 603$ & I (la) & 0.23 & 0.77 & 0.25 & 0.74 & 0.40 & 22.96 & 12.15 & 2.40 & 37.51 \\
\hline $51 / 603$ & I (lb) & 0.18 & 0.49 & 0.19 & 0.50 & 0.14 & 14.01 & 9.44 & 1.50 & 24.95 \\
\hline $52 / 603$ & I (lb) & 0.04 & 0.40 & 0.13 & 0.31 & 0.28 & 14.56 & 6.46 & 1.16 & 22.17 \\
\hline $53 / 603$ & I (lb) & 0.79 & 1.87 & 0.52 & 2.02 & 1.03 & 51.15 & 30.38 & 6.22 & 87.75 \\
\hline $54 / 603$ & II & 0.10 & 0.52 & 0.13 & 0.45 & 0.26 & 13.23 & 7.56 & 1.46 & 22.25 \\
\hline $55 / 603$ & II & 0.77 & 1.03 & 0.31 & 1.26 & 0.64 & 39.87 & 23.67 & 4.01 & 67.55 \\
\hline $56 / 603$ & II & 0.79 & 1.10 & 0.17 & 1.53 & 1.15 & 27.02 & 24.88 & 4.75 & 56.65 \\
\hline $\begin{array}{l}\text { Clarke value of } \\
\text { brown coal }^{\mathrm{a}}\end{array}$ & & $\begin{array}{r}0.50 \\
\pm 0.05\end{array}$ & $\begin{array}{r}0.85 \\
\pm 0.08\end{array}$ & $\begin{array}{r}0.31 \\
\pm 0.02\end{array}$ & $\begin{array}{r}1.0 \\
\pm 0.05\end{array}$ & $\begin{array}{r}0.19 \\
\pm 0.02\end{array}$ & & & & \\
\hline
\end{tabular}

${ }^{\mathrm{a}}$ KETRIS \& YUDOVICH (2009); ${ }^{\mathrm{b}}$ SEREDIN \& DAI (2012) 
Table S-VII. Element affinities deduced from calculation of Pearson's correlation coefficients between the concentration of each element in the coal and ash yield, $\mathrm{Si}, \mathrm{Al}$ and total sulphur content.

\begin{tabular}{|c|c|c|c|}
\hline & I seam & II seam & III seam \\
\hline \multicolumn{4}{|c|}{ Correlation with ash yield } \\
\hline$r_{\text {ash }}=0.7-1.0$ & $\begin{array}{l}\mathrm{Al}(0.75), \mathrm{Si}(0.95), \mathrm{Ti}(0.80), \mathrm{K}(0.85), \mathrm{Ba}(0.81), \\
\mathrm{Cr}(0.75), \mathrm{Ga}(0.92), \mathrm{Pb}(0.71), \mathrm{Rb}(0.73), \mathrm{Sc}(0.73), \\
\mathrm{V}(0.79), \mathrm{La}(0.74), \mathrm{Ce}(0.81), \mathrm{Nd}(0.70), \mathrm{Sm}(0.81), \\
\mathrm{Eu}(0.74), \mathrm{Gd}(0.78), \mathrm{Ho}(0.79), \mathrm{Yb}(0.72), \\
\operatorname{LREY}(0.80), \operatorname{MREY}(0.72), \operatorname{HREY}(0.74)\end{array}$ & $\begin{array}{l}\mathrm{Al}(0.84), \mathrm{Si}(0.95), \mathrm{Ti}(0.97), \mathrm{Ba}(0.80), \mathrm{Cr}(0.83), \\
\mathrm{Cu}(0.84), \mathrm{Ga}(0.95), \mathrm{Li}(0.86), \mathrm{Sc}(0.88), \mathrm{Se}(0.70), \\
\text { V }(0.80), \mathrm{Gd}(0.93), \mathrm{Tb}(0.82)\end{array}$ & $\begin{array}{l}\mathrm{Al}(0.93), \mathrm{Si}(0.99), \mathrm{Ti}(0.94), \mathrm{Fe}(0.95), \mathrm{K}(0.97) \\
\mathrm{Na}(0.92), \mathrm{Mn}(0.83), \mathrm{Si} / \mathrm{Al}(0.96), \mathrm{Ba}(0.98), \\
\mathrm{Cd}(0.94), \mathrm{Cr}(0.96), \mathrm{Ga}(0.94), \mathrm{Ni}(0.72), \mathrm{Sc}(0.77), \\
\mathrm{Th}(0.82), \mathrm{Zn}(0.90), \mathrm{Ce}(0.85), \mathrm{Sm}(0.86), \mathrm{Eu}(0.93), \\
\mathrm{Gd}(0.94), \mathrm{Tb}(0.77), \mathrm{Ho}(0.94), \operatorname{Er}(0.76), \mathrm{Yb}(0.82), \\
\mathrm{Lu}(0.99), \operatorname{LREY}(0.74), \mathrm{MREY}(0.91), \operatorname{HREY}(0.89) .\end{array}$ \\
\hline$r_{\text {ash }}=0.50-0.69$ & $\begin{array}{l}\text { Fe (0.68), } \mathrm{Na}(0.56), \mathrm{Cd}(0.65), \mathrm{Co}(0.62), \mathrm{Li}(0.68), \\
\mathrm{Mo}(0.56), \mathrm{Ni}(0.65), \mathrm{Se}(0.59), \operatorname{Th}(0.67), \mathrm{Tb}(0.69), \\
\mathrm{Dy}(0.62), \mathrm{Y}(0.57), \operatorname{Er}(0.66), \operatorname{Tm}(0.51), \mathrm{Lu}(0.69) .\end{array}$ & $\begin{array}{l}\mathrm{Fe}(0.63), \mathrm{K}(0.55), \mathrm{Na}(0.59), \mathrm{Pb}(0.54), \mathrm{Th}(0.58), \\
\mathrm{Sm}(0.66), \mathrm{Eu}(0.66), \mathrm{Ho}(0.66), \mathrm{Yb}(0.53), \mathrm{Lu}(0.68), \\
\text { HREY (0.50). }\end{array}$ & $\begin{array}{l}\mathrm{Li}(0.66), \mathrm{V}(0.58), \mathrm{La}(0.57), \operatorname{Pr}(0.64), \mathrm{Nd}(0.59), \\
\operatorname{Dy}(0.66), \mathrm{Y}(0.63)\end{array}$ \\
\hline$r_{\text {ash }}=0.35-0.49$ & $\begin{array}{l}\mathrm{S}^{\mathrm{db}}(0.41), \mathrm{Mg}(0.40), \mathrm{Mn}(0.45), \mathrm{As}(0.45) \\
\mathrm{Cu}(0.48), \mathrm{Zn}(0.44), \operatorname{Pr}(0.42)\end{array}$ & Mo (0.42), Zn (0.45). & $\begin{array}{l}\mathrm{Mg}(0.49), \mathrm{Co}(0.43), \mathrm{Cu}(0.39), \mathrm{Mo}(0.32), \mathrm{Pb}(0.41) \\
\mathrm{Rb}(0.47), \mathrm{Se}(0.42)\end{array}$ \\
\hline$r_{\text {ash }}=-0.34-0.34$ & Ca $(-0.33)$ & $\begin{array}{l}\operatorname{Mg}(-0.11), \operatorname{Mn}(-0.05), \operatorname{As}(-0.13), \mathrm{Cd}(0.32), \mathrm{Co}(0.28), \\
\mathrm{Ni}(-0.02), \operatorname{Rb}(-0.01), \operatorname{Sr}(-0.18), \operatorname{La}(-0.04), \mathrm{Ce}(0.07), \\
\operatorname{Pr}(-0.22), \mathrm{Nd}(-0.22), \operatorname{Dy}(-0.23), \mathrm{Y}(-0.19), \operatorname{Er}(0.23) \\
\operatorname{Tm}(-0.22), \operatorname{LREY}(-0.03), \operatorname{MREY}(0.01)\end{array}$ & $\operatorname{Tm}(0.22)$ \\
\hline$r_{\text {ash }}=-1.0--0.35$ & $\operatorname{Sr}(-0.45)$ & $\mathrm{S}^{\mathrm{db}}(-0.40), \mathrm{Ca}(-0.41)$ & $\mathrm{Ca}(-0.81), \mathrm{As}(-0.52), \operatorname{Sr}(-0.72)$ \\
\hline \multicolumn{4}{|c|}{ Correlation with total sulphur content } \\
\hline$r_{\text {Stot }}=0.7-1.0$ & $\mathrm{Fe}(0.79), \mathrm{As}(0.79), \mathrm{Cd}(0.78), \mathrm{Se}(0.76)$ & As (0.76). & \\
\hline$r_{\text {Stot }}=0.5-0.69$ & $\operatorname{Mn}(0.60), \mathrm{Co}(0.65), \mathrm{Cr}(0.58), \mathrm{Mo}(0.66)$ & Mo $(0.50)$ & $\operatorname{Sr}(0.69)$ \\
\hline$r_{\text {Stot }}=0.35-0.49$ & $\mathrm{Na}(0.35), \mathrm{Ga}(0.47), \mathrm{Ni}(0.49), \mathrm{Sc}(0,35), \mathrm{V}(0.37)$ & $\mathrm{Fe}(0.39), \mathrm{Cd}(0.48), \mathrm{Ni}(0.42)$ & As (0.38). \\
\hline
\end{tabular}

$\mathrm{S}^{\mathrm{db}}$ - total sulphur content, dry basis wt.\%

Table S-VII. Continuied.

\begin{tabular}{|c|c|c|c|}
\hline & I seam & II seam & III seam \\
\hline \multicolumn{4}{|l|}{ Al affinity } \\
\hline $\mathrm{r}_{\mathrm{Al}}=0.7-1.0$ & $\begin{array}{l}\mathrm{Si}(0.78), \mathrm{Ti}(0.87), \mathrm{Cu}(0.85), \mathrm{Ga}(0.86), \mathrm{Li}(0.94) \text {, } \\
\mathrm{Sc}(0.79), \mathrm{Th}(0.81), \mathrm{V}(0.73), \mathrm{Gd}(0.76), \mathrm{Tb}(0.85) \text {. }\end{array}$ & $\begin{array}{l}\mathrm{Si}(0.88), \mathrm{Ti}(0.84), \mathrm{K}(0.74), \mathrm{Ba}(0.86), \mathrm{Cr}(0.75) \\
\mathrm{Cu}(0.86), \mathrm{Ga}(0.86), \mathrm{Li}(0.90), \mathrm{Pb}(0.74), \mathrm{Sc}(0.86), \\
\mathrm{Th}(0.76), \mathrm{V}(0.84), \mathrm{Sm}(0.77), \mathrm{Eu}(0.77), \mathrm{Gd}(0.88) \\
\mathrm{Tb}(0.73), \mathrm{Ho}(0.75)\end{array}$ & $\begin{array}{l}\mathrm{Si}(0.93), \mathrm{Ti}(0.95), \mathrm{Fe}(0.87), \mathrm{K}(0.91), \mathrm{Na}(0.81) \text {, } \\
\mathrm{Mn}(0.77), \mathrm{Si} / \mathrm{Al}(0.85), \mathrm{Ba}(0.93), \mathrm{Cd}(0.96), \mathrm{Cr}(0.90) \text {, } \\
\mathrm{Ga}(0.96), \mathrm{Li}(0.87), \mathrm{Ni}(0.82), \mathrm{Sc}(0.93), \mathrm{Th}(0.92), \\
\text { V (0.82), Zn (0.95), } \mathrm{Ce}(0.90), \operatorname{Pr}(0.74), \mathrm{Nd}(0.71), \\
\mathrm{Sm}(0.93), \mathrm{Eu}(0.95), \mathrm{Gd}(0.96), \mathrm{Tb}(0.75), \mathrm{Dy}(0.81), \\
\text { Y (0.74), } \mathrm{Ho}(0.94), \operatorname{Er}(0.88), \mathrm{Yb}(0.95), \mathrm{Lu}(0.93), \\
\text { LREY (0.81), MREY (0.96), HREY (0.95). }\end{array}$ \\
\hline$r_{A l}=0.5-0.69$ & $\begin{array}{l}\mathrm{Mg}(0.54), \mathrm{K}(0.64), \mathrm{Ba}(0.61), \mathrm{Pb}(0.60), \mathrm{Rb}(0.55) \text {, } \\
\mathrm{Sm}(0.54), \mathrm{MREY}(0.52) .\end{array}$ & $\begin{array}{l}\mathrm{Fe}(0.60), \mathrm{Na}(0.53), \mathrm{Mo}(0.53), \mathrm{Se}(0.63), \operatorname{Er}(0.50) \\
\mathrm{Yb}(0.70), \mathrm{Lu}(0.63), \mathrm{HREY}(0.65)\end{array}$ & $\begin{array}{l}\mathrm{Mg}(0.62), \mathrm{Co}(0.54), \mathrm{Cu}(0.56), \mathrm{Mo}(0.53), \mathrm{Pb}(0.63) \\
\mathrm{Se}(0.58), \mathrm{La}(0.63)\end{array}$ \\
\hline \multicolumn{4}{|l|}{ Si affinity } \\
\hline $\mathrm{r}_{\mathrm{Si}}=0.7-1.0$ & $\begin{array}{l}\mathrm{Al}(0.78), \mathrm{Ti}(0.85), \mathrm{K}(0.87), \mathrm{Ba}(0.80), \mathrm{Cr}(0.71), \\
\mathrm{Ga}(0.88), \mathrm{Li}(0.71), \mathrm{Pb}(0.78), \mathrm{Rb}(0.74), \mathrm{Sc}(0.78), \\
\mathrm{Th}(0.75), \mathrm{V}(0.88), \mathrm{La}(0.80), \mathrm{Ce}(0.76), \mathrm{Nd}(0.75), \\
\mathrm{Sm}(0.75), \mathrm{Gd}(0.83), \mathrm{Ho}(0.74), \mathrm{LREY}(0.81), \\
\operatorname{MREY}(0.75) \text {. }\end{array}$ & $\begin{array}{l}\mathrm{Ti}(0.95), \mathrm{Na}(0.77), \mathrm{Ba}(0.89), \mathrm{Cr}(0.93), \mathrm{Cu}(0.90), \\
\mathrm{Ga}(0.93), \mathrm{Li}(0.71), \mathrm{Sc}(0.82), \mathrm{Se}(0.80), \mathrm{V}(0.76) \\
\mathrm{Gd}(0.96), \mathrm{Tb}(0.72), \mathrm{Ho}(0.75)\end{array}$ & $\begin{array}{l}\mathrm{Ti}(0.97), \mathrm{Fe}(0.94), \mathrm{K}(0.96), \mathrm{Na}(0.92), \mathrm{Mn}(0.83), \\
\mathrm{Ba}(0.98), \mathrm{Cd}(0.95), \mathrm{Cr}(0.98), \mathrm{Ga}(0.95), \mathrm{Ni}(0.71), \\
\mathrm{Sc}(0.79), \mathrm{Th}(0.90), \mathrm{Ce}(0.81), \mathrm{Sm}(0.88), \mathrm{Eu}(0.90), \\
\mathrm{Gd}(0.95), \mathrm{Tb}(0.81), \mathrm{Ho}(0.95), \mathrm{Er}(0.74), \mathrm{Yb}(0.81), \\
\mathrm{Lu}(0.98), \mathrm{MREY}(0.90), \operatorname{HREY}(0.88) .\end{array}$ \\
\hline$r_{\mathrm{Si}}=0.5-0.69$ & $\begin{array}{l}\mathrm{Fe}(0.55), \mathrm{Na}(0.55), \mathrm{Co}(0.53), \mathrm{Ni}(0.54), \operatorname{Pr}(0.55) \\
\mathrm{Eu}(0.67), \mathrm{Tb}(0.63), \mathrm{Dy}(0.62), \mathrm{Y}(0.59), \operatorname{Er}(0.64), \\
\operatorname{Tm}(0.59), \mathrm{Yb}(0.69), \operatorname{Lu}(0.57), \operatorname{HREY}(0.69)\end{array}$ & $\begin{array}{l}\mathrm{Fe}(0.61), \mathrm{K}(0.69), \mathrm{Pb}(0.56), \operatorname{Th}(0.67), \mathrm{Sm}(0.67) \\
\mathrm{Eu}(0.67), \mathrm{Yb}(0.59), \mathrm{Lu}(0.69), \mathrm{HREY}(0.57)\end{array}$ & $\begin{array}{l}\mathrm{Li}(0.66), \mathrm{V}(0.58), \operatorname{La}(0.51), \operatorname{Pr}(0.59), \mathrm{Nd}(0.53) \text {, } \\
\operatorname{Dy}(0.62), \mathrm{Y}(0.59), \operatorname{LREY}(0.68) .\end{array}$ \\
\hline
\end{tabular}


a)

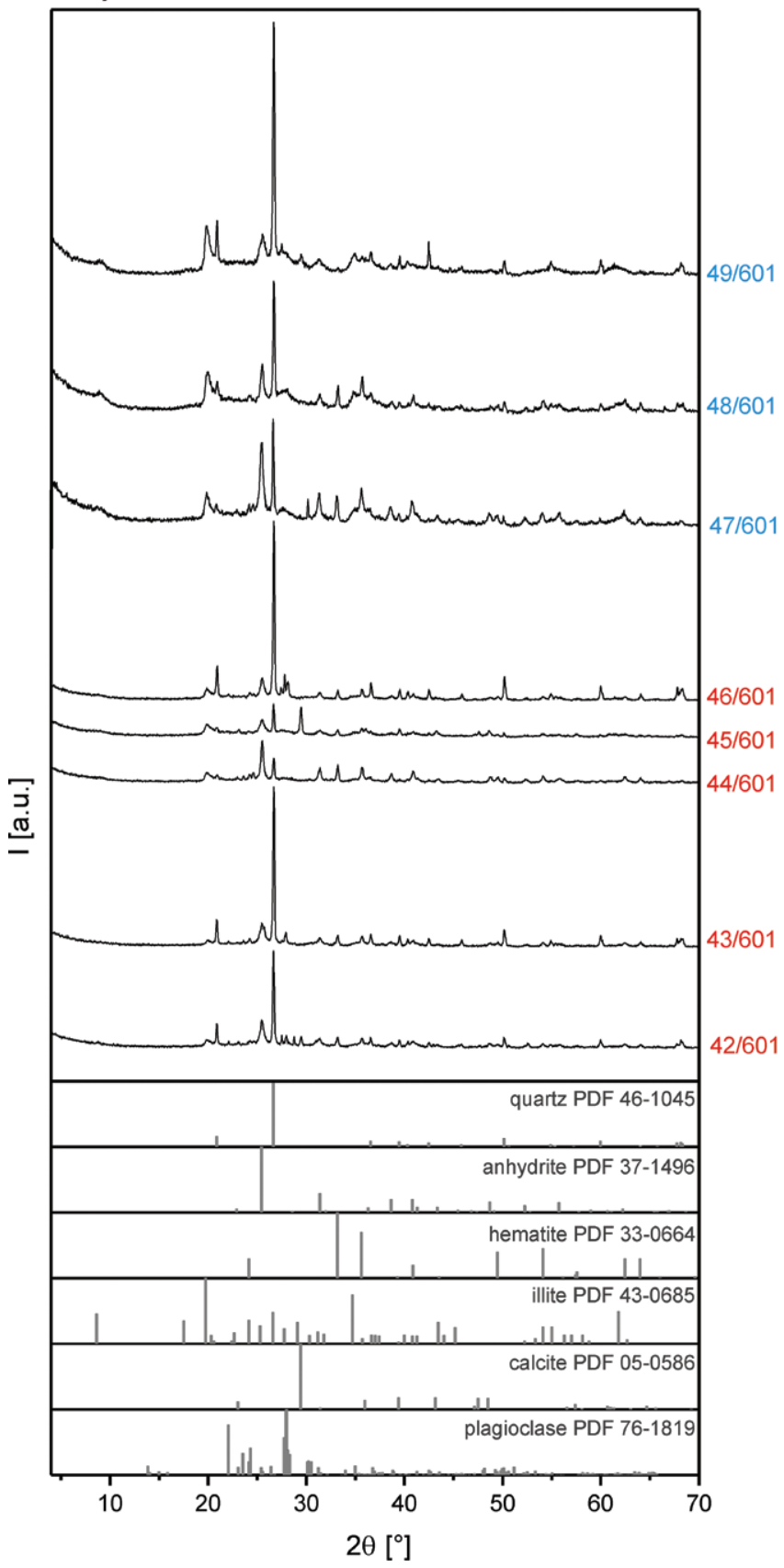

b)

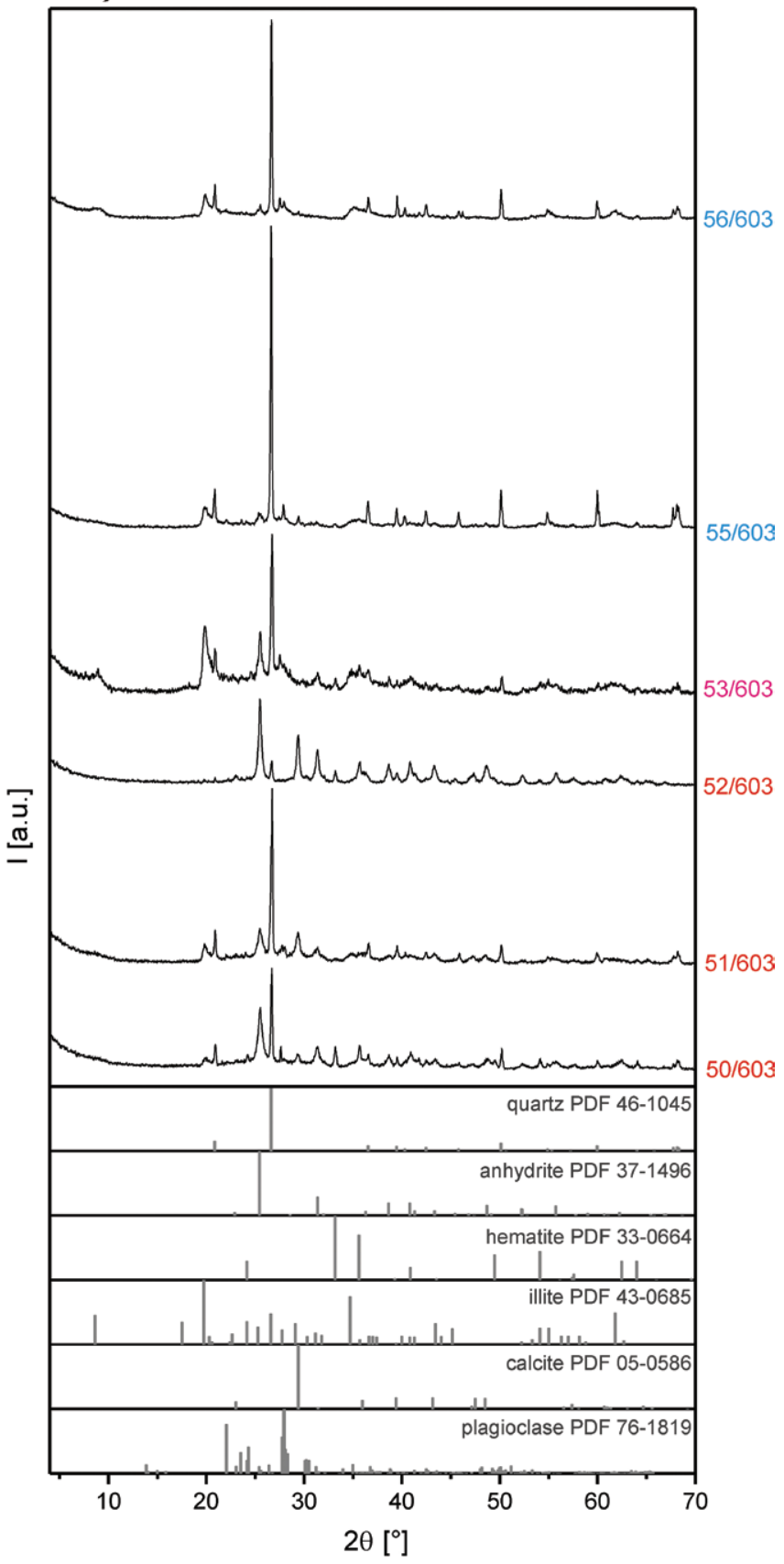

Figure S1. X-ray diffraction patterns of lignite ash $\left(450^{\circ} \mathrm{C}\right)$ of individual samples of boreholes GD-601 (a) and GD-603 (b) in the A field. 


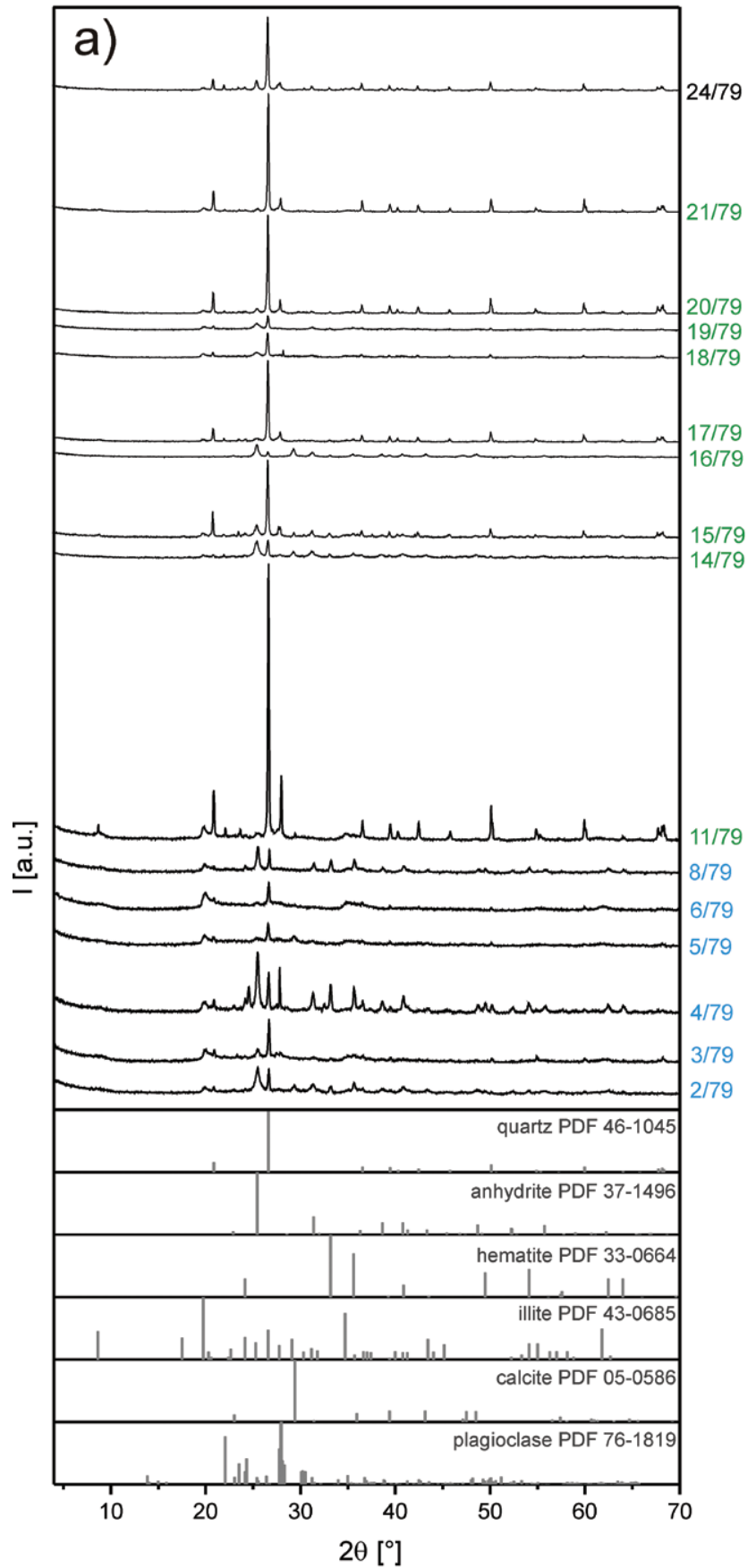

b)

$24 / 79$

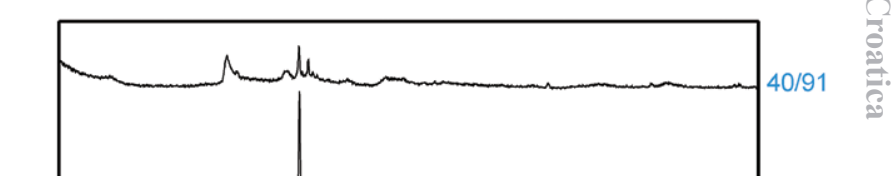

Figure S2. X-ray diffraction patterns of lignite ash $\left(450^{\circ} \mathrm{C}\right)$ of individual samples of boreholes KB-79 (a) and KB-91 (b) in the B field. 